\title{
33. LATE QUATERNARY PALEOCEANOGRAPHY IN THE EASTERN EQUATORIAL PACIFIC OCEAN FROM PLANKTONIC FORAMINIFERS: A HIGH-RESOLUTION RECORD FROM SITE $846^{1}$
}

\author{
J. Le, ${ }^{2}$ A.C. Mix,${ }^{3}$ and N.J. Shackleton ${ }^{2}$
}

\begin{abstract}
High-resolution records of $\delta^{18} \mathrm{O}$ and relative abundances of planktonic foraminifers were generated for ODP Leg 138 Site 846 for the past $800 \mathrm{k} . y$., with an average sampling interval of $3.6 \mathrm{k} . \mathrm{y}$. The time scale was constructed by correlating the benthic $\delta^{18} \mathrm{O}$ record to the SPECMAP and ODP Site $677 \delta^{18} \mathrm{O}$ time scales using the mapping function technique of Martinson et al. (1981). Our observations show that variations in the foraminiferal assemblages, although influenced by dissolution, are interpretable in terms of changing characteristics of upper ocean waters.

Carbonate dissolution as indicated by fragmentation of planktonic foraminifers shows concentrated variance that is coherent with $\delta^{18} \mathrm{O}$ at the 100 and $41 \mathrm{k} . \mathrm{y}$. orbital periods. At these periods, maximum dissolution occurs during interglacial extremes. This finding differs from previous studies that have indicated that in this region percent carbonate minimum lags global ice volume minimum.

$N$. dutertrei and dextral $N$. pachyderma dominate the assemblages, but do not show consistent relationships relative to glacial-interglacial cycles. However, less abundant species $G$. ruber, G. menardii, G. glutinata and $G$. sacculifer show positive and $G$. bulloides negative correlation with the $\delta^{18} \mathrm{O}$ record. Q-mode factor analysis of the Site 846 assemblages and comparison with modern assemblages suggest the following. Prior to and during interglacials, the area was considerably warmer and more subtropical than at present; during glacials, the area was colder than at present with greater upwelling and advection off the eastern boundary, and possibly a stronger Peru Current; the equatorial "cool tongue" was also possibly stronger.
\end{abstract}

\section{INTRODUCTION}

A major objective of ODP Leg 138 was to study the history of the equatorial circulation in the eastern Pacific Ocean. A large proportion of such information is contained in microplankton fossil assemblages in deep-sea sediments. For example, species compositions of planktonic foraminiferal assemblages reflect the conditions of surface waters in which they lived; the preservation status of the fossil is indicative of seawater chemistry and/or productivity level at the time. In the eastern equatorial Pacific Ocean, foraminifers have been partially dissolved in most areas as a result of the shallow carbonate lysocline (Adelseck and Anderson, 1978); as a result, previous paleoceanographic studies in the area that used fossil assemblage data are mostly based on radiolarians (Romine, 1982; Schramm, 1985; Hays et al., 1989). However, the moderate preservation of planktonic foraminifers at Site 846 provides a good opportunity for paleoceanographic studies using foraminiferal assemblages, thus providing independent evaluation of the results of radiolarian studies.

\section{REGIONAL OCEANOGRAPHIC SETTING}

Site 846 was drilled at $3^{\circ} 5.7^{\prime} \mathrm{S}, 90^{\circ} 49.08^{\prime} \mathrm{W}$, at a water depth of $3307 \mathrm{~m}$ (Fig. 1). It is located at the eastern end of the South Equatorial Current (SEC) and the northern end of the Peru Current and was designed to examine the history of the Peru Current and its interaction (or lack thereof) with the SEC. Figure 1 shows a generalized surface circulation pattern of the eastern equatorial Pacific Ocean. The circulation is dominated by the eastern and equatorial parts of two anticyclonic gyres, the California Current and the North Equatorial Current (NEC) in the North, and the Peru Current and the South Equatorial Current (SEC) in the South Pacific Ocean. Between them is the

'Pisias, N.G., Mayer, L.A., Janecek, T.R., Palmer-Julson, A., and van Andel, T.H (Eds.), 1995. Proc. ODP, Sci. Results, 138: College Station, TX (Ocean Drilling Program)

${ }^{2}$ University of Cambridge, Godwin Laboratory, Free School Lane, Cambridge CB2 3RS, United Kingdom.

${ }^{3}$ College of Oceanography, Oregon State University, Corvallis, OR 97331, U.S.A. eastward-flowing Equatorial Countercurrent (ECC). The SEC extends across the equator to about $5^{\circ} \mathrm{N}$, bordering with the ECC, and its southern boundary is approximately at $10^{\circ} \mathrm{S}$ (Wyrtki, 1966, 1981).

The equatorial current system is driven by the trade winds in the region. Seasonal variations of the NEC and ECC are influenced by the position of the northeast trade winds, rather than by their strength. During the Northern Hemisphere summer when the northeast trade winds reach their northernmost position, the NEC and ECC are both intensified. Unlike the NEC and ECC, seasonal variations of the SEC follow the strength of the southeast trade winds, which are most intense during the Southern Hemisphere winter. At the same season, the equatorial upwelling is also intensified.

A prominent oceanic feature in the eastern equatorial Pacific Ocean is the existence of a tongue of cool water. Wyrtki (1981) suggested, based on heat budgets, that most of the Equatorial Pacific Cool Tongue reflects shallow upwelling out of the upper portions of the eastward-flowing Equatorial Undercurrent ( $>20^{\circ} \mathrm{C}$ water), although a portion could result from the advection off the eastern boundary. Bryden and Brady (1985) emphasized eastward and upward flow along the outcropping isopycnals, with sources somewhat deeper than those predicted by Wyrtki (1981). This implies that the Cool Tongue reflects basin-scale thermocline and sea-level structure, rather than cross-isopycnal upwelling, in response to local winds. Toggweiler et al. (1991) argued that much of the SEC includes radiocarbon-depleted water that originates in the subantarctic Pacific. They believed that this water transits eastward in the lower part of the Equatorial Undercurrent (as $11^{\circ}-14^{\circ} \mathrm{C}$ water) before upwelling off Peru and advecting westward into the SEC. At present, both radiocarbon and heat budget considerations suggest that northward advection of cool surface water in the eastern boundary current is not important in setting the characteristics of water in the SEC of the Pacific Ocean.

Site 846 , at $3^{\circ} \mathrm{S}$, is probably far enough off the equator that it is not very sensitive to true equatorial upwelling, which only occurs within a couple degrees of the equator (Wyrtki, 1981; Philander, 1990). Instead, it is probably sensitive to a combination of (1) westward advection of recently upwelled water off the eastern boundary and (2) outcropping of cool isopycnals associated with the intensities of large-scale tropical Pacific circulation. 


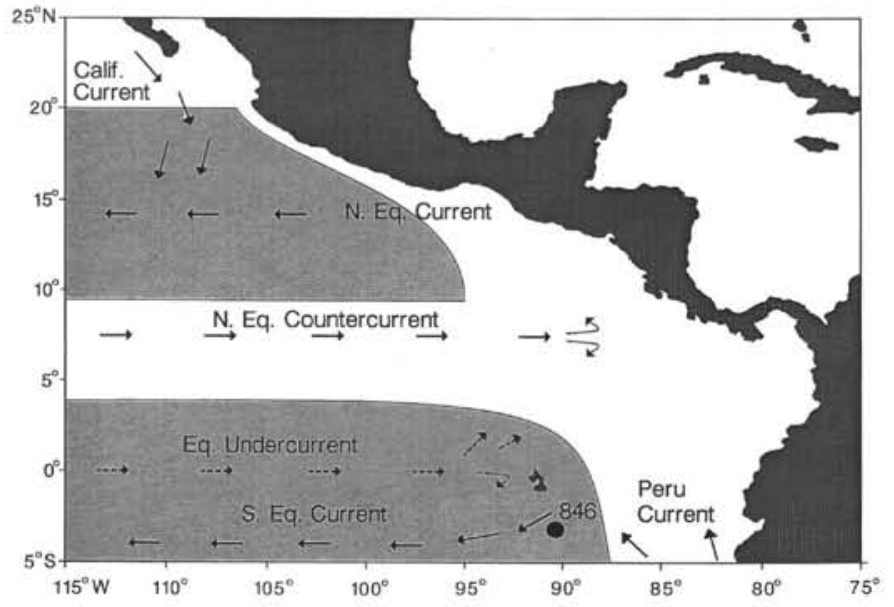

Figure 1. Site location and generalized surface circulation system in the equatorial Pacific Ocean. Surface current shown as solid arrow and subsurface current as dashed arrows.

\section{SAMPLE PREPARATION}

A high-resolution sequence of samples covering the last 800 k.y. was spliced together from Holes $846 \mathrm{~B}, 846 \mathrm{C}$, and $846 \mathrm{D}$ on the basis of the composite depth (Shipboard Scientific Party, 1992). The composite sections were constructed by detailed correlation of the records of gamma-ray attenuation porosity evaluation (GRAPE) records, magnetic susceptibility, and reflectance spectroscopy of the sediments from different holes at a resolution of 2 to $4 \mathrm{~cm}$ (Hagelberg et al., 1992). The average sampling interval for this foraminiferal study is $10 \mathrm{~cm}$, which yields an average time spacing of $3.6 \mathrm{k} . \mathrm{y}$. per sample.

The sediment samples were processed using standard procedures (Imbrie and Kipp, 1971). All samples except those from Section 138$846 \mathrm{~B}-2 \mathrm{H}-3$ to $-2 \mathrm{H}-4$ and Section $846 \mathrm{C}-2 \mathrm{H}-2$ to $-2 \mathrm{H}-3$ were processed at the Godwin Laboratory of the University of Cambridge. Samples were washed using distilled water through $150 \mu \mathrm{m}$ sieves, then fine and coarse fractions were dried in an oven at $60^{\circ} \mathrm{C}$ and weighed separately. The other set of samples was processed at Oregon State University. At OSU, samples were first freeze-dried, washed through $125 \mu \mathrm{m}$ sieves, and then dry-sieved through $150 \mu \mathrm{m}$ sieves. Experiments with freezedrying show that the fragmentation of foraminiferal tests does not change. Observation of samples was performed in the $>150 \mu \mathrm{m}$ size fraction. The coarse fraction was split using a Soiltest CL-242A microsplitter as many times as required to get a subsample of approximately 300 whole foraminiferal specimens. All whole, or essentially whole, specimens in the final split were identified and counted following the taxonomy used by the CLIMAP project (Kipp, 1976; CLIMAP, 1981). All benthic foraminifers were placed into one group, and the ratio of benthic foraminifers to the benthic plus planktonic foraminifers was calculated. The number of fragments also was counted. A fragmentation index is calculated as

$$
\text { Frag. Index }=\frac{\mathrm{frag} / 8}{\text { frag } / 8+\text { whole }} \cdot 100 \% .
$$

The arbitrary number 8 is used to correct the nonlinearity inherent in the traditional calculation of fragmentation ratio, based on the observation that a whole foraminifer is likely to be broken into a number of fragments (Le and Shackleton, 1992). The traditional calculation of the fragmentation ratio, which divides the number of fragments by the number of fragments plus whole foraminifers, is oversensitive to light dissolution and insensitive to severe dissolution. For isotope analysis, Cibicides wuellerstorfi was selected from the $>150 \mu \mathrm{m}$ size fraction. When there were not enough $C$. wuellerstorfi in a sample, Uvigerina peregrina was picked from the same size fraction. Most of the $U$. peregrina samples were analyzed at the
Godwin Laboratory, University of Cambridge, using a VG Isotech PRISM mass spectrometer. The specimens were first cleaned using $10 \%$ hydrogen peroxide and an ultrasonic bath, then reacted with $100 \%$ orthophosphoric acid at $90^{\circ} \mathrm{C}$ using a VG Isocarb common acid bath system, and the released $\mathrm{CO}_{2}$ was analyzed. The results are reported in the international Pee Dee Belemnite (PDB) scale. The analytical precision was about $\pm 0.06 \%$. The $C$. wuellerstorfi samples were analyzed at the College of Oceanography at Oregon State University, using a Finnigan/MAT251 mass spectrometer. For detailed procedure, refer to Mix et al. (this volume). The $\delta^{18} \mathrm{O}$ data used in this study is reported in Mix et al. (this volume).

\section{RESULTS AND DISCUSSION \\ Oxygen Isotope Stratigraphy}

The oxygen isotope data are plotted vs. revised composite depth (RMCD) (Hagelberg et al., this volume) in Figure 2. The composite record was constructed by adding $\pm 0.64 \%$ to the $\delta^{18} \mathrm{O}$ values from $C$. wuellerstorfi to approximate the values from $U$. peregrina (Shackleton, 1974).

The age model was generated by correlating the composite record to the SPECMAP time scale (Imbrie et al., 1984) for the period younger than $600 \mathrm{ka}$, and to the ODP Site $677 \delta^{18} \mathrm{O}$ time scale (Shackleton et al., 1990) for the older period. To merge these two data sets, we first scaled the SPECMAP record, which was reported in variance units, to the same mean and variance as the Site 677 benthic record over the period from 0 to $700 \mathrm{ka}$, and then spliced the two records at $600 \mathrm{ka}$, where there is a perfect match of $\delta^{18} \mathrm{O}$ values. Correlation of the Site 846 benthic $\delta^{18} \mathrm{O}$ record to this reference record was accomplished using the quantitative mapping function technique of Martinson et al. (1981). To avoid falsely correlating noise, we constrained the correlation to produce sedimentation rates that vary smoothly, with no variations in sedimentation rate at periods shorter than 20 k.y.

Figure 3 illustrates the Site $846 \delta^{18} \mathrm{O}$ time series, together with the target $\delta^{18} \mathrm{O}$ time scale constructed from the SPECMAP and ODP Site 677 for comparison. Note that the Site $846 \delta^{18} \mathrm{O}$ record has only one lightest value at stage 17 , where Holes $846 \mathrm{C}$ and $846 \mathrm{D}$ were spliced together. The comparison of the GRAPE records of Holes 846B, 846C, and $846 \mathrm{D}$ suggests that sampling at stage 17 was not adequate. This interval is in Section 138-846D-3H-1, which contains a large vertical burrow visible in the core photograph (Mayer, Pisias, Janecek, et al., 1992). It appears that stage 17 interval may be better represented in Section 138-846C-3H-2, although this would need to be confirmed by further isotopic analysis. Because of the incomplete stage 17, all the time series analyses in this study use only the part of the time series that is younger than $663 \mathrm{ka}$, where there is a core break.

Cross-spectral analysis techniques have been applied to study the variance distribution in the frequency domain and phase relationships of various time series generated in this study (Jenkins and Watts, 1968). The time series were first interpolated at 3 k.y. intervals and analyses were performed on a series of 221 data points extending to $663 \mathrm{ka}$. For cross-spectral analysis, 75 lags were used, giving a bandwidth of $0.006 \mathrm{cycle} / \mathrm{k} . \mathrm{y}$. The phase ranges were calculated at the $95 \%$ confidence level; and in the phase plot, the phase angle is only shown at those frequencies at which coherency is significant.

The cross-spectrum shows that the Site $846 \delta^{18} \mathrm{O}$ time series contains concentrated variance in bands centered at the 100, 41, and 23 k.y. periods, and are highly coherent with target $\delta^{18} \mathrm{O}$ records (Fig. 4). The two time series are in phase with each other (Table 1). This suggests that the Site $846 \delta^{18} \mathrm{O}$ record was successfully correlated to the target $\delta^{18} \mathrm{O}$ time scale.

\section{Dissolution of Foraminifers}

Fragmentation of planktonic foraminiferal shells is a reliable indicator of the dissolution level that a foraminiferal assemblage has 


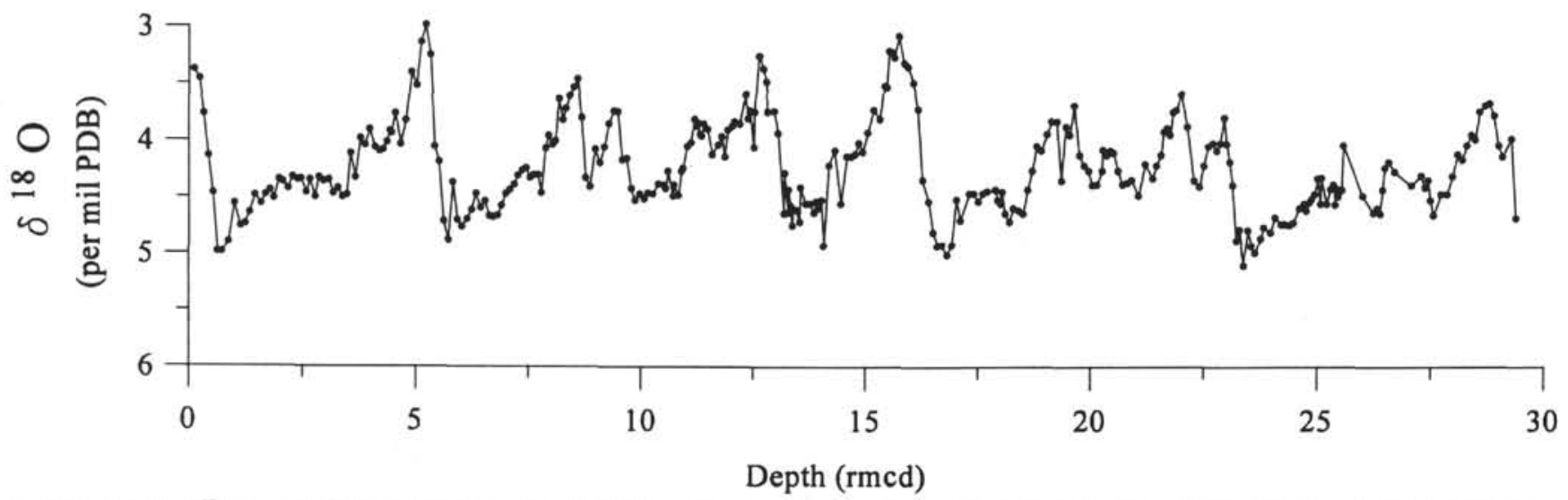

Figure 2. Site $846 \delta^{18} \mathrm{O}$ data plotted vs. rmcd. The composite $\delta^{18} \mathrm{O}$ record was constructed by combining $\delta^{18} \mathrm{O}$ data from different holes and by adding $+0.64 \%$ to the values of $\delta^{18} \mathrm{O}$ from $C$. wuellerstorfi to approximate $U$. peregrina $\delta^{18} \mathrm{O}$.

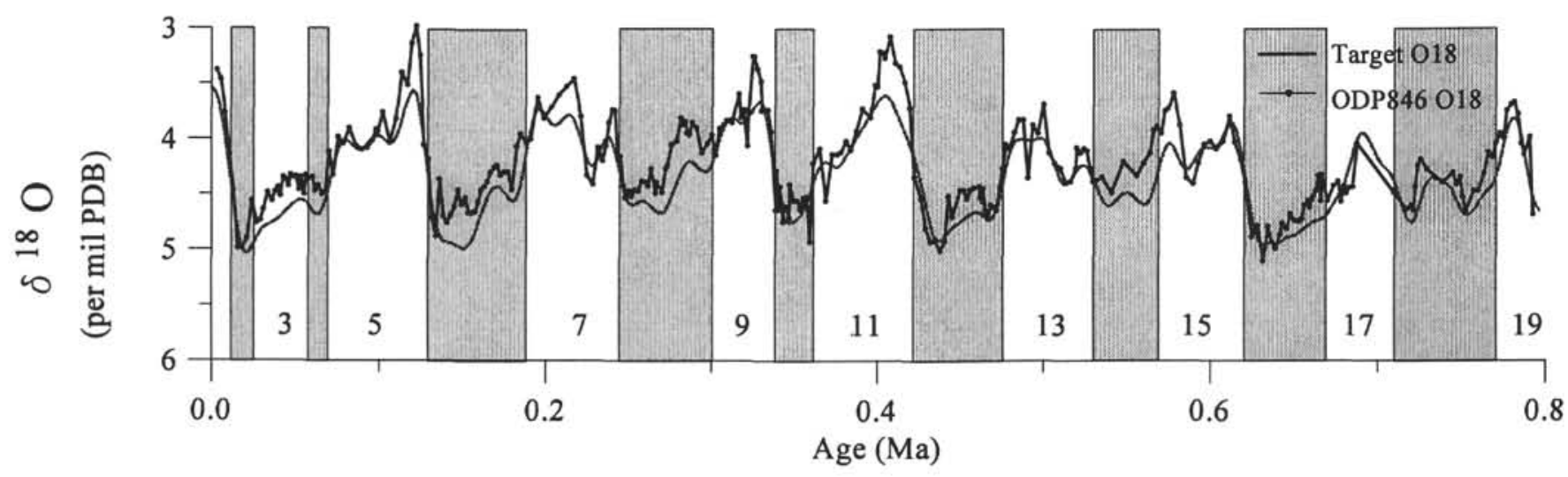

Figure 3. Site $846 \delta^{18} \mathrm{O}$ time series constructed by correlating to the SPECMAP $\delta^{18} \mathrm{O}$ time scale for the period younger than $600 \mathrm{ka}$ and to the ODP Site $677 \delta^{18} \mathrm{O}$ time scale for the older period. Shaded areas represent glacials.

experienced (Thunell, 1976; Le and Shackleton, 1992). Figure 5B illustrates the variations of the fragmentation index at Site 846. The average value of the fragmentation index is $9 \%$, and the 95 th percentile is $27 \%$. Fragmentation is usually greater during interglacial stages, generally consistent with normal Pacific dissolution patterns (Berger, 1973; Le and Shackleton 1992). Especially strong fragmentation events are evident during the mid-Brunhes period between 250 and $650 \mathrm{ka}$. At the most dissolved level at about $400 \mathrm{ka}$, as indicated by the maximal fragmentation, the assemblages are composed mostly of large specimens of $N$. dutertrei and $G$. menardii. The last two Holocene samples are also highly fragmented, consistent with the Holocene dissolution event in the Pacific Ocean (Keir and Berger, 1985). This late Holocene carbonate dissolution event is usually only seen in deep cores (Francois et al., 1990; Le and Shackleton, 1992).

The relative abundance of benthic foraminifers shows a fluctuation pattern similar to the fragmentation index at Site 846 (Fig. 5C). When there is little carbonate dissolution, the \%benthics may be indicative of the productivity of overlying surface waters, because benthic foraminifers are more sensitive to changes in productivity than are planktonic foraminifers (Berger and Diester-Haass, 1988; Herguera and Berger, 1991). On the other hand, benthic foraminifers are more resistant to carbonate dissolution than are planktonic foraminifers, when carbonate dissolution becomes severe enough to largely increase the original relative abundance of benthic foraminifers by dissolving a large number of planktonic foraminifers, the resultant \%benthics may indicate dissolution, rather than productivity. Although neither index is a strictly quantitative measure of carbonate dissolution, the existence of a similar signal in both \% benthics and the fragmentation index is consistent with the stronger dissolution events during interglacial intervals.
Table 1. Results of cross spectral analyses.

\begin{tabular}{|c|c|c|c|c|c|c|}
\hline \multirow[b]{2}{*}{$X-Y$} & \multicolumn{2}{|c|}{100 k.y. } & \multicolumn{2}{|c|}{41 k.y. } & \multicolumn{2}{|c|}{23 k.y. } \\
\hline & $\emptyset$ & k & s & k & $\emptyset$ & k \\
\hline$\delta^{18} \mathrm{O}_{\text {spec }}$ vs. $\delta^{18} \mathrm{O}_{\mathrm{x}-16}$ & $5 \pm 10$ & 0.98 & $2 \pm 11$ & 0.98 & $4 \pm 7$ & 0.99 \\
\hline$-\delta^{1 \mathrm{x}} \mathrm{O}_{\mathrm{x} 46}$ vs. fragment & $-9 \pm 23$ & 0.89 & $13 \pm 27$ & 0.86 & & $\mathrm{NC}$ \\
\hline$-\delta^{18} \mathrm{O}_{846}$ vs. \%benthics & $15 \pm 20$ & 0.92 & & $\mathrm{NC}$ & & $\mathrm{NC}$ \\
\hline$-\delta^{1 \mathrm{x}} \mathrm{O}_{x+6}$ vs. factor 1 & & $\mathrm{NC}$ & & $\mathrm{NC}$ & & $\mathrm{NC}$ \\
\hline$-\delta^{18} \mathrm{O}_{846}$ vs. factor 2 & $-30 \pm 19$ & 0.93 & $-18 \pm 25$ & 0.88 & & $\mathrm{NC}$ \\
\hline$-\delta^{1 \mathrm{x}} \mathrm{O}_{846}$ vs. factor 3 & $160 \pm 17$ & 0.92 & & $\mathrm{NC}$ & & NC \\
\hline
\end{tabular}

Notes: Time step used $=3 \mathrm{k} . y$. . number of lags $=75$, which gives a bandwidth of 0.006 cycle/k.y. Phase ranges were calculated at $95 \%$ confidence levels. Positive angle implies that $X$ leads $Y . \mathrm{NC}=$ not coherent.

Cross-spectral analysis was performed between the $-\delta^{18} \mathrm{O}$ and fragmentation index and \% benthics to study their cyclicities and phase relationships. Results show that the power spectrum of fragmentation time series is dominated by variance at the 100 k.y. eccentricity and $41 \mathrm{k} . \mathrm{y}$. obliquity bands (coherency $=0.89,0.86$, respectively; Fig. 6A). The variance concentration at the 23 k.y. precession band is also significant; it is, however, not coherent with $-\delta^{18} \mathrm{O}$ at $80 \%$ confidence level. Fragmentation maxima are approximately in phase with ice volume minima at the periods of 100 and 41 k.y.

The phase relationships between fragmentation and the global ice volume at Site 846 differ from those in the western equatorial Pacific Ocean. In a western Pacific core, RC17-177 $\left(1^{\circ} 14.5^{\prime} \mathrm{S}, 157^{\circ} 00.5^{\prime} \mathrm{E}\right.$, $2600 \mathrm{~m}$ water depth), fragmentation maxima significantly lag ice volume minima $\left(77 \pm 13^{\circ}\right.$ at 100 k.y., $85 \pm 40^{\circ}$ at 41 k.y., and $115 \pm$ 

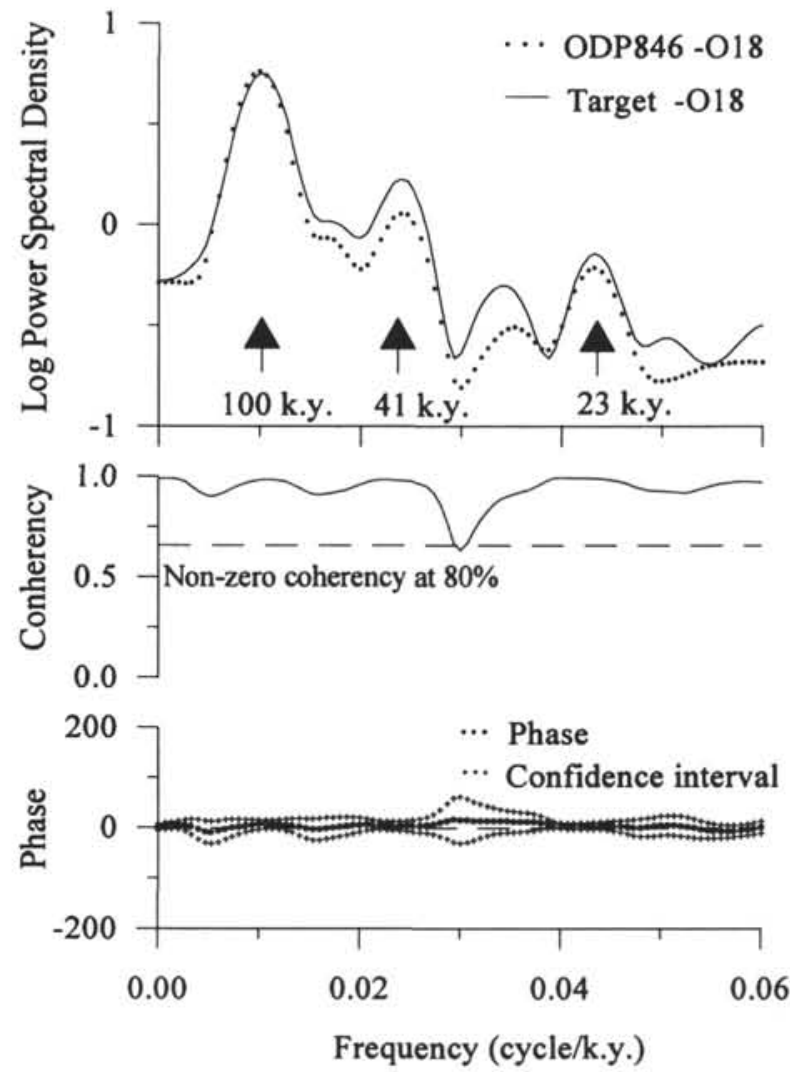

Figure 4. The cross spectrum between the SPECMAP and Site $846 \delta^{18} \mathrm{O}$ time series for the last $663 \mathrm{ka}$. The time step is $3 \mathrm{k} . \mathrm{y}_{\text {., }}$ and 75 lags were used. The phase ranges were calculated at $95 \%$ confidence level.

$28^{\circ}$ at $23 \mathrm{k} . y$. at the $95 \%$ confidence level). ERDC-93P ( $1619 \mathrm{~m}$ water depth) and V28-238 (3120 m water depth), which are adjacent to RC17-177, have phase relationships similar to those of RC17-177. Note that the seawater carbonate chemistry and productivity are different in two areas. The lysocline progressively shoals to the east in response to greater organic carbon input associated with increased surface productivity. In the western equatorial Pacific Ocean, above the Ontong Java Plateau, the lysocline was mapped between $3400 \mathrm{~m}$ (Berger et al., 1982) and $3500 \mathrm{~m}$ (Valencia, 1977). In the eastern equatorial Pacific Ocean, over the western flank of the East Pacific Rise, the lysocline lies at about $3200 \mathrm{~m}$ (Adelseck and Anderson, 1978). Whether the differences in the phase relationships are caused by the fact that Site 846 is near the present lysocline in the area and those western Pacific cores are above the lysocline remains to be seen.

The \%benthics contains concentrated variance at the 100 k.y. eccentricity band (Fig. 6B). It leads ice volume minima by $15 \pm 20^{\circ}$, thus is approximately in phase with ice volume minima. This phase relationship is similar to that of fragmentation index at the 100 k.y. cycle. However, \%benthics does not show significant variance at the 41 k.y. tilt and 23 k.y. precession cycles; instead, it contains significant variance near periods of 46 and $33 \mathrm{k}$.y. The power spectrum suggests that the \%benthics of Site 846 mainly responded to deep-sea dissolution rate, but was also influenced by other factors, perhaps organic carbon flux from surface waters.

\section{Faunal Variations of Planktonic Foraminifers}

A total of 239 samples were analyzed in terms of species compositions, with an average of 390 specimens per sample. The relative abundance data of the planktonic foraminiferal species are listed in the Appendix. Table 2 contains the descriptive statistics of these species in comparison with the same species of those Pacific core-top samples that are distributed to the east of $180^{\circ}$ longitude (Prell, 1985). In Figure 7 , the variations of the relative abundances of the 10 most abundant species have been plotted vs. age. The time series of $\delta^{18} \mathrm{O}$ and fragmentation index are also plotted in the top panel for comparison. Of these 10 species, seven have average relative abundances above $2 \%$. In the order of decreasing average percentages, these are Neogloboquadrina dutertrei, Globigerina bulloides, Neogloboquadrina pachyderma (right-coiling), Globorotalia menardii, Globigerinita glutinata, Globigerinoides ruber, and Orbulina universa, together constituting approximately $94 \%$ of the total planktonic foraminiferal census count. Overall, the relative abundances of these species fluctuate with greater amplitudes between 250 and $650 \mathrm{ka}$, the so-called mid-Brunhes dissolution event, than during the last $200 \mathrm{k} . y .$, probably as a result of strong carbonate dissolution.

Together, N. dutertrei and dextral N. pachyderma account for $69 \%$ of the planktonic foraminifer census count, dominating the foraminiferal assemblages at Site 846 (Fig. 7A). N. dutertrei shows the greatest downcore variations among all the species, as indicated by its standard deviation (Table 2). $N$. dutertrei and $N$. pachyderma (rightcoiling) display large morphological variations in different parts of the oceans; a variety of transitional forms exist between typical specimens of $N$. dutertrei and $N$. pachyderma (right coiling) (Kennett, 1976). To represent those intermediate forms between $N$. dutertrei and dextral $N$. pachyderma, "P-D intergrade" was used in the CLIMAP project (Kipp, 1976; CLIMAP, 1976). However, separation of "P-D intergrade" from $N$. dutertrei and dextral $N$. pachyderma has also been difficult, and its use remains controversial. Because this taxon was not used in the Pacific core-top foraminifer identifications (Parker and Berger, 1971; Prell, 1985), this study only calculates the percentages of $N$. dutertrei and dextral $N$. pachyderma. "P-D intergrade" was lumped into $N$. dutertrei, which therefore in this study includes the typical large specimens of $N$. dutertrei and a large number of "P-D intergrade." Observation of the compositions of $N$. dutertrei and $N$. pachyderma (right-coiling) shows noticeable variations through glacial and interglacial cycles resulting from dissolution and/or ecological effects. The more dissolved interglacial samples tend to contain more large specimens of $N$. dutertrei, whereas better preserved glacial samples tend to contain more small specimens. This phenomenon is most evident as the low abundance of $N$. dutertrei and $N$. pachyderma during the mid-Brunhes most dissolved period at about $400 \mathrm{ka}$, when only a small number of large specimens of this group remain. $N$. pachyderma tends to show higher abundances during glacials except stage 4 .

G. menardii shows fluctuation patterns that are remarkably similar to both the fragmentation index and the $\delta^{18} \mathrm{O}$ records (Fig. 7A). This species shows stronger positive correlation with the fragmentation index than $N$. dutertrei, which is regarded as more dissolution-resistant than G. menardii (Parker and Berger, 1971). This is because " $N$. dutertrei" in this study contains a large proportion of small "P-D intergrade," which is dissolution susceptible; as a result, "N. dutertrei" in this study becomes less dissolution-resistant as a whole group than G. menardii. In the Pacific Ocean, maximal abundances of this species occur in places where sea surface temperatures (SST) are between $26^{\circ}$ to $28^{\circ} \mathrm{C}$ (Prell, $1985 ; \mathrm{Le}, 1991$ ). At Site 846 , the present SST ranges from $21^{\circ} \mathrm{C}$ in September to $27^{\circ} \mathrm{C}$ in March (Halpern et al., 1990); therefore, higher abundances of $G$. menardii during interglacials probably implies that SST was higher during interglacials than during glacials. However, caution should be excercised, because the maximal abundances of this species during the mid-Brunhes dissolution period suggest that the abundance of $G$. menardii was also influenced by dissolution at Site 846 . Note that if ecological factors produced more G. menardii during interglacials than during glacials as a result of higher temperatures, dissolution and temperature would affect the relative abundances of $G$. menardii in the same direction, since dissolution was stronger during interglacials.

$G$. ruber, G. sacculifer, and $G$. glutinata generally have abundances below $10 \%$ at Site 846 . Although in low abundances, these 


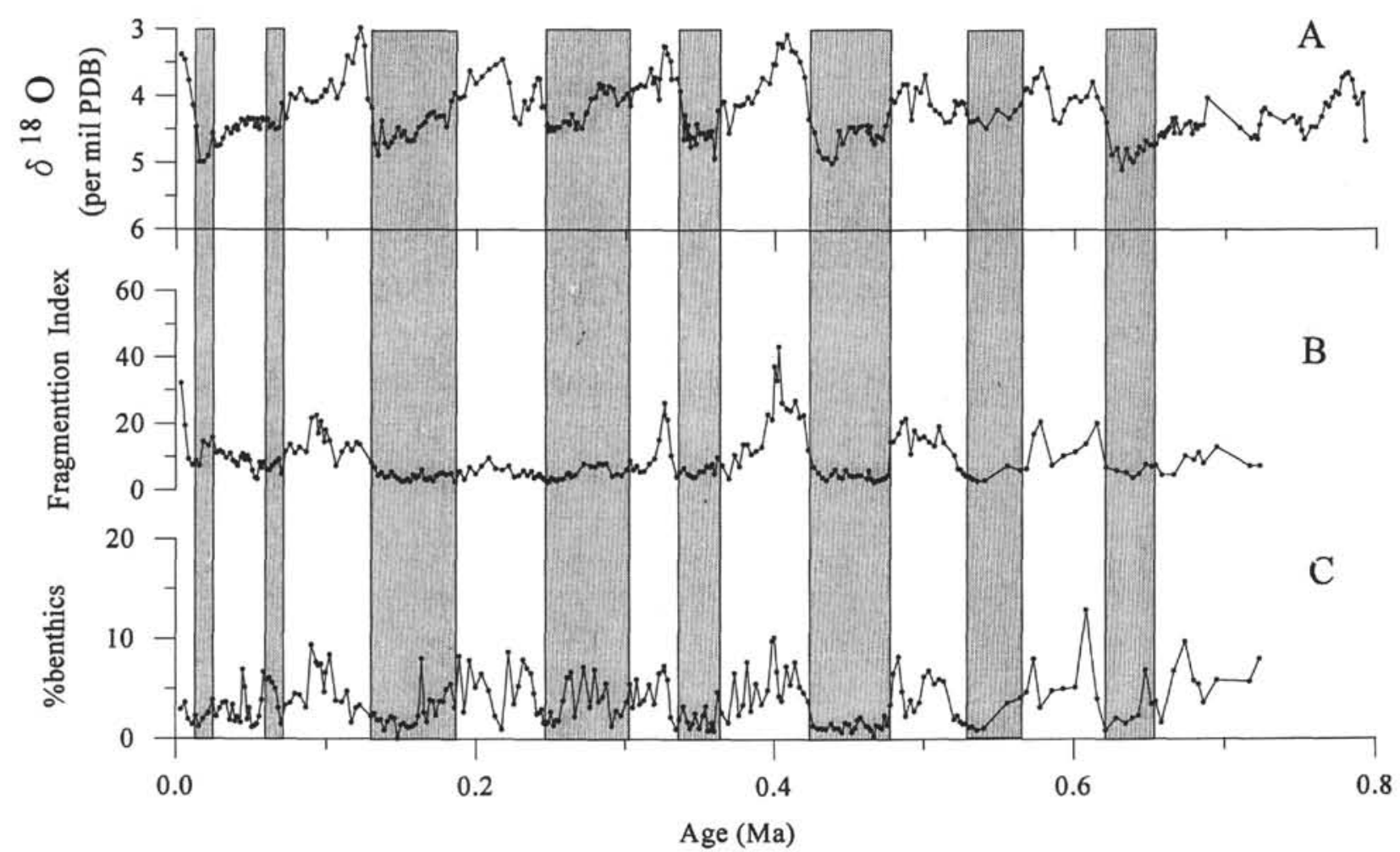

Figure 5. Time series of fragmentation index (B), and \%benthics (C). The \%benthics is calculated as the number of benthic foraminifers divided by the number of benthic plus planktonic foraminifers. For the calculation of the fragmentation index, see text. The Site $846 \delta^{18} \mathrm{O}$ time series is plotted for comparison (A). The shaded areas represent glacial stages.
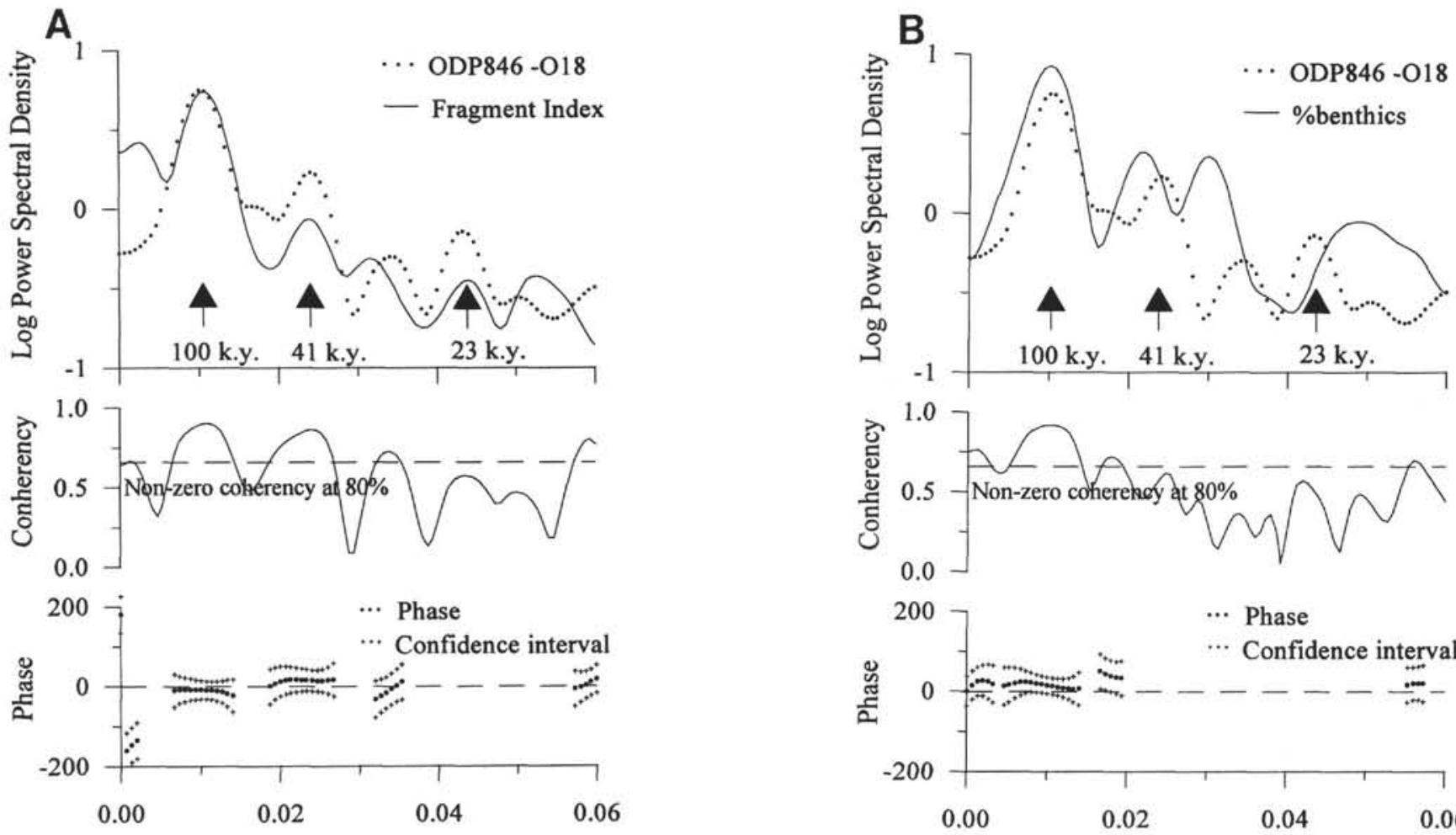

Frequency (cycle/k.y.)

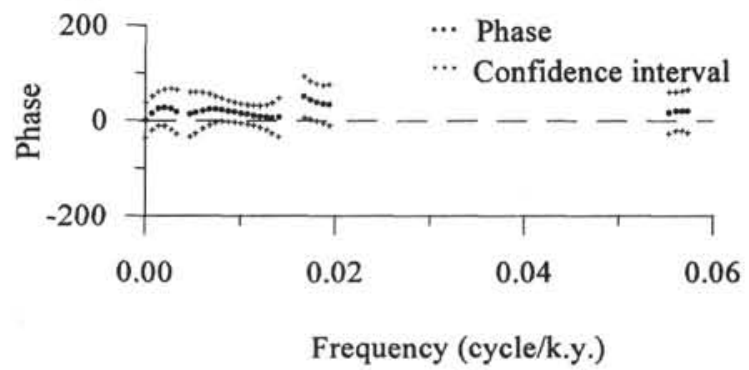

Figure 6. The cross spectrum between the time series of Site $846-\delta^{18} \mathrm{O}(\mathbf{A})$ and fragmentation and \%benthics (B). The values of fragmentation index and \%benthics have been scaled so that their power spectra can be displayed on the scale as that of $\delta^{18} \mathrm{O}$. The parameters for cross spectral analyses are the same as those in Figure 4. A positive phase angle indicates that ice volume minima lead fragmentation maxima. For numerical value of the phases and coherencies, see Table 1. 


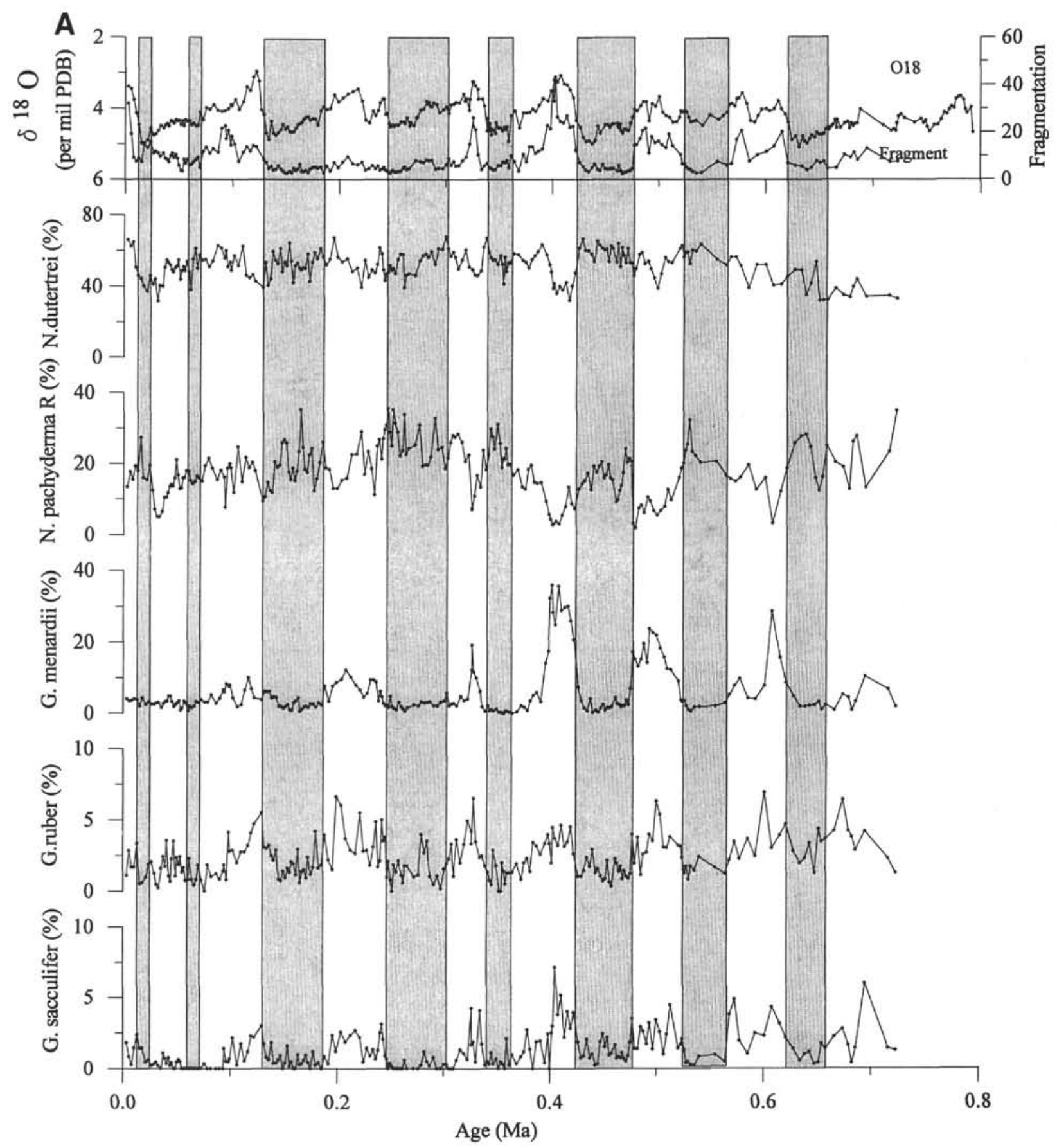

Figure 7. A, B. Relative abundances of 10 abundant planktonic foraminifers species at Site 846 . The Site $846 \delta^{18} \mathrm{O}$ and fragmentation time series are plotted in the top panel for comparison. The shaded areas represent glacial stages.

species show systematic variation patterns with higher abundances during interglacials, thus having positive correlation with the fragmentation index (Figs. 7A and 7B). This is surprising, because these species are especially sensitive to dissolution (Parker and Berger, 1971) and should have been less abundant in more dissolved samples if dissolution was the dominant control factor. However, the maximum abundances of these three species occur in the area where the winter SSTs are about between $25^{\circ}$ and $28^{\circ} \mathrm{C}$ in the Pacific Ocean (Prell, 1985; Le, 1991 ), whereas the present SST at Site 846 ranges from $21^{\circ}$ in September to $27^{\circ} \mathrm{C}$ in March (Halpern et al., 1990). Therefore, the higher abundance of these species during interglacial episodes may indicate warmer, more subtropical conditions (consistent with CLIMAP 1981).
In addition, since the rate of dissolution at the seafloor was greater during interglacial time, these fragile species would be under-represented in the sediment record relative to their upper ocean production, and we would underestimate the extent of climate change. The above discussion suggests that the positive correlation between fragile planktonic species and fragmentation is fortuitous and driven by different processes (upper ocean warming bringing in warm species, deep ocean chemistry controlling dissolution rate).

Higher abundances of $G$. ruber, G. glutinata and G. sacculifer in the interglacial samples raise the concern that the higher interglacial fragmentation may be caused by the greater fraction of fragile species reaching the seafloor. In this case, it is possible that there was no 

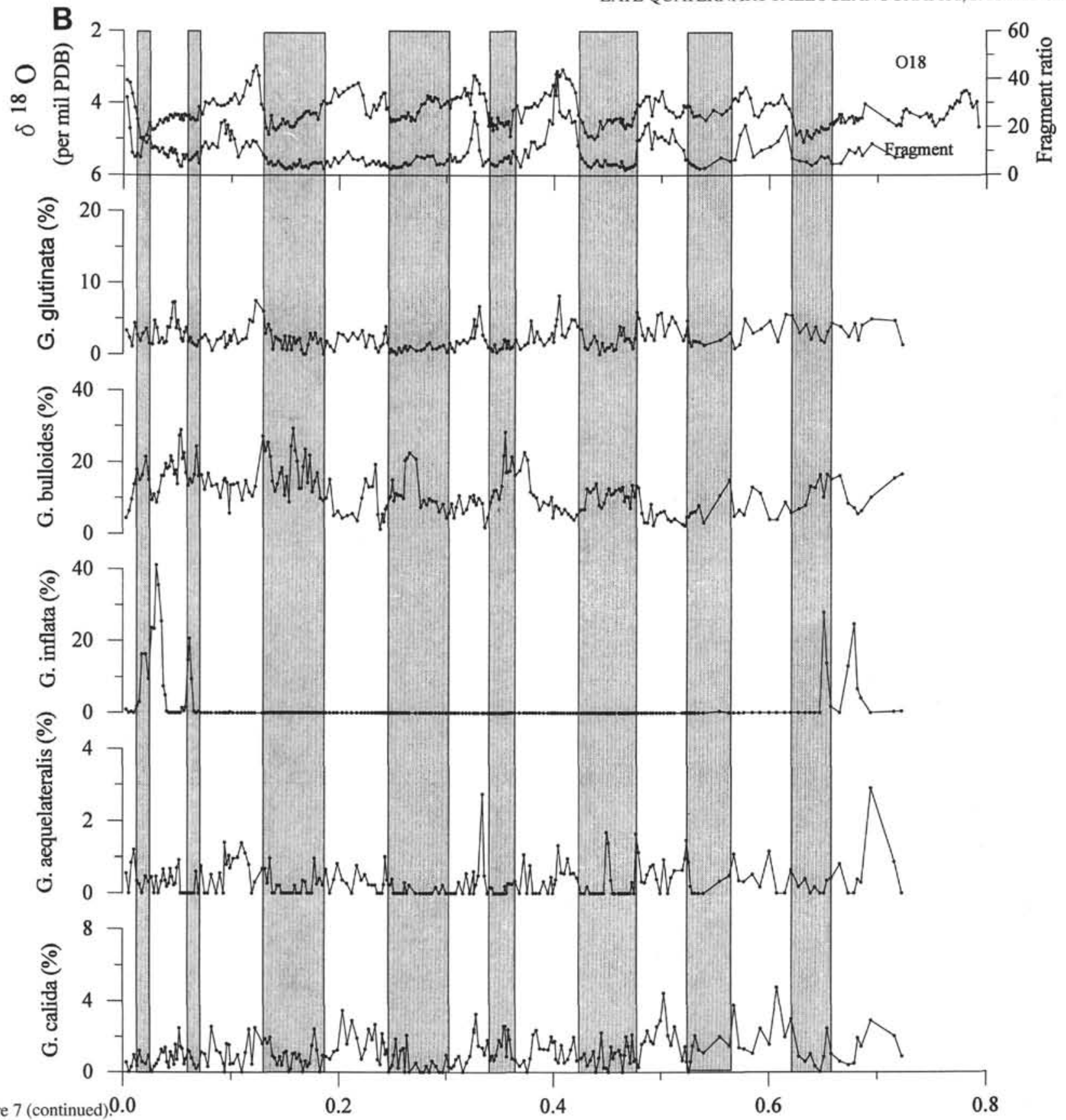

Figure 7 (continued) 0.0

0.2

Age (Ma)

change in the deep-sea dissolution rate, and the apparent fragmentation record would have been driven by upper-ocean ecology. However, considering other evidence for wide-spread dissolution in interglacial episodes in the Pacific Ocean (Farrell and Prell, 1989; Le and Shackleton, 1992), the generally low abundance of these species and our observation that G. ruber and G. sacculifer in interglacial samples are more thick-walled, robust specimens that are more likely to preserve well, we believe that changing dissolution rates in the deep sea are at least part of the story.

G. bulloides averages approximately $12 \%$ with maximal values of about 29\% (Fig. 7B). This species tends to show higher abundances during glacial periods than during interglacial periods; and in the last Holocene sample, it has an abundance of $4.4 \%$.

$G$. inflata shows several distinctive spikes during oxygen stage boundaries $3 / 2,4 / 3,17 / 16$, and $18 / 17$. This species was also abundant during stage 2 . Despite its maximal abundance reaching $40 \%$, this species was generally absent during most periods of the time under study. This pattern was also found in other cores in the eastern equa-

torial Pacific Ocean (McKenna at el., this volume; A. Mix, unpubl. data). The reasons why $G$. inflata exhibits sudden abundance spikes during some glacial-interglacial transitions and glacials, but not others, need further investigation.

\section{Q-mode Factor Analysis}

To simplify the faunal variations at Site 846, Q-mode factor analysis was used. Q-mode factor analysis resolves each fossil assemblage into a proportional combination of a smaller number of independent end-members (i.e., factors); each factor is in turn a linear combination of input species. The importance of a factor in describing an assemblage is indicated by a factor loading, and the importance of a species in a factor is indicated by a factor score. In studies such as CLIMAP, Q-mode factor analysis is first used to resolve Holocene fossil assemblages into factors that are then calibrated against a modern oceanic variable to establish a transfer function. Then, core samples representing the geological past are reconstructed in terms of these modern 
Table 2. Descriptive statistics for planktonic foraminifers from Site 846 and from core-top samples in the eastern equatorial Pacific Ocean.

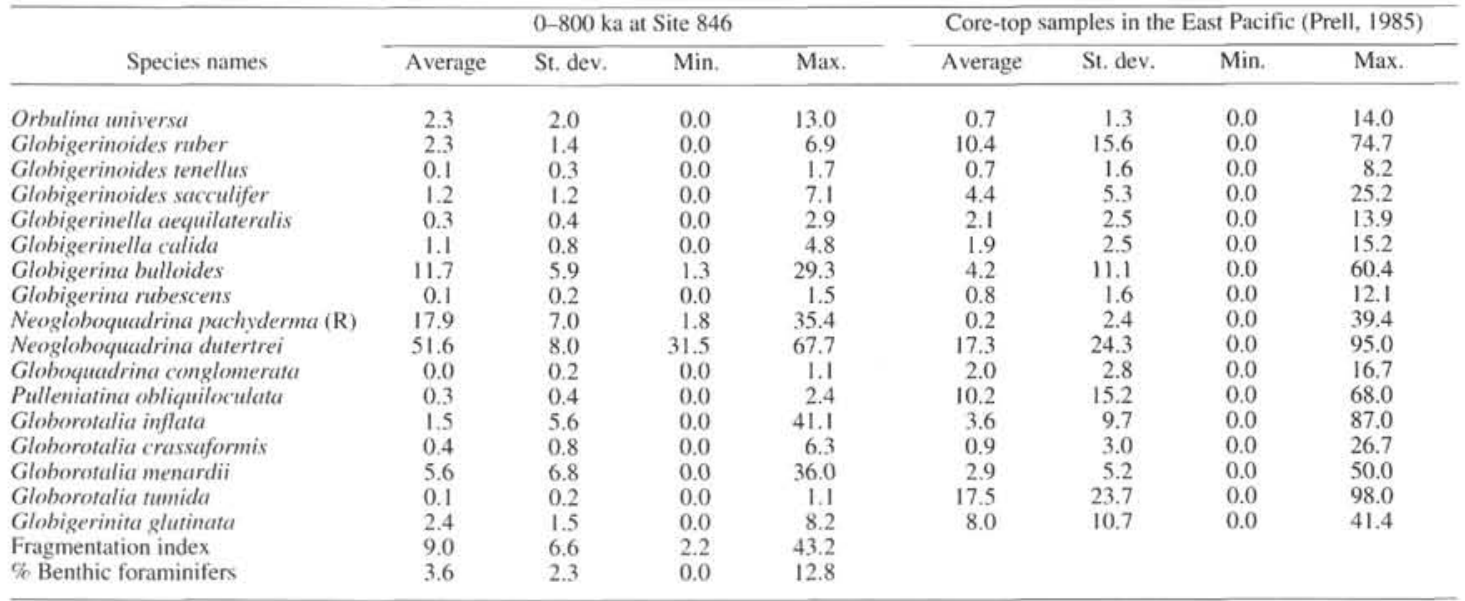

factors, and the transfer function is used to estimate the value of the oceanic variable (Imbrie and Kipp, 1971; CLIMAP, 1981; Le, 1991). A reliable foraminiferal transfer function is yet to be developed for the use in the east Pacific Ocean. Here, we focus on analyzing the faunal variations at Site 846, and then we look for the sources of influences on the Site 846 faunas from the modern fossil assemblage distribution. If factors defined from downcore species counts yield interpretable ecological assemblages present in the modern core-top samples, then this method points to watermass variations responsible for the past changes in fauna. We found this direct application of factor analysis to the Site 846 faunal data to be more interpretable than the more traditional projection of modern core-top faunal factors onto downcore faunas.

Another difference in the use of Q-mode factor analysis in this study is that the species abundances of Site 846 that are input to the factor analysis are expressed in terms of the total observed range using the following range transformation:

$$
y=\frac{x-x_{\min }}{x_{\max }-x_{\min }},
$$

where

$x$ is the species percentage in a sample;

$x_{\min }$ and $x_{\max }$ are the minimum and maximum percentages of the species in the whole sample set; and

$y$ is the range-transformed species abundance that is then subjected to Q-mode factor analysis.

The purpose of the range transformation is to give each species equal weight in the factor analysis. Experiments with the Q-mode factor analysis without range transformation have shown that main factors are dominated by $N$. dutertrei, as expected, and that the systematic variations evident in less abundant species, such as $G$. ruber, $G$. sacculifer, and G. glutinata, are masked by the dominance of $N$. dutertrei. The use of range transformation resulted in better extraction of the systematic variations represented by these minor species, at the cost of some noise amplification. To minimize counting noise in the range-transformed data, we have excluded from the analysis the rare species that never reach $2 \%$ of the foraminiferal population in the downcore record of Site 846.

\section{Q-mode Factor Analysis of Site 846 Samples}

The 14 most abundant species were used in the factor analysis (Table 3). The first three factors explain $85 \%$ of the total variance of the 239 samples. If a fourth factor is used, it would only explain additional $2.9 \%$ of the total variance that are made up of $N$. pachyderma (right-coiling), G. ruber, and G. crassaformis. Therefore, the first three factors are deemed to have extracted systematic variation patterns in Site 846 assemblages. Table 3 also lists the varimax factor scores that define the three factors. Figure 8 displays the temporal variations of the factor loadings.

The first factor is a $N$. dutertrei-N. pachyderma factor and explains $40.5 \%$ of the total variance (Fig. 8). The time series variations of this factor principally reflect the abundance fluctuations of $N$. dutertrei and $N$. pachyderma, and do not show a consistent association with the $\delta^{18} \mathrm{O}$ record throughout the last 800 k.y. During the midBrunhes period, when dissolution was particularly severe, the abundances of these two species appear to have been related to dissolution; therefore, the factor loadings may be indicative of dissolution during that period.

The second factor is a $G$. ruber-G. menardii factor, explaining $24 \%$ of the total variance (Fig. 8). This factor also has relatively large scores on $G$. glutinata and $G$. sacculifer. As we argued earlier, $G$. ruber, G. sacculifer, and $G$. glutinata represent warm signals in Site 846 faunas; therefore, the time series fluctuations of this factor also represent warm signals. This factor shows higher loadings during interglacial periods than during glacial periods.

The third factor is a $G$. bulloides-N. pachyderma factor, and explains $23 \%$ of the total variance (Fig. 8). This factor has higher loadings during glacials and lower loadings during interglacials, a fluctuation pattern that is opposite to that of the second factor.

We caution that the variance explained by each factor in the above Q-mode factor analysis has lost its absolute sense, since range transformation was used to amplify the variabilities of minor species.

\section{Modern Distribution of Site 846 Factors}

To look for sources of the influences on the Site 846 faunas, we examined the planktonic foraminiferal species distribution in the 294 core-top samples distributed in the eastern Pacific Ocean (to the east of $180^{\circ}$ longitude) (Prell, 1985). Prell and Hays (1976) used matrix multiplication to project downcore factors onto core-top foraminiferal assemblages. In this study, however, the range transformation of the species abundances of the Site 846 samples necessitated a certain range transformation of modern core-top assemblages, but we were unable to find such a transformation that can not only be applied to both downcore and core-top samples, but also allows us to extract systematic downcore variations and to produce interpretable ecological assemblages in the core tops. As a result, we consider the distribution of those species that have large weightings in a factor as a firstorder approximation of the distribution of that factor, instead of using matrix multiplication. For each factor, a general boundary was drawn; 


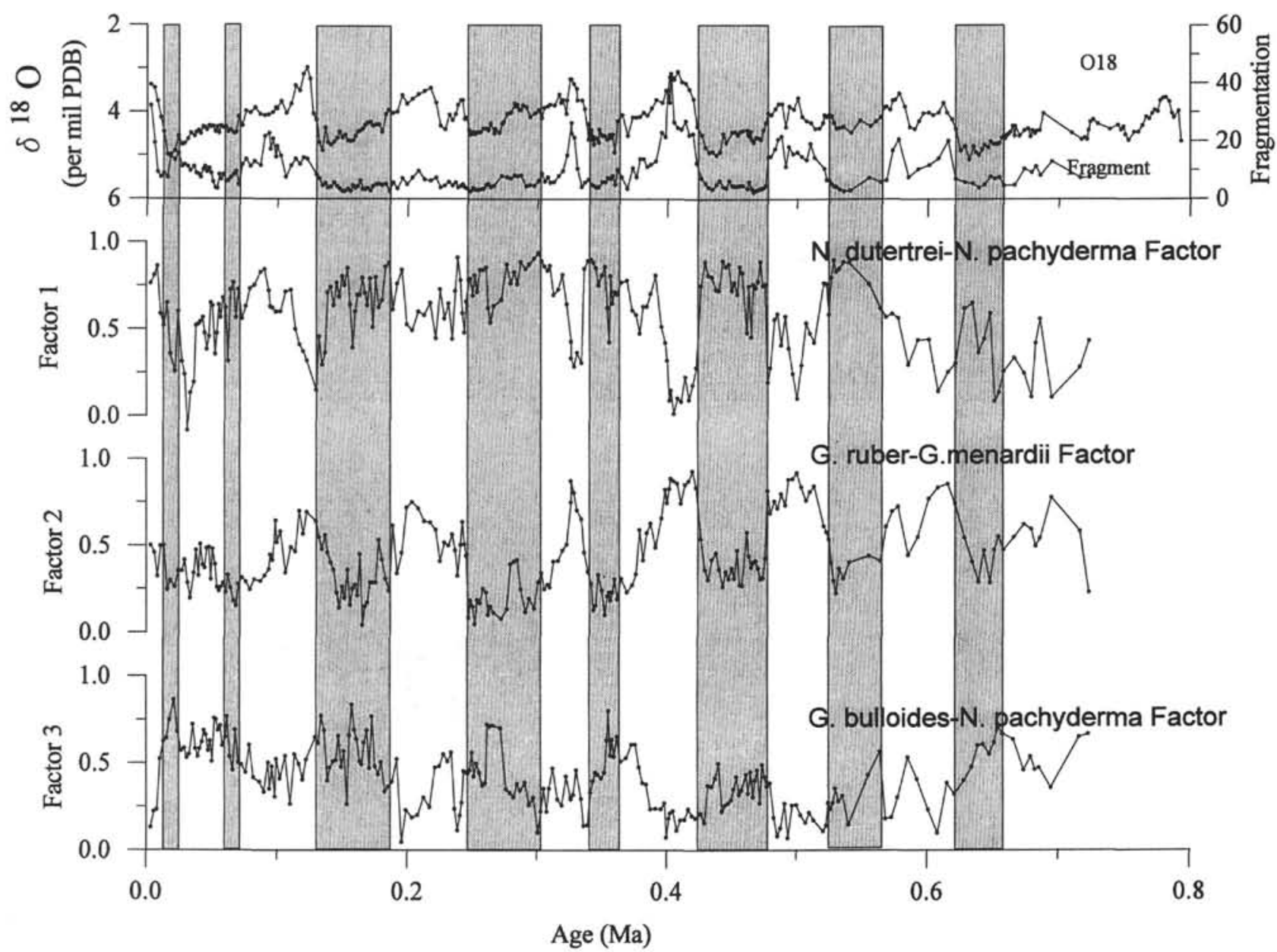

Figure 8. Temporal variations of the loadings of the three varimax factors resulted from Q-mode factor analysis of the Site 846 samples. The Site $846 \delta^{18} \mathrm{O}$ and fragmentation time series are plotted in the top panel for comparison. The shaded areas represent glacial stages.

this was done based on the presence of a high percentage of species, rather than detailed abundance variations.

The distribution of the first factor is approximated by the distribution of $N$. dutertrei plus dextral $N$. pachyderma. In the foraminiferal core-top assemblage data that is available to us, only three of 294 samples have dextral $N$. pachyderma. Therefore, the distribution of the first factor is virtually that of $N$. dutertrei. The reason for the absence of dextral $N$. pachyderma in the eastern Pacific foraminiferal data is probably because the dextral form was simply not recognized as a separate group. This factor is mainly distributed along the equator, approximately in the range between about $7^{\circ} \mathrm{N}$ and $6^{\circ} \mathrm{S}$ (Fig. 9A). The distribution approximately coincides with the area of "cool tongue" in the eastern tropical Pacific Ocean, where there is a shallow thermocline and rich nutrients in surface waters (Levitus et al., 1993). Factor 1 also dominates three core-top samples off Chile, perhaps a result of the offshore effects of upwelling in the Peru-Chile Current. Observations based on plankton tow and sediment trap data in the Panama Basin show that $N$. dutertre $i$ inhabits the thermocline; and when the thermocline shoals, the species flourishes (Thunell and Reynolds, 1984). This species is also abundant in offshore eastern boundary current waters of the Northern Hemisphere California Current (Bradshaw, 1959; Ortiz and Mix, 1992), as well as in upwelling waters off Peru (Thiede, 1983) and cool waters associated with the equatorial divergence.

The loadings of factor 1 are usually higher during glacial than during interglacial episodes. An exception is the last glacial maximum about 20 k.y. ago, when it was anomalously low. This could reflect the anomalously high abundance of $G$. inflata at that time, which acted
Table 3. Varimax factor scores resulting from Q-mode factor analysis of Site 846 foraminiferal data.

\begin{tabular}{lrrr}
\hline \multicolumn{1}{c}{ Species } & Factor I & Factor 2 & Factor 3 \\
\hline & & & \\
O. universa & 0.0215 & 0.1546 & 0.1488 \\
G. ruber & 0.0240 & 0.5094 & 0.0844 \\
G. sacculifer & -0.0133 & 0.3711 & -0.0706 \\
G. aequilateralis & -0.0227 & 0.1868 & 0.0447 \\
G. calida & 0.0411 & 0.2914 & 0.0782 \\
G. bulloides & 0.0375 & -0.1095 & 0.8219 \\
N. pachyderma (R) & 0.5349 & -0.1053 & 0.3098 \\
N. dutertrei & 0.8240 & 0.1401 & -0.1831 \\
P. obliquiloculata & -0.0419 & 0.2186 & 0.0816 \\
G. inflata & -0.1264 & 0.0070 & 0.2376 \\
G. crassaformis & -0.0130 & 0.0081 & 0.1144 \\
G. menardii & -0.0523 & 0.4485 & -0.1037 \\
G. tumida & -0.0067 & 0.0301 & 0.0601 \\
G. glutinata & -0.0969 & 0.4079 & 0.2493 \\
Variance (\%) & 40.5 & 23.6 & 21.2 \\
\cline { 2 - 4 } & & & \\
\end{tabular}

to decrease the relative abundance of all the other species. Therefore, based on the dominant distribution of $N$. dutertrei in the eastern equatorial "cool tongue," this factor may be indicative of shallow thermocline and rich nutrients. Note also that the abundance of $N$. dutertrei may have been affected by carbonate dissolution during the mid-Brunhes strong dissolution period.

The second $G$. ruber-G. menardii factor also includes significant influence from $G$. sacculifer and $G$. glutinata. Therefore, the distribution of this factor is approximated by the sum of the percentages of 

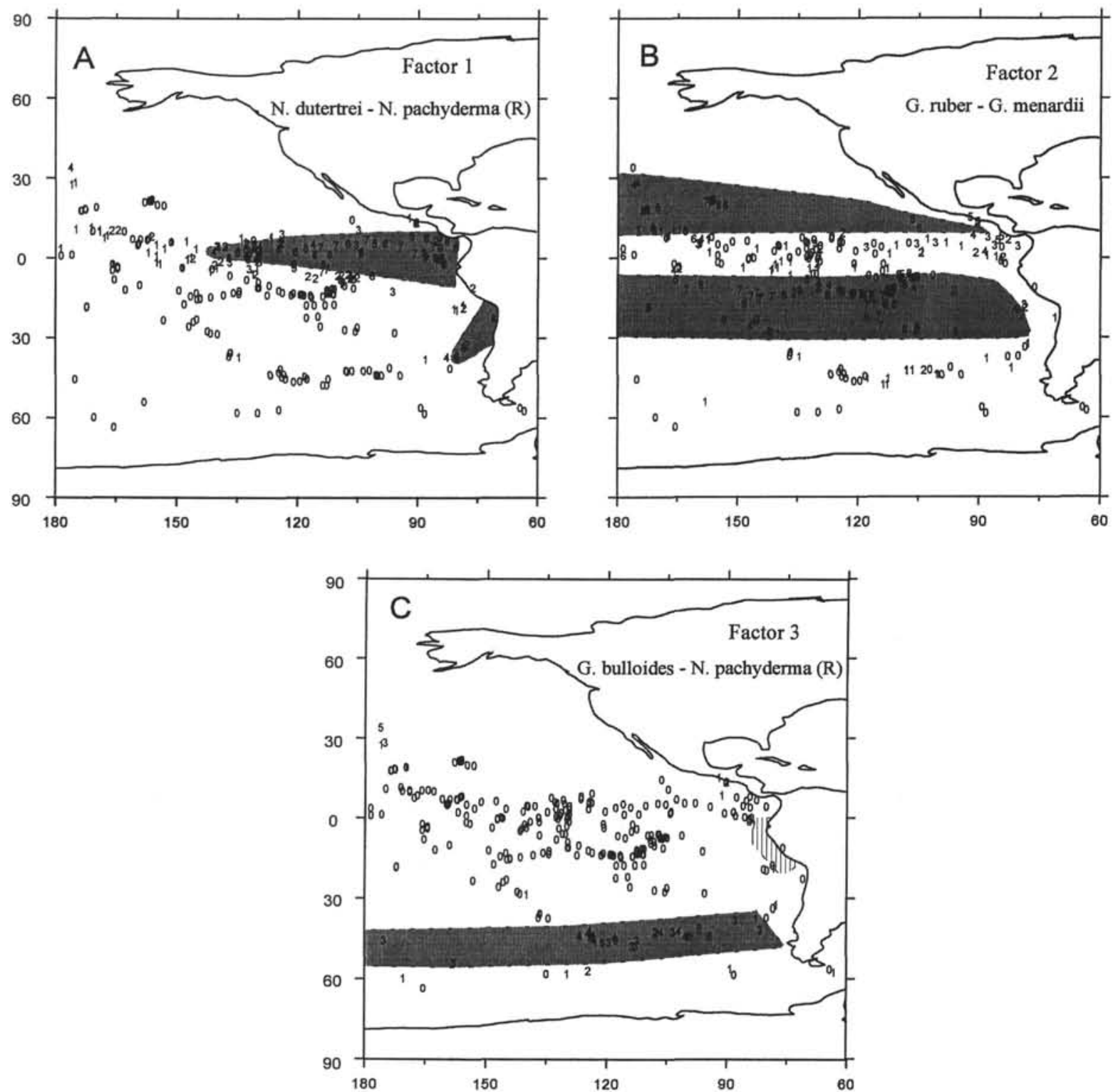

Figure 9. Geographical distributions of the three downcore factors derived from the Site 846 faunas. The distributions are approximated by the sum of the percentages of those species that have large factor scores in the core-top foraminiferal assemblages. A. Factor 1: N. dutertrei and dextrally coiling N. pachyderma. B. Factor 2: G. ruber, G. menardii, G. sacculifer, and G. glutinata. C. Factor 3: G. bulloides and dextrally coiling $N$. pachyderma. Note that the hatchured area off the Peru coast is based on plankton data of Thiede (1983). The above boundaries were drawn based on general presence of high percentages, rather than the detail.

these four species (Fig. 9B). As shown in the figure, this factor is mainly distributed in the subtropical waters off the equator and away from the eastern boundary because of the high abundances of $G$. ruber and $G$. glutinata. A number of samples in the Panama Basin also have moderate values on this factor as a result of abundant $G$. menardii. In general, the second factor is distributed in the area of warm tropical-subtropical surface water. The modern distribution of this factor confirms our earlier inference based on its temporal variation that this factor represents warm signals at Site 846.

The distribution of the third factor is represented by the sum of the percentages of G. bulloides and dextral N. pachyderma (Fig. 9C). The distribution of the factor primarily indicates the distribution of $G$. bulloides because of the absence of dextrally coiling $N$. pachyderma in the core-top samples. This factor is present in core tops underlying cool temperate areas south of $30^{\circ} \mathrm{S}$. This assemblage is also common in the northeast Pacific and the California Current (Bradshaw, 1959; Ortiz and Mix, 1992). The downcore record of factor 3 appears to be linked closely to abundance of $G$. bulloides, which is generally most abundant during glacial episodes. This species is considered to be mainly distributed in temperate-subpolar regions, it is also abundant in upwelling regions (Bé and Tolderlund, 1971; Thiede, 1983). Thiede (1983) showed that the concentrations of $G$. bulloides can reach $50 \%$ of the total living planktonic foraminifers off Peru in the region that is affected by upwelling. Therefore, high glacial loadings of factor 3 may result from offshore influence of strong coastal upwelling. However, it is also possible that $G$. bulloides was imported into the area during glacial time by a stronger and colder northwardflowing eastern boundary current.

Cross-spectral analyses were performed to study the variance distribution of these three factors in the frequency domain (Fig. 10). Table 1 tabulates the phase relationships of the factor loadings with the $-\delta^{18} \mathrm{O}$ time series and their coherencies at the 100,41 , and $23 \mathrm{k} . \mathrm{y}$. periods. Factor 1 shows a complicated power spectrum, containing variance at bands near 88,46 , and $22 \mathrm{k} . \mathrm{y}$.. This is probably because 

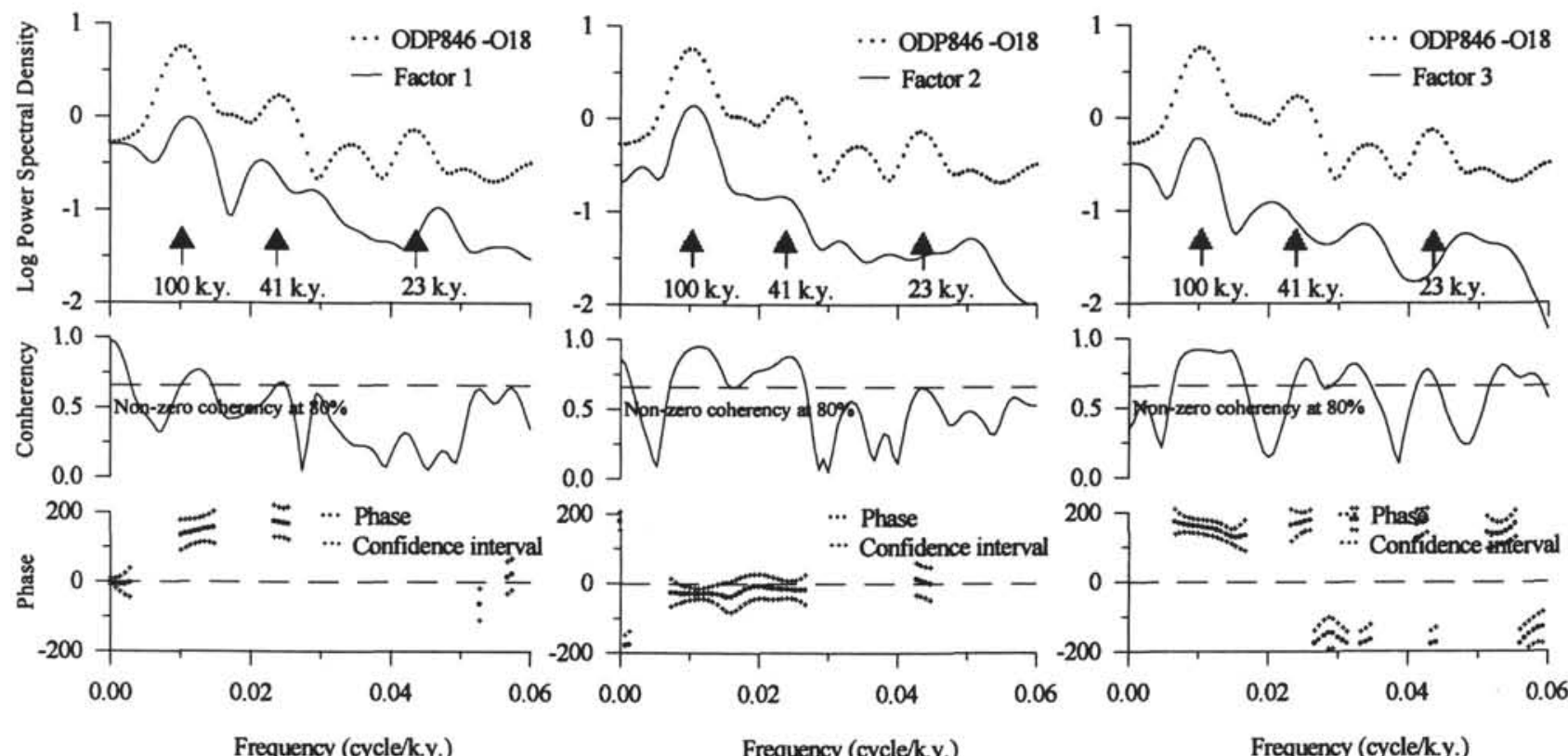

Frequency (cycle/k.y.)

Frequency (cycle/k.y.)

Frequency (cycle/k.y.)

Figure 10. Cross spectra between the Site $846-\delta^{18} \mathrm{O}$ and the time series of the three factors. The parameters for cross spectral analyses are the same as those in Figure 4. A positive phase angle indicates that ice volume minima lead factor loading maxima. For numerical value, see Table 1.

this factor has signatures of both thermocline depth and dissolution. During the mid-Brunhes strong dissolution period, this factor had about three 100 k.y. cycles; while at the period younger than $300 \mathrm{ka}$, the fluctuation patterns were more complicated. Both factors 2 and 3 have variance concentrated at the period of the 100 k.y. orbital eccentricity band. In this band, highest loadings of factor 2 lead ice volume minima by $30 \pm 19^{\circ}$ (coherency $=0.93$ ), and those of factor 3 lag ice volume maxima by $20 \pm 20^{\circ}$ (coherency $=0.92$ ). Factor 2 also has some concentration of variance at the orbital obliquity period of 41 k.y. (lead $-\delta^{18} \mathrm{O}$ by $18 \pm 25^{\circ}$ ). Factor 3 does not contain variance at either tilt or precession cycles, but instead has significant variance near periods at 50 and $30 \mathrm{k.y.}$

We interpret the significant lead of subtropical factor 2 as evidence for temperature changes in the South Equatorial Current leading ice volume, in agreement with evidence based on alkenone temperature estimates from the central equatorial Pacific (Lyle et al., 1992). Thus, the early warming relative to ice volume variations is not restricted to the equatorial divergence, but also is associated with large-scale structure of the SEC and eastern Pacific thermocline. In its phase, this signal at Site 846 is similar to that of the tropical Atlantic (McIntyre et al., 1989; Imbrie et al,. 1989). However, the Pacific SEC lacks the strong 23 k.y. signal of the tropical Atlantic Ocean, which is probably driven by the strength of the African monsoon (Mix et al., 1986; McIntyre et al, 1989; deMenocal et al., 1993).

\section{SUMMARY AND CONCLUSIONS}

Comparison of the data on planktonic foraminiferal faunas, fragmentation index, benthic foraminiferal abundances, and benthic $\delta^{18} \mathrm{O}$ over the last 800 k.y. in Site 846 yields the following results:

1. A fragmentation index records the effects of carbonate dissolution on the foraminiferal shells. The time series contains significant concentrations of variance at the $100 \mathrm{k} . \mathrm{y}$. eccentricity period and the 41 k.y. obliquity period. At these periods, maximum fragmentation occurs during interglacial extremes. Extreme fragmentation events occur during the mid-Brunhes (especially near $400 \mathrm{ka}$ ) and in Holocene sediments.

2. Higher fragmentation is often associated with high abundance of the dissolution-resistant species $G$. menardii, but also with the dis- solution-sensitive warm-water species $G$. ruber, $G$. glutinata, and $G$. sacculifer. Greater influx of fragile species during warm intervals may enhance fragmentation, but does not exclude the possibility that fragmentation may reflect changes in dissolution rate at the seafloor. The relatively high abundance of warm-water species during interglacials must indicate warmer and more subtropical upper-ocean conditions.

3. Benthic foraminiferal abundances resemble the fragmentation index, but do not record extreme events in the mid-Brunhes. The time series contains significant variance at the 100 k.y. cycle with a phase relationship similar to that of the fragmentation index. We suspect that they respond both to selective dissolution of planktonic foraminifers and to the flux of organic carbon flux to the seafloor, and thus cannot be interpreted simply.

4. Downcore variations in foraminiferal faunas can be expressed as three orthogonal Q-mode factors. These are interpreted by mapping the species that have large weightings on the factors on Pacific core-top foraminiferal assemblages. The first, containing $N$. dutertrei and right-coiling $N$. pachyderma, may reflect a shallow thermocline and nutrient rich waters in the eastern equatorial Pacific "cool tongue". The second, containing G. ruber, G. menardii, G. glutinata, and $G$. sacculifer, represents warm, subtropical waters. The third, dominated by $G$. bulloides, probably is associated with cold water upwelling along the eastern boundary. It is also possible that $G$. bulloides was transported from high latitudes by a colder and stronger eastern boundary current during glacial times.

5 . Factor 1 does not vary consistently relative to glacial-interglacial cycles. This suggests multiple, sometimes competing causes for variation of this factor, including upper ocean structure, productivity, and dissolution. Both factors 2 and 3 vary, mostly antithetically, with a strong 100 k.y. rhythm. Warm conditions lead interglacial maxima, and cold conditions are perhaps linked to advection of cold upwelled water off the Peru margin during glacial maxima, and possibly a stronger eastern boundary current. Subtropical factor 2 also contains significant variance, coherent with $\delta^{18} \mathrm{O}$, at the $41 \mathrm{k} . \mathrm{y}$. band (warmest episodes leading interglacial events by $18 \pm 25^{\circ}$ ).

We conclude that the foraminiferal faunal signals at Site 846 , although influenced by dissolution, are interpretable in terms of the changing characteristics of upper ocean waters. Prior to and during interglacial periods, the area was considerably warmer and more sub- 
tropical than at present; during glacial periods, the area was colder than at present with greater upwelling and advection off the eastern boundary, and possibly a stronger and colder Peru Current. The "cold tongue" associated with the South Equatorial Current may also have been stronger during glacial maxima.

\section{ACKNOWLEDGMENTS}

We are grateful to M. Hall and B. Rugh for running mass spectrometers; D. Pate, J. Wilson, and A. Morey for sample processing. We thank S. Crowhurst and E. Tappa for reading the manuscript, and R.C. Thunell for helpful discussions. This work is supported by the NERC of Great Britain, and the NSF and USSAC in the United States. Thanks are also extended to the post-doctoral support of the University of South Carolina.

\section{REFERENCES}

Adelseck, C.G., Jr., and Anderson, T.F., 1978. The late Pleistocene record of productivity fluctuations in the eastern equatorial Pacific Ocean. Geology, 6:388-391.

Bé, A.W.H., and Tolderlund, D.S., 1971. Distribution and ecology of living planktonic foraminifera in surface waters of the Atlantic and Indian Oceans. In Funnel, B.M., and Riedel, W.R. (Eds.), The Micropaleontology of Oceans: Cambridge (Cambridge Univ. Press), 105-149.

Berger, W.H., 1973. Deep-sea carbonates: Pleistocene dissolution cycles. J. Foraminiferal Res., 3:187-195.

Berger, W.H., Bonneau, M.-C., and Parker, F.L., 1982. Foraminifera on the deep-sea floor: lysocline and dissolution rate. Oceanol. Acta, 5:249-258.

Berger, W.H., and Diester-Haass, L., 1988. Paleoproductivity: the benthic planktonic ratio in foraminifera as a productivity index. Mar. Geol., $81: 15-25$.

Bradshaw, J.S., 1959. Ecology of living planktonic foraminifera in the North and Equatorial Pacific Ocean. Contrib. Cushman Found. Foraminiferal Res., 10:25-64.

Bryden, H.L., and Brady, E.C., 1985. Diagnostic model of the three-dimensional circulation in the upper Equatorial Pacific Ocean. J. Phys. Oceanogr., 15:1255-1273.

CLIMAP Project Members, 1976. The surface of the ice-age Earth. Science, 191:1131-1137.

1981. Seasonal reconstructions of the Earth's surface at the last glacial maximum. Geol. Soc. Am., Map and Chart Ser., MC36:1-18.

deMenocal, P.B., Ruddiman, W.F., and Pokras, E.M., 1993. Influence of highand low-latitude on African terrestrial climate: Pleistocene eolian records from equatorial Atlantic Ocean Drilling Program Site 663. Paleoceanography, 8:209-242.

Farrell, J.W., and Prell, W.L., 1989. Climatic change and $\mathrm{CaCO}_{3}$ preservation: an 800,000 year bathymetric reconstruction from the central equatorial Pacific Ocean. Paleoceanography, 4:447-466.

Francois, R., Macon, M.P., and Suman, D.O., 1990. Thorium 230 profiling in deep-sea sediments: high-resolution records of flux and dissolution of carbonate in the equatorial Atlantic during the last 24,000 years. Paleoceanography, 5:761-787.

Hagelberg, T., Shackleton, N., Pisias, N., and Shipboard Scientific Party, 1992. Development of composite depth sections for Sites 844 through 854 . In Mayer, L., Pisias, N., Janecek, T., et al., Proc. ODP, Init. Repts., 138 (Pt. 1): College Station, TX (Ocean Drilling Program), 79-85.

Halpern, D., Ashby, H., Finch, C., and Robels, J., 1990. TOGA CD-ROM description. JPL Publ., 90-43.

Hays, P.E., Pisias, N.G., and Roelofs, A.K., 1989. Paleoceanography of the eastern equatorial Pacific during the Pliocene: a high-resolution radiolarian study. Paleoceanography, 4:57-73.

Herguera, J.C., and Berger, W.H., 1991. Paleoproductivity: glacial to postglacial change in the western equatorial Pacific, from benthic foraminifera. Geology, 19:1173-1176.

\footnotetext{
Abbreviations for names of organizations and publication titles in ODP reference lists follow the style given in Chemical Abstracts Service Source Index (published by American Chemical Society).
}

Imbrie, J., Hays, J.D., Martinson, D.G., McIntyre, A., Mix, A.C., Morley, J.J., Pisias, N.G., Prell, W.L., and Shackleton, N.J., 1984. The orbital theory of Pleistocene climate: support from a revised chronology of the marine $\delta^{18} \mathrm{O}$ record. In Berger, A., Imbrie, J., Hays, J., Kukla, G., and Saltzman, B. (Eds.), Milankovitch and Climate (Pt. 1): Dordrecht (D. Reidel), 269-305.

Imbrie, J., and Kipp, N.G., 1971. A new micropaleontological method for quantitative paleoclimatology: application to a late Pleistocene Caribbean core. In Turekian, K.K. (Ed.), The Late Cenozoic Glacial Ages: New Haven (Yale Univ. Press), 71-181.

Jenkins, G.M., and Watts, D.G., 1968. Spectral Analysis and Its Applications: San Francisco (Holden Day).

Keir, R.S., and Berger, W.H., 1985. Late Holocene carbonate dissolution in the Equatorial Pacific: reef growth or neoglaciation? The Carbon Cycle and Atmospheric $\mathrm{CO}_{2}$ : Natural Variations Archean to Present. Am. Geophys. Union, Geophys. Monogr., 32:208-219.

Kennett, J.P., 1976. Phenotypic variation in some Recent and late Cenozoic planktonic foraminifera. In Adams, C.G., and Hedley, R.H. (Eds.), Foraminifera, 2:111-170.

Kipp, N.G., 1976. New transfer function for estimating past sea-surface conditions from sea-bed distribution of planktonic foraminiferal assemblages in the north Atlantic. In Cline, R.M., and Hays, J.D. (Eds.), Investigation of Late Quaternary Paleoceanography and Paleoclimatology. Mem.-Geol. Soc. Am., 145:3-41.

Le, J., 1991. Temperature and carbonate dissolution variability in the western equatorial pacific during the late Quaternary [Ph.D. thesis], Univ. of Cambridge, Cambridge, England.

Le, J., and Shackleton, N.J., 1992. Carbonate dissolution fluctuations in the western equatorial Pacific during the late Quaternary. Paleoceanography, $7: 21-42$.

Levitus, S., Conkright, M.E., Reid, J.L., Najjar, R.G., and Mantyla, N.A., 1993. Distribution of nitrate phosphate, and silicate in the world oceans. Prog. Oceanogr., 31:245-273.

Lyle, M.W.,Prahl, F.G., and Sparrow, M.A., 1992. Upwelling and productivity changes inferred from temperature record in the central equatorial Pacific. Nature, 355:812-815.

Martinson, D.G., Menke, W., and Stoffa, P.L., 1982. An inverse approach to signal correlation. J. Geophys. Res., 87:4807-4818.

Mayer, L., Pisias, N., Janecek, T., et al., 1992. Proc. ODP, Init. Repts., 138 (Pts. 1 and 2): College Station, TX (Ocean Drilling Program).

McIntyre, A., Ruddiman, W.F., Karlin, K., and Mix, A.C., 1989. Surface water response of the equatorial Atlantic Ocean to orbital forcing. Paleoceanography, 4:19-55.

Mix, A.C., Ruddiman, W.F., and McIntyre, A., 1986. The late Quaternary paleoceanography of the tropical Atlantic. 1: Spatial variability of annual mean sea-surface temperatures, 0-20,000 years B.P. Paleoceanography, 1:43-66.

Ortiz, J.D., and Mix, A.C., 1992. The spacial distribution and seasonal succession of planktonic foraminifera in the California Current off Oregon, September 1987-September 1988. In Summerhayes, C.P., Prell, W.L., and Emeis, K.C. (Eds.), Upwelling Systems: Evolution Since the Early Miocene. Geol. Soc. Spec. Publ. London, 64:197-213.

Parker, F.L., and Berger, W.H., 1971. Faunal and solution patterns of planktonic Foraminifera in surface sediments of the South Pacific. Deep-Sea Res. Part A, 18:73-107.

Philander, S.G.H., 1990. El Niño, La Niña and the Southern Oscillation: New York (Academic Press).

Prell, W.L., 1985. The stability of low-latitude sea-surface temperatures: an evaluation of the CLIMAP reconstruction with emphasis on the positive SST anomalies. Dept. Energy Tech. Rept., TR-025.

Prell, W.L., and Curry, W.B., 1981. Faunal and isotopic indices of monsoonal upwelling: western Arabian Sea. Oceanol. Acta, 4:91-98.

Prell, W.L., and Hays, J.D., 1976. Late Pleistocene faunal and temperature patterns of the Colombia Basin, Caribbean Sea. In Cline, R.M., and Hays, J.D. (Eds.), Investigation of Late Quaternary Paleoceanography and Paleoclimatology. Mem. -Geol. Soc. Am., 145:201-220.

Romine, K., 1982. Late Quaternary history of atmospheric and oceanic circulation in the eastern equatorial Pacific. Mar. Micropaleontol., 7:163-187.

Schramm, C.T., 1985. Implications of radiolarian assemblages for the Late Quaternary paleoceanography of the eastern equatorial Pacific. Quat. Res., $24: 204-218$.

Shackleton, N.J., 1974. Attainment of isotopic equilibrium between ocean water and the benthonic foraminifera genus Uvigerina: isotopic changes in the ocean during the last glacial. Les Meth. Quant. d'etude Var. Clim. au Cours du Pleist., Coll. Int. C.N.R.S., 219:203-209. 
Shackleton, N.J., Berger, A., and Peltier, W.R., 1990. An alternative astronomical calibration of the lower Pleistocene timescale based on ODP Site 677. Trans. R. Soc. Edinburgh, Earth Sci., 81:251-261.

Shipboard Scientific Party, 1992. Site 846. In Mayer, L., Pisias, N., Janecek, T., et al., 1992. Proc. ODP, Init. Repts., 138: College Station, TX (Ocean Drilling Program), 265-333.

Thiede, J., 1983. Skeletal plankton and nekton in upwelling water masses off northwestern South America and Northwest Africa. In Suess, E., and Thiede, J. (Eds.), Coastal Upwelling: Its Sediment Record (Pt. A): Response of the Sedimentary Regime to Present Coastal Upwelling: New York (Plenum), 183-207.

Thunell, R.C., 1976. Optimum indices of calcium carbonate dissolution in deep-sea sediments. Geology, 4:525-528.

Thunell, R.C., and Reynolds, L.A., 1984. Sedimentation of planktonic foraminifera: seasonal changes in species flux in the Panama Basin. Micropaleontology, 30:243-262.
Toggweiler, J.R., Dixon, K., and Broecker, W.S., 1991. The Peru upwelling and the ventilation of the south Pacific thermocline. J. Geophys. Res., 96:20467-20497.

Valencia, M., 1977. Pleistocene stratigraphy of the western equatorial Pacific. Geol. Soc. Am. Bull., 85:1789-1802.

Wyrtki, K., 1966. Oceanography of the eastern equatorial Pacific Ocean. Oceanogr. Mar. Biol. Ann. Rev., 4:33-68.

, 1981. An estimate of equatorial upwelling in the Pacific. J. Phys. Oceanogr., 11:1205-1214.

Date of initial receipt: 3 March 1993

Date of acceptance: 21 March 1994

Ms 138SR-138 
APPENDIX

Relative Abundance of Site 846 Foraminifers

\begin{tabular}{|c|c|c|c|c|c|c|c|c|c|c|c|c|}
\hline \multirow{2}{*}{$\begin{array}{l}\text { Core, section, } \\
\text { interval }(\mathrm{cm})\end{array}$} & Shipboard & & & & & & & ecies & & & & \\
\hline & & med) & O. uni. & G. rub. & G. ten. & G. sac. & G. aeq. & G. cal. & G. bul. & G. rbs. & N.pa. R & N. dut. \\
\hline $846 \mathrm{~B}-1 \mathrm{H}-1,12$ & 0.12 & 0.12 & 0.3 & 1.1 & 0.0 & 1.8 & 0.5 & 0.5 & 4.4 & 0.0 & 13.4 & 66.1 \\
\hline $846 \mathrm{~B}-1 \mathrm{H}-1,24$ & 0.24 & 0.24 & 1.1 & 2,9 & 0.0 & 0.9 & 0.0 & 0.0 & 6.3 & 0.3 & 17.7 & 62.6 \\
\hline $846 \mathrm{~B}-1 \mathrm{H}-1,33$ & 0.33 & 0.33 & 0.0 & 1.7 & 0.3 & 0.3 & 0.8 & 0.3 & 9.5 & 0.6 & 15.4 & 64.7 \\
\hline $846 \mathrm{~B}-1 \mathrm{H}-1.43$ & 0.43 & 0.43 & 1.0 & 1.7 & 0.5 & 1.4 & 1.2 & 1.0 & 13.7 & 0.0 & 19.2 & 50.5 \\
\hline 846B-IH-I, 53 & 0.53 & 0.53 & 0.7 & 3.3 & 0.3 & 2.3 & 0.3 & 0.3 & 17.7 & 0.0 & 17.7 & 45.8 \\
\hline $846 \mathrm{~B}-1 \mathrm{H}-1.63$ & 0.63 & 0.63 & 1.7 & 0.5 & 0.0 & 1.4 & 0.2 & 1.2 & 14.9 & 0.0 & 27.3 & 44.3 \\
\hline $846 \mathrm{~B}-1 \mathrm{H}-1,73$ & 0.73 & 0.73 & 0.8 & 0.6 & 0.0 & 1.4 & 0.0 & 0.6 & 16.2 & 0.0 & 15.9 & 39.8 \\
\hline $846 \mathrm{~B}-1 \mathrm{H}-1,88$ & 0.88 & 0.88 & 0.2 & 0.9 & 0.0 & 0.5 & 0.5 & 0.5 & 21.4 & 0.0 & 15.3 & 37.2 \\
\hline $846 \mathrm{~B}-1 \mathrm{H}-1,100$ & 1.00 & 1.00 & 1.2 & 1.8 & 0.0 & 0.6 & 0.3 & 0.9 & 15.0 & 0.0 & 19.3 & 45.7 \\
\hline $846 \mathrm{~B}-1 \mathrm{H}-1,113$ & 1.13 & 1.13 & 4.3 & 2.0 & 0.0 & 0.2 & 0.4 & 0.0 & 9.4 & 0.0 & 12.4 & 41.1 \\
\hline $846 \mathrm{~B}-1 \mathrm{H}-1,124$ & 1.23 & 1.23 & 5.6 & 1.2 & 0.0 & 0.3 & 0.0 & 0.3 & 10.9 & 0.0 & 7.0 & 43.9 \\
\hline $846 \mathrm{~B}-1 \mathrm{H}-1,133$ & 1.33 & 1.33 & 4.1 & 0.5 & 0.0 & 0.5 & 0.5 & 0.5 & 8.7 & 0.0 & 5.0 & 31.5 \\
\hline $846 \mathrm{~B}-1 \mathrm{H}-1,145$ & 1.44 & 1.44 & 0.9 & 0.2 & 0.0 & 0.2 & 0.0 & 0.7 & 11.5 & 0.0 & 4.9 & 40.3 \\
\hline $846 \mathrm{~B}-1 \mathrm{H}-2,9$ & 1.59 & 1.59 & 3.8 & 1.6 & 0.0 & 0.0 & 0.3 & 1.3 & 16.2 & 0.0 & 6.4 & 39.9 \\
\hline 846B-IH-2, 19 & 1.68 & 1.68 & 5.7 & 2.4 & 0.0 & 1.1 & 0.7 & 1.1 & 16.0 & 0.0 & 10.4 & 50.3 \\
\hline $846 \mathrm{~B}-1 \mathrm{H}-2,29$ & 1.79 & 1.79 & 0.7 & 1.7 & 0.0 & 0.7 & 0.3 & 1.4 & 19.4 & 0.0 & 10.3 & 54.6 \\
\hline $846 \mathrm{~B}-1 \mathrm{H}-2,37$ & 1.87 & 1.87 & 3.5 & 3.5 & 0.0 & 0.4 & 0.2 & 0.6 & 18.1 & 0.0 & 11.6 & 53.1 \\
\hline $846 \mathrm{~B}-\mathrm{IH}-2,48$ & 1.98 & 1.98 & 4.8 & 1.1 & 0.0 & 0.8 & 0.3 & 0.3 & 18.6 & 0.0 & 13.4 & 51.9 \\
\hline $846 \mathrm{~B}-1 \mathrm{H}-2.57$ & 2.07 & 2.07 & 1.8 & 0.7 & 0.0 & 0.2 & 0.7 & 1.1 & 21.6 & 0.0 & 14.0 & 49.3 \\
\hline $846 \mathrm{~B}-1 \mathrm{H}-2,68$ & 2.17 & 2.17 & 3.6 & 2.2 & 0.0 & 0.4 & 0.4 & 0.9 & 20.2 & 0.0 & 13.6 & 47.9 \\
\hline $846 \mathrm{~B}-1 \mathrm{H}-2,78$ & 2.28 & 2.28 & 1.3 & 3.5 & 0.0 & 0.0 & 0.2 & 0.4 & 16.5 & 0.0 & 15.9 & 50.5 \\
\hline $846 \mathrm{~B}-1 \mathrm{H}-2,88$ & 2.38 & 2.38 & 0.5 & 1.0 & 0.0 & 0.0 & 0.3 & 1.6 & 17.7 & 0.0 & 21.0 & 51.2 \\
\hline $846 \mathrm{~B}-1 \mathrm{H}-2,97$ & 2.47 & 2.47 & 1.6 & 2,3 & 0.0 & 0.5 & 0.7 & 0.7 & 13.8 & 0.0 & 16.7 & 54.5 \\
\hline $846 \mathrm{~B}-\mathrm{IH}-2,109$ & 2.59 & 2.59 & 2.2 & 1.9 & 0.0 & 0.6 & 0.9 & 2.5 & 27.3 & 0.0 & 12.9 & 43.9 \\
\hline $846 \mathrm{~B}-1 \mathrm{H}-2,117$ & 2.67 & 2.67 & 0.7 & 2.4 & 0.0 & 0.5 & 0.0 & 1.4 & 28.9 & 0.0 & 13.1 & 48.9 \\
\hline $846 \mathrm{~B}-1 \mathrm{H}-2,128$ & 2.78 & 2.78 & 2.2 & 1.3 & 0.0 & 0.0 & 0.0 & 1.3 & 20.9 & 0.0 & 15.8 & 50.9 \\
\hline $846 \mathrm{~B}-\mathrm{IH}-2,137$ & 2.87 & 2.87 & 0.7 & 1.6 & 0.0 & 0.0 & 0.0 & 0.5 & 22.5 & 0.2 & 16.0 & 48.8 \\
\hline $846 \mathrm{~B}-1 \mathrm{H}-2,146$ & 2.96 & 2.96 & 0.5 & 0.7 & 0.0 & 0.0 & 0.0 & 0.7 & 17.0 & 0.0 & 17.9 & 53.8 \\
\hline $846 \mathrm{~B}-1 \mathrm{H}-3,9$ & 3.09 & 3.09 & 0.6 & 0.8 & 0.0 & 0.0 & 0.0 & 1.2 & 13.5 & 0.0 & 17.9 & 48.0 \\
\hline $846 \mathrm{~B}-1 \mathrm{H}-3,18$ & 3.18 & 3.18 & 1.5 & 2.3 & 0.0 & 0.0 & 0.0 & 1.1 & 15.3 & 0.0 & 15.1 & 38.0 \\
\hline $846 \mathrm{~B}-1 \mathrm{H}-3,28$ & 3.28 & 3.28 & 0.4 & 0.8 & 0.0 & 0.0 & 0.0 & 0.8 & 14.3 & 0.0 & 14.3 & 55.2 \\
\hline $846 \mathrm{~B}-1 \mathrm{H}-3,39$ & 3.39 & 3.39 & 2.0 & 0.4 & 0.0 & 0.0 & 0.0 & 0.4 & 16.6 & 0.0 & 14.8 & 61.1 \\
\hline $846 \mathrm{~B}-1 \mathrm{H}-3,48$ & 3.48 & 3.48 & 0.8 & 0.8 & 0.0 & 0.0 & 0.6 & 0.2 & 24.4 & 0.2 & 16.4 & 50.1 \\
\hline $846 \mathrm{~B}-1 \mathrm{H}-3,57$ & 3.57 & 3.57 & 1.8 & 1.8 & 0.0 & 0.0 & 0.0 & 0.4 & 16.1 & 0.0 & 15.8 & 57.4 \\
\hline $846 \mathrm{~B}-1 \mathrm{H}-3,67$ & 3.67 & 3.67 & 2.3 & 0.8 & 0.0 & 0.0 & 0.8 & 1.1 & 16.3 & 0.0 & 15.0 & 54.6 \\
\hline $846 \mathrm{~B}-1 \mathrm{H}-3,78$ & 3.78 & 3.78 & 3.7 & 0.0 & 0.0 & 0.3 & 0.0 & 1.0 & 12.2 & 0.0 & 19.4 & 54.8 \\
\hline $846 \mathrm{~B}-1 \mathrm{H}-3,88$ & 3.88 & 3.88 & 1.2 & 1.9 & 0.0 & 0.0 & 0.0 & 0.3 & 16.8 & 0.3 & 21.4 & 50.9 \\
\hline $846 \mathrm{~B}-1 \mathrm{H}-3,98$ & 3.98 & 3.98 & 0.0 & 1.0 & 0.0 & 0.0 & 0.5 & 2.6 & 13.3 & 1.5 & 18.7 & 54.1 \\
\hline $846 \mathrm{~B}-1 \mathrm{H}-3,108$ & 4.09 & 4.11 & 0.8 & 1.2 & 0.0 & 0.0 & 0.0 & 1.2 & 13.8 & 0.0 & 15.4 & 62.8 \\
\hline $846 \mathrm{~B}-\mathrm{IH}-3,118$ & 4.18 & 4.20 & 0.6 & 0.8 & 0.0 & 0.0 & 0.6 & 1.1 & 10.1 & 0.0 & 18.2 & 61.5 \\
\hline $846 \mathrm{D}-1 \mathrm{H}-1,128$ & 4.28 & 4.29 & 1.9 & 1.9 & 0.0 & 1.4 & 1.4 & 0.0 & 15.4 & 0.0 & 7.7 & 60.0 \\
\hline $846 \mathrm{~B}-1 \mathrm{H}-3,118$ & 4.18 & 4.32 & 0.2 & 1.4 & 0.0 & 0.0 & 0.0 & 0.5 & 14.9 & 0.0 & 16.2 & 55.7 \\
\hline $846 \mathrm{D}-1 \mathrm{H}-1,137$ & 4.37 & 4.37 & 1.3 & 4.1 & 0.0 & 0.5 & 1.0 & 1.6 & 5.7 & 0.0 & 19.9 & 53.5 \\
\hline $846 \mathrm{~B}-1 \mathrm{H}-3,128$ & 4.28 & 4.43 & 0.0 & 0.8 & 0.0 & 0.5 & 0.8 & 1.6 & 14.2 & 0.0 & 18.7 & 51.0 \\
\hline $846 \mathrm{D}-1 \mathrm{H}-1,146$ & 4.46 & 4.46 & 1.0 & 2.9 & 0.0 & 2.2 & 1.0 & 0.5 & 13.7 & 0.0 & 11.8 & 57.2 \\
\hline $846 \mathrm{~B}-1 \mathrm{H}-3,138$ & 4.38 & 4.54 & 1.2 & 2.8 & 0.0 & 0.7 & 0.7 & 0.5 & 13.6 & 0.2 & 18.7 & 48.9 \\
\hline $846 \mathrm{D}-1 \mathrm{H}-1,148$ & 4.48 & 4.66 & 1.2 & 2.0 & 0.2 & 0.2 & 1.0 & 1.0 & 14.1 & 0.0 & 24.6 & 51.6 \\
\hline 846D-1H-2, 8 & 4.58 & 4.78 & 1.0 & 2.8 & 0.0 & 1.7 & 1.4 & 0.0 & 9.4 & 0.0 & 14.8 & 62.6 \\
\hline $846 \mathrm{D}-1 \mathrm{H}-2,18$ & 4.68 & 4.90 & 1.1 & 2.8 & 0.0 & 0.6 & 1.1 & 1.1 & 14.9 & 0.0 & 21.7 & 46.3 \\
\hline $846 \mathrm{D}-1 \mathrm{H}-2,28$ & 4.78 & 5.01 & 0.8 & 3.2 & 0.0 & 1.2 & 0.8 & 2.4 & 11.6 & 0.0 & 18.8 & 44.7 \\
\hline $846 \mathrm{D}-1 \mathrm{H}-2,38$ & 4.88 & 5.12 & 0.5 & 4.1 & 0.0 & 2.3 & 0.0 & 0.5 & 10.5 & 0.5 & 20.3 & 46.5 \\
\hline $846 \mathrm{D}-1 \mathrm{H}-2,48$ & 4.98 & 5.22 & 3.1 & 4.7 & 0.3 & 2.2 & 0.3 & 2.5 & 13.1 & 0.0 & 18.0 & 42.7 \\
\hline $846 \mathrm{D}-1 \mathrm{H}-2,78$ & 5.28 & 5.52 & 0.9 & 5.5 & 0.2 & 3.0 & 0.7 & 1.6 & 27.2 & 0.2 & 9.4 & 39.5 \\
\hline $846 \mathrm{D}-1 \mathrm{H}-2,88$ & 5.38 & 5.62 & 0.5 & 3.1 & 0.2 & 1.7 & 0.7 & 1.9 & 23.2 & 0.0 & 10.7 & 53.1 \\
\hline $846 \mathrm{D}-1 \mathrm{H}-2,98$ & 5.48 & 5.72 & 0.3 & 3.0 & 0.0 & 0.8 & 0.3 & 1.6 & 25.4 & 0.0 & 14.5 & 40.4 \\
\hline $846 \mathrm{D}-1 \mathrm{H}-2,108$ & 5.58 & 5.82 & 2.3 & 3.2 & 0.0 & 0.6 & 1.0 & 1.9 & 21.4 & 0.0 & 12.3 & 44.2 \\
\hline $846 \mathrm{D}-1 \mathrm{H}-2,118$ & 5.68 & 5.92 & 2.0 & 2.5 & 0.0 & 1.8 & 0.0 & 0.9 & 14.6 & 0.0 & 11.7 & 59.2 \\
\hline $846 \mathrm{D}-\mathrm{IH}-2,128$ & 5.78 & 6.02 & 0.4 & 2.2 & 0.4 & 0.4 & 0.0 & 0.8 & 11.8 & 0.0 & 20.5 & 54.5 \\
\hline $846 \mathrm{D}-1 \mathrm{H}-2,138$ & 5.88 & 6.13 & 0.6 & 2.9 & 0.0 & 0.4 & 0.2 & 0.4 & 13.9 & 0.0 & 18.9 & 52.7 \\
\hline $846 \mathrm{D}-1 \mathrm{H}-2,148$ & 5.98 & 6.23 & 0.8 & 0.8 & 0.0 & 0.6 & 0.2 & 0.8 & 16.8 & 0.0 & 19.5 & 61.2 \\
\hline $846 \mathrm{D}-\mathrm{IH}-3,8$ & 6.08 & 6.33 & 1.4 & 0.7 & 0.0 & 0.9 & 0.0 & 0.4 & 18.4 & 0.0 & 25.7 & 48.1 \\
\hline $846 \mathrm{D}-1 \mathrm{H}-3,18$ & 6.18 & 6.43 & 1.1 & 1.4 & 0.0 & 0.0 & 0.0 & 1.1 & 10.6 & 0.0 & 26.7 & 53.5 \\
\hline $846 \mathrm{D}-1 \mathrm{H}-3,28$ & 6.28 & 6.53 & 0.8 & 1.0 & 0.0 & 0.4 & 0.0 & 1.2 & 15.9 & 0.0 & 25.8 & 51.6 \\
\hline $846 \mathrm{D}-1 \mathrm{H}-3,38$ & 6.38 & 6.63 & 1.2 & 1.6 & 0.0 & 1.6 & 0.0 & 0.0 & 8.8 & 0.0 & 17.5 & 64.1 \\
\hline $846 \mathrm{D}-\mathrm{IH}-3,48$ & 6.48 & 6.72 & 1.3 & 1.3 & 0.0 & 0.2 & 0.0 & 0.2 & 24.3 & 0.0 & 15.5 & 54.1 \\
\hline $846 \mathrm{D}-1 \mathrm{H}-3,58$ & 6.58 & 6.82 & 1.5 & 2.1 & 0.0 & 0.5 & 0.0 & 1.0 & 29.3 & 0.0 & 18.7 & 42.0 \\
\hline $846 \mathrm{D}-1 \mathrm{H}-3,68$ & 6.68 & 6.91 & 1.1 & 1.9 & 0.0 & 0.0 & 0.2 & 1.1 & 23.2 & 0.2 & 15.1 & 51.5 \\
\hline $846 \mathrm{D}-1 \mathrm{H}-3,78$ & 6.78 & 7.00 & 0.8 & 1.1 & 0.0 & 0.0 & 0.0 & 0.8 & 20.2 & 0.4 & 17.9 & 52.9 \\
\hline $846 \mathrm{D}-1 \mathrm{H}-3,88$ & 6.88 & 7.10 & 0.8 & 3.0 & 0.2 & 1.0 & 0.0 & 1.0 & 12.6 & 0.2 & 23.4 & 50.5 \\
\hline $846 \mathrm{D}-1 \mathrm{H}-3,98$ & 6.98 & 7.18 & 0.0 & 0.6 & 0.0 & 0.3 & 0.0 & 0.6 & 12.5 & 0.0 & 35.2 & 49.3 \\
\hline $846 \mathrm{D}-1 \mathrm{H}-3,108$ & 7.08 & 7.27 & 1.7 & 1.4 & 0.3 & 0.3 & 0.3 & 0.0 & 18.6 & 0.0 & 24.6 & 50.3 \\
\hline $846 \mathrm{D}-1 \mathrm{H}-3,118$ & 7.18 & 7.36 & 1.2 & 1.5 & 0.3 & 0.6 & 0.3 & 0.6 & 23.5 & 0.0 & 18.4 & 50.1 \\
\hline $846 \mathrm{D}-1 \mathrm{H}-3,128$ & 7.28 & 7.45 & 4.2 & 1.0 & 0.0 & 1.0 & 0.0 & 0.3 & 14.2 & 0.0 & 17.6 & 57.9 \\
\hline $846 \mathrm{D}-1 \mathrm{H}-3,138$ & 7.38 & 7.54 & 3.8 & 2.4 & 0.0 & 0.5 & 0.0 & 0.5 & 21.8 & 0.0 & 22.4 & 42.9 \\
\hline $846 \mathrm{D}-1 \mathrm{H}-3,148$ & 7.48 & 7.62 & 2.1 & 1.2 & 0.0 & 0.0 & 0.0 & 1.5 & 11.6 & 0.0 & 24.3 & 53.5 \\
\hline $846 \mathrm{D}-1 \mathrm{H}-4,8$ & 7.58 & 7.71 & 1.7 & 1.7 & 0.0 & 1.2 & 1.0 & 2.4 & 14.5 & 0.0 & 12.3 & 58.7 \\
\hline $846 \mathrm{D}-1 \mathrm{H}-4,18$ & 7.68 & 7.79 & 1.0 & 4.2 & 0.0 & 0.2 & 0.2 & 1.2 & 17.0 & 1.0 & 15.6 & 55.5 \\
\hline $846 \mathrm{D}-1 \mathrm{H}-4,28$ & 7.78 & 7.88 & 0.8 & 1.7 & 0.0 & 0.4 & 0.4 & 0.0 & 10.0 & 0.0 & 20.3 & 61.0 \\
\hline $846 \mathrm{D}-1 \mathrm{H}-4,38$ & 7.88 & 7.96 & 1.6 & 1.9 & 0.0 & 0.0 & 0.2 & 0.9 & 9.3 & 0.5 & 26.2 & 56.3 \\
\hline $846 \mathrm{D}-1 \mathrm{H}-4,48$ & 7.98 & 8.03 & 1.8 & 4.0 & 0.0 & 0.9 & 0.7 & 0.9 & 9.9 & 0.2 & 18.7 & 52.2 \\
\hline 846 D- $1 \mathrm{H}-4,58$ & 8.08 & 8.11 & 3.3 & 2.2 & 0.0 & 0.4 & 0.0 & 0.7 & 15.2 & 0.0 & 18.3 & 55.2 \\
\hline
\end{tabular}


APPENDIX (continued).

\begin{tabular}{|c|c|c|c|c|c|c|c|c|c|c|c|c|}
\hline & & & & & & & & ecies & & & & \\
\hline interval $(\mathrm{cm})$ & (mcd) & (rmcd) & O. uni. & G. rub. & $G$, ten. & G. sac. & G. aeq. & G. cal. & G. bul. & G. rbs. & N. $p a . \mathbf{R}$ & N. dut. \\
\hline $846 \mathrm{D}-\mathrm{IH}-4,68$ & 8.18 & 8.19 & 0.8 & 1.5 & 0.0 & 2.3 & 0.4 & 1.2 & 5.0 & 0.0 & 13.0 & 67.3 \\
\hline $846 \mathrm{D}-\mathrm{IH}-4,78$ & 8.28 & 8.26 & 2.5 & 6.6 & 0.0 & 1.2 & 0.8 & 1.2 & 6.2 & 0.0 & 13.0 & 56.3 \\
\hline $846 \mathrm{D}-1 \mathrm{H}-4,88$ & 8.38 & 8.34 & 0.5 & 6.0 & 0.2 & 2.6 & 0.4 & 3.5 & 4.4 & 0.0 & 15.3 & 53.7 \\
\hline $846 \mathrm{D}-\mathrm{IH}-4,98$ & 8.48 & 8.42 & 0.5 & 3.7 & 0.0 & 1.9 & 0.3 & 1.6 & 5.0 & 0.0 & 15.9 & 55.6 \\
\hline 846D-IH-4, 108 & 8.58 & 8.50 & 1.5 & 2.9 & 0.0 & 2.3 & 0.0 & 2.9 & 5.5 & 0.0 & 22.5 & 48.4 \\
\hline $846 \mathrm{D}-1 \mathrm{H}-4,118$ & 8.68 & 8.59 & 2.7 & 2.7 & 0.8 & 2.7 & 0.8 & 1.9 & 3.6 & 0.2 & 22.7 & 50.4 \\
\hline $846 \mathrm{D}-1 \mathrm{H}-4,128$ & 8.78 & 8.68 & 1.1 & 5.5 & 0.0 & 2.2 & 0.4 & 0.7 & 9.9 & 0.4 & 29.0 & 39.8 \\
\hline $846 \mathrm{D}-1 \mathrm{H}-4,138$ & 8.88 & 8.77 & 0.8 & 2.8 & 0.5 & 0.5 & 0.5 & 1.3 & 15.2 & 0.3 & 17.0 & 54.6 \\
\hline $846 \mathrm{D}-1 \mathrm{H}-4,148$ & 8.98 & 8.86 & 1.7 & 2.9 & 0.5 & 1.4 & 0.2 & 2.4 & 13.0 & 0.2 & 23.4 & 45.2 \\
\hline $846 \mathrm{D}-1 \mathrm{H}-5,8$ & 9.08 & 8.97 & 0.9 & 1.8 & 0.2 & 0.9 & 0.2 & 1.8 & 13.2 & 0.0 & 18.5 & 49.4 \\
\hline $846 \mathrm{D}-1 \mathrm{H}-5,18$ & 9.18 & 9.08 & 1.6 & 3.1 & 0.2 & 1.3 & 0.2 & 2.7 & 19.3 & 0.2 & 11.2 & 47.4 \\
\hline $846 \mathrm{D}-1 \mathrm{H}-5,28$ & 9.28 & 9.19 & 0.7 & 4.9 & 0.3 & 0.7 & 0.0 & 0.7 & 5.2 & 0.0 & 24.9 & 52.4 \\
\hline 846D-IH-5, 38 & 9.38 & 9.29 & 0.9 & 1.7 & 0.0 & 1.3 & 0.0 & 0.4 & 1.3 & 0,0 & 26.8 & 61.7 \\
\hline $846 \mathrm{D}-\mathrm{IH}-5,48$ & 9.48 & 9.40 & 0.0 & 2.2 & 0.7 & 2.5 & 0.0 & 2.2 & 5.4 & 0.0 & 21.3 & 58.2 \\
\hline 846 D-IH- 5,58 & 9.58 & 9.49 & 1.2 & 5.0 & 0.0 & 3.1 & 0.2 & 1.7 & 3.4 & 0.0 & 27.0 & 49.2 \\
\hline $846 \mathrm{D}-\mathrm{IH}-5,68$ & 9.68 & 9.59 & 1.8 & 3.6 & 0.3 & 2.0 & 1.0 & 1.0 & 6.9 & 0.0 & 29.6 & 43.2 \\
\hline $846 \mathrm{D}-1 \mathrm{H}-5,78$ & 9.78 & 9.68 & 2.6 & 3.8 & 0.0 & 0.9 & 0.4 & 1.3 & 7.7 & 0.2 & 30.9 & 47.0 \\
\hline 846D-IH-5, 88 & 9.88 & 9.78 & 1.0 & 1.0 & 0.2 & 0.7 & 0.2 & 0.0 & 9.7 & 0.0 & 35.4 & 47.8 \\
\hline 846D-IH-5, 98 & 9.98 & 9.87 & 1.4 & 2.1 & 0.2 & 0.0 & 0.2 & 0.2 & 10.4 & 0.2 & 28.8 & 51.6 \\
\hline $846 \mathrm{D}-1 \mathrm{H}-5,108$ & 10.08 & 9.96 & 1.2 & 0.8 & 0.0 & 0.4 & 0.4 & 0.4 & 15.0 & 0.0 & 25.0 & 48.9 \\
\hline 846D-IH- 5,118 & 10.18 & 10.06 & 0.8 & 0.0 & 0.0 & 0.2 & 0.0 & 1.0 & 9.2 & 0.2 & 35.2 & 50.0 \\
\hline $846 \mathrm{D}-1 \mathrm{H}-5,128$ & 10.28 & 10.16 & 2.1 & 1.9 & 0.3 & 0.0 & 0.0 & 1.9 & 11.2 & 0.0 & 31.4 & 47.3 \\
\hline $846 \mathrm{D}-1 \mathrm{H}-5,138$ & 10.38 & 10.27 & 0.9 & 1.4 & 0.0 & 0.0 & 0.0 & 0.2 & 10.8 & 0.0 & 28.9 & 54.8 \\
\hline $846 \mathrm{D}-1 \mathrm{H}-5,148$ & 10.48 & 10.38 & 0.0 & 2.1 & 0.0 & 0.0 & 0.0 & 1.2 & 10.7 & 0.0 & 22.2 & 58.0 \\
\hline $846 \mathrm{D}-\mathrm{IH}-6,8$ & 10.58 & 10.49 & 0.7 & 1.1 & 0.2 & 0.0 & 0.0 & 1.4 & 9.9 & 0.2 & 23.6 & 57.6 \\
\hline $846 \mathrm{~B}-2 \mathrm{H}-3,8$ & 10.68 & 10.55 & 2.1 & 0.6 & 0.0 & 0.0 & 0.3 & 0.0 & 20.4 & 0.0 & 33.9 & 48.8 \\
\hline 846D-JH-6, 18 & 10.68 & 10.61 & 2.1 & 1.8 & 0.0 & 0.6 & 0.0 & 2.1 & 21.1 & 0.0 & 22.5 & 46.2 \\
\hline $846 \mathrm{~B}-2 \mathrm{H}-3,19$ & 10.79 & 10.70 & 0.7 & 1.8 & 0.0 & 0.0 & 0.2 & 0.0 & 22.5 & 0.0 & 24.2 & 57.9 \\
\hline $846 \mathrm{~B}-2 \mathrm{H}-3,29$ & 10.89 & 10.89 & 2.1 & 1.0 & 0.0 & 0.0 & 0.0 & 0.5 & 20.8 & 0.3 & 25.2 & 57.1 \\
\hline $846 \mathrm{~B}-2 \mathrm{H}-3,38$ & 10.98 & 11.02 & 2.9 & 1.2 & 0.0 & 0.0 & 0.0 & 0.0 & 7.3 & 0.0 & 30.9 & 63.3 \\
\hline $846 \mathrm{~B}-2 \mathrm{H}-3,48$ & 11.08 & 11.12 & 4.3 & 4.0 & 0.0 & 0.3 & 0.0 & 0.0 & 9.3 & 0.8 & 19.1 & 67.5 \\
\hline $846 \mathrm{~B}-2 \mathrm{H}-3,58$ & 11.18 & 11.20 & 3.4 & 2.7 & 0.0 & 1.2 & 0.0 & 0.3 & 8.1 & 0.2 & 19.6 & 70.9 \\
\hline 846 B- $2 \mathrm{H}-3,68$ & 11.28 & 11.28 & 2.2 & 3.6 & 0.0 & 0.5 & 0.0 & 0.0 & 9.8 & 0.0 & 19.7 & 68.6 \\
\hline $846 \mathrm{~B}-2 \mathrm{H}-3,77$ & 11.37 & 11.36 & 2.7 & 1.0 & 0.0 & 0.2 & 0.0 & 0.6 & 9.2 & 0.0 & 21.8 & 71.7 \\
\hline $846 \mathrm{~B}-2 \mathrm{H}-3,88$ & 11.48 & 11.48 & 0.8 & 0.5 & 0.3 & 0.8 & 0.2 & 0.3 & 8.9 & 0.0 & 32.8 & 64.3 \\
\hline $846 \mathrm{~B}-2 \mathrm{H}-3,96$ & 11.56 & 11.58 & 2.5 & 1.1 & 0.0 & 0.0 & 0.0 & 0.0 & 6.1 & 0.0 & 23.9 & 74.1 \\
\hline $846 \mathrm{~B}-2 \mathrm{H}-3,107$ & 11.67 & 11.69 & 0.7 & 0.2 & 0.0 & 0.0 & 0.2 & 0.0 & 8.3 & 0.2 & 24.6 & 75.5 \\
\hline $846 \mathrm{~B}-2 \mathrm{H}-3,118$ & 11.78 & 11.80 & 1.6 & 1.6 & 0.0 & 0.3 & 0.0 & 0.9 & 4.4 & 0.0 & 18.7 & 80.8 \\
\hline $846 \mathrm{~B}-2 \mathrm{H}-3,128$ & 11.88 & 11.88 & 1.3 & 1.9 & 0.0 & 0.3 & 0.0 & 0.3 & 5.8 & 0.3 & 21.6 & 73.8 \\
\hline $846 \mathrm{~B}-2 \mathrm{H}-3,137$ & 11.97 & 11.95 & 2.1 & 2.3 & 0.0 & 0.0 & 0.0 & 0.2 & 8.5 & 0.2 & 25.9 & 67.3 \\
\hline $846 \mathrm{~B}-2 \mathrm{H}-3,148$ & 12.08 & 12.03 & 0.4 & 3.3 & 0.0 & 0.0 & 0.0 & 0.4 & 4.4 & 0.0 & 28.1 & 69.6 \\
\hline $846 \mathrm{~B}-2 \mathrm{H}-4,3$ & 12.13 & 12.09 & 1.1 & 1.1 & 0.0 & 0.0 & 0.0 & 0.7 & 7.4 & 0.4 & 27.5 & 68.1 \\
\hline $846 \mathrm{~B}-2 \mathrm{H}-4,13$ & 12.23 & 12.19 & 0.6 & 3.7 & 0.0 & 0.6 & 0.3 & 0.9 & 10.7 & 0.0 & 28.3 & 60.2 \\
\hline $846 \mathrm{~B}-2 \mathrm{H}-4,23$ & 12.33 & 12.31 & 1.0 & 2.0 & 0.0 & 1.3 & 0.0 & 0.0 & 5.7 & 0.3 & 26.0 & 64.4 \\
\hline $846 \mathrm{~B}-2 \mathrm{H}-4,31$ & 12.41 & 12.42 & 0.3 & 3.3 & 0.0 & 1.1 & 0.5 & 0.5 & 6.9 & 0.3 & 20.6 & 72.8 \\
\hline $846 \mathrm{~B}-2 \mathrm{H}-4,4 \mathrm{I}$ & 12.51 & 12.53 & 1.4 & 5.0 & 0.5 & 0.7 & 0.0 & 0.9 & 10.4 & 0.2 & 22.5 & 58.9 \\
\hline $846 \mathrm{~B}-2 \mathrm{H}-4,54$ & 12.64 & 12.65 & 0.6 & 3.4 & 1.1 & 1.7 & 0.0 & 2.3 & 10.7 & 0.0 & 7.1 & 52.5 \\
\hline $846 \mathrm{~B}-2 \mathrm{H}-4,54$ & 12.64 & 12.65 & 3.0 & 4.2 & 0.6 & 4.2 & 0.6 & 2.4 & 9.1 & 0.0 & 7.4 & 52.7 \\
\hline $846 \mathrm{~B}-2 \mathrm{H}-4,62$ & 12.72 & 12.72 & 1.4 & 6.5 & 0.9 & 1.9 & 0.2 & 3.3 & 8.1 & 0.7 & 10.9 & 49.8 \\
\hline $846 \mathrm{~B}-2 \mathrm{H}-4.73$ & 12.83 & 12.81 & 0.7 & 3.5 & 0.2 & 0.5 & 0.5 & 1.5 & 10.0 & 0.5 & 16.6 & 53.4 \\
\hline $846 \mathrm{~B}-2 \mathrm{H}-4,87$ & 12.97 & 12.96 & 4.8 & 2.4 & 0.0 & 4.1 & 2.7 & 1.4 & 8.6 & 0.7 & 13.4 & 57.2 \\
\hline $846 \mathrm{~B}-2 \mathrm{H}-4.95$ & 13.05 & 13.05 & 1.0 & 2.5 & 0.0 & 1.7 & 0.5 & 1.0 & 1.7 & 0.7 & 23.6 & 75.7 \\
\hline $846 \mathrm{~B}-2 \mathrm{H}-4,106$ & 13.16 & 13.18 & 1.0 & 1.8 & 0.0 & 0.3 & 0.0 & 1.8 & 4.6 & 0.8 & 18.2 & 80.2 \\
\hline $846 \mathrm{~B}-2 \mathrm{H}-4.117$ & 13.27 & 13.29 & 1.4 & 1.4 & 0.3 & 0.5 & 0.2 & 0.7 & 8.9 & 0.2 & 22.6 & 72.4 \\
\hline $846 \mathrm{~B}-2 \mathrm{H}-4,126$ & 13.36 & 13.37 & 0.6 & 0.8 & 0.0 & 0.3 & 0.2 & 0.9 & 10.4 & 0.0 & 29.7 & 70.3 \\
\hline $846 \mathrm{~B}-2 \mathrm{H}-4,136$ & 13.46 & 13.46 & 0.4 & 0.4 & 0.0 & 1.1 & 0.0 & 0.7 & 12.1 & 0.0 & 27.6 & 67.3 \\
\hline $846 \mathrm{~B}-2 \mathrm{H}-4,144$ & 13.54 & 13.54 & 1.3 & 2.9 & 0.0 & 0.3 & 0.0 & 1.0 & 12.2 & 0.0 & 24.2 & 66.2 \\
\hline $846 \mathrm{C}-2 \mathrm{H}-2,58$ & 13.61 & 13.67 & 0.7 & 1.8 & 0.0 & 0.7 & 0.0 & 1.8 & 9.7 & 0.0 & 31.0 & 62.1 \\
\hline $846 \mathrm{C}-2 \mathrm{H}-2,68$ & 13.71 & 13.78 & 0.3 & 0.0 & 0.0 & 0.0 & 0.0 & 1.5 & 13.3 & 0.0 & 25.6 & 68.9 \\
\hline $846 \mathrm{C}-2 \mathrm{H}-2,78$ & 13.81 & 13.86 & 0.0 & 0.0 & 0.0 & 0.5 & 0.0 & 2.6 & 21.8 & 0.3 & 18.8 & 60.3 \\
\hline $846 \mathrm{C}-2 \mathrm{H}-2,88$ & 13.91 & 13.92 & 0.2 & 2.0 & 0.2 & 0.4 & 0.2 & 2.6 & 28.4 & 0.0 & 21.3 & 48.8 \\
\hline $846 \mathrm{C}-2 \mathrm{H}-2,98$ & 14.01 & 13.97 & 1.7 & 1.4 & 0.0 & 0.3 & 0.0 & 0.9 & 17.1 & 0.0 & 21.3 & 64.6 \\
\hline $846 \mathrm{C}-2 \mathrm{H}-2,108$ & 14.11 & 14.03 & 4.0 & 0.5 & 0.0 & 0.0 & 0.3 & 2.4 & 17.2 & 0.0 & 24.3 & 56.6 \\
\hline $846 \mathrm{C}-2 \mathrm{H}-2,118$ & 14.21 & 14.09 & 0.8 & 1.3 & 0.0 & 2.1 & 0.3 & 1.8 & 17.5 & 0.3 & 19.6 & 64.4 \\
\hline $846 \mathrm{C}-2 \mathrm{H}-2,128$ & 14.31 & 14.18 & 1.0 & 1.3 & 0.0 & 0.3 & 0.3 & 0.8 & 21.4 & 0.0 & 19.7 & 62.4 \\
\hline $846 \mathrm{C}-2 \mathrm{H}-2,138$ & 14.41 & 14.29 & 1.0 & 1.3 & 0.0 & 1.0 & 0.3 & 0.7 & 16.3 & 0.3 & 16.7 & 68.7 \\
\hline $846 \mathrm{C}-2 \mathrm{H}-2,148$ & 14.51 & 14.45 & 1.2 & 1.9 & 0.0 & 0.4 & 0.0 & 0.4 & 17.7 & 0.0 & 18.2 & 68.4 \\
\hline $846 \mathrm{C}-2 \mathrm{H}-3,8$ & 14.61 & 14.59 & 0.6 & 0.9 & 0.0 & 0.9 & 1.1 & 0.6 & 22.6 & 0.4 & 13.5 & 61.5 \\
\hline $846 \mathrm{C}-2 \mathrm{H}-3,18$ & 14.71 & 14.69 & 6.0 & 2.0 & 0.0 & 1.2 & 0.0 & 0.0 & 20.6 & 0.0 & 12.7 & 59.7 \\
\hline $846 \mathrm{C}-2 \mathrm{H}-3,28$ & 14.81 & 14.78 & 4.3 & 2.3 & 0.4 & 2.7 & 0.8 & 0.8 & 11.6 & 0.4 & 18.3 & 60.5 \\
\hline $846 \mathrm{C}-2 \mathrm{H}-3,38$ & 14.91 & 14.86 & 2.4 & 1.4 & 0.0 & 1.4 & 0.0 & 2.1 & 10.8 & 0.0 & 19.5 & 62.9 \\
\hline $846 \mathrm{C}-2 \mathrm{H}-3,48$ & 15.01 & 14.95 & 1.6 & 3.4 & 0.5 & 0.0 & 0.0 & 2.4 & 10.0 & 0.0 & 14.7 & 64.2 \\
\hline $846 \mathrm{C}-2 \mathrm{H}-3,58$ & 15.11 & 15.05 & 2.4 & 3.2 & 0.3 & 1.9 & 0.0 & 1.3 & 6.6 & 0.3 & 14.4 & 67.0 \\
\hline $846 \mathrm{C}-2 \mathrm{H}-3,68$ & 15.21 & 15.17 & 1.9 & 2.6 & 0.0 & 1.9 & 0.3 & 1.3 & 8.8 & 0.0 & 14.6 & 72.1 \\
\hline $846 \mathrm{C}-2 \mathrm{H}-3,78$ & 15.31 & 15.31 & 1.7 & 3.4 & 0.0 & 0.4 & 0.0 & 1.3 & 8.1 & 0.4 & 9.4 & 62.3 \\
\hline $846 \mathrm{C}-2 \mathrm{H}-3,8$ & 15.48 & 15.41 & 2.3 & 3.4 & 0.0 & 0.0 & 0.0 & 1.7 & 4.5 & 0.0 & 4.4 & 50.3 \\
\hline $846 \mathrm{D}-2 \mathrm{H}-1,88$ & 15.41 & 15.46 & 1.8 & 4.0 & 0.0 & 2.4 & 0.4 & 2.0 & 10.2 & 0.0 & 5.8 & 55.8 \\
\hline $846 \mathrm{C}-2 \mathrm{H}-3,18$ & 15.58 & 15.52 & 1.9 & 4.5 & 0.0 & 3.0 & 0.4 & 0.7 & 7.8 & 0.7 & 3.1 & 42.9 \\
\hline $846 \mathrm{D}-2 \mathrm{H}-1.98$ & 15.51 & 15.56 & 2.2 & 2.0 & 0.0 & 2.5 & 0.2 & 1.7 & 7.7 & 0.2 & 2.8 & 39.5 \\
\hline $846 \mathrm{D}-2 \mathrm{H}-1,28$ & 15.68 & 15.63 & 1.3 & 3.7 & 1.6 & 7.1 & 1.3 & 0.5 & 7.1 & 0.5 & 3.8 & 37.0 \\
\hline $846 \mathrm{D}-2 \mathrm{H}-\mathrm{I}, 38$ & 15.78 & 15.74 & 2.1 & 3.2 & 0.4 & 3.8 & 0.6 & 1.5 & 5.5 & 0.0 & 3.0 & 40.3 \\
\hline $846 \mathrm{D}-2 \mathrm{H}-1,48$ & 15.88 & 15.84 & 2.2 & 4.6 & 1.1 & 5.2 & 0.5 & 0.5 & 6.8 & 0.5 & 5.5 & 38.1 \\
\hline $846 \mathrm{D}-2 \mathrm{H}-1,58$ & 15.98 & 15.95 & 1.0 & 3.2 & 0.5 & 2.2 & 1.0 & 0.7 & 5.6 & 0.2 & 7.9 & 42.4 \\
\hline
\end{tabular}


APPENDIX (continued).

\begin{tabular}{|c|c|c|c|c|c|c|c|c|c|c|c|c|}
\hline & Shipboard & Revised & & & & & & ecies & & & & \\
\hline interval $(\mathrm{cm})$ & (mcd) & (rmed) & O. uni. & G. rub. & G.ten. & G. sac. & G. aeq. & G. cal. & G. bul. & G. $r b s$. & N.pa. $\mathbf{R}$ & N. dut. \\
\hline $846 \mathrm{D}-2 \mathrm{H}-1,68$ & 16.08 & 16.06 & 1.1 & 3.5 & 0.7 & 4.0 & 0.5 & 1.3 & 4.7 & 0.0 & 13.3 & 32.4 \\
\hline $846 \mathrm{D}-2 \mathrm{H}-1,78$ & 16.17 & 16.16 & 0.6 & 4.5 & 1.7 & 2.8 & 0.6 & 2.0 & 4.0 & 0.8 & 8.7 & 41.2 \\
\hline $846 \mathrm{D}-2 \mathrm{H}-1,88$ & 16.27 & 16.26 & 3.1 & 2.6 & 0.4 & 3.9 & 0.4 & 0.7 & 5.2 & 0.2 & 7.3 & 50.9 \\
\hline $846 \mathrm{D}-2 \mathrm{H}-2,8$ & 16.40 & 16.40 & 1.6 & 1.1 & 0.8 & 1.9 & 0.0 & 0.8 & 6.7 & 1.1 & 12.8 & 68.7 \\
\hline $846 \mathrm{D}-2 \mathrm{H}-2,18$ & 16.51 & 16.51 & 1.8 & i.1 & 0.0 & 0.8 & 0.0 & 1.1 & 6.8 & 0.0 & 14.3 & 75.5 \\
\hline $846 \mathrm{D}-2 \mathrm{H}-2,28$ & 16.60 & 16.60 & 5.2 & 1.5 & 0.2 & 0.9 & 0.2 & 0.4 & 12.5 & 0.0 & 15.1 & 71.6 \\
\hline $846 \mathrm{D}-2 \mathrm{H}-2,38$ & 16.70 & 16.70 & 2.6 & 2.4 & 0.0 & 2.0 & 0.0 & 0.7 & 11.6 & 0.2 & 17.3 & 73.5 \\
\hline $846 \mathrm{D}-2 \mathrm{H}-2,48$ & 16.81 & 16.82 & 4.3 & 1.8 & 0.0 & 0.8 & 0.0 & 1.2 & 12.5 & 0.0 & 12.6 & 66.9 \\
\hline $846 \mathrm{D}-2 \mathrm{H}-2,58$ & 16.90 & 16.91 & 4.0 & 3.0 & 0.0 & 1.1 & 0.0 & 0.0 & 14.0 & 0.0 & 19.2 & 61.6 \\
\hline $846 \mathrm{D}-2 \mathrm{H}-2,68$ & 17.01 & 17.02 & 4.5 & 1.3 & 0.3 & 0.3 & 0.0 & 0.8 & 8.0 & 0.0 & 17.5 & 78.2 \\
\hline $846 \mathrm{D}-2 \mathrm{H}-2,78$ & 17.10 & 17.10 & 2.2 & 1.6 & 0.0 & 0.3 & 0.0 & 2.2 & 7.3 & 0.6 & 19.2 & 75.4 \\
\hline $846 \mathrm{D}-2 \mathrm{H}-2,88$ & 17.20 & 17.20 & 3.0 & 1.1 & 0.0 & 1.9 & 0.0 & 0.3 & 8.6 & 0.0 & 20.4 & 75.7 \\
\hline $846 \mathrm{D}-2 \mathrm{H}-2,98$ & 17.31 & 17.31 & 2.4 & 0.7 & 0.0 & 2.4 & 1.7 & 0.2 & 11.1 & 0.0 & 15.8 & 73.2 \\
\hline $846 \mathrm{D}-2 \mathrm{H}-2,108$ & 17.40 & 17.40 & 2.4 & 0.9 & 0.0 & 1.6 & 1.4 & 0.0 & 12.6 & 0.0 & 16.7 & 73.0 \\
\hline $846 \mathrm{D}-2 \mathrm{H}-2,118$ & 17.51 & 17.51 & 5.8 & 2.2 & 0.0 & 2.2 & 0.4 & 1.5 & 10.9 & 0.0 & 19.6 & 65.5 \\
\hline $846 \mathrm{D}-2 \mathrm{H}-2,128$ & 17.60 & 17.60 & 4.1 & 0.6 & 0.0 & 0.9 & 0.0 & 0.8 & 11.2 & 0.2 & 15.9 & 73.7 \\
\hline $846 \mathrm{D}-2 \mathrm{H}-2,138$ & 17.70 & 17.70 & 5.1 & 0.4 & 0.4 & 1.1 & 0.0 & 1.1 & 12.0 & 0.0 & 15.3 & 73.1 \\
\hline $846 \mathrm{D}-2 \mathrm{H}-3,8$ & 17.90 & 17.90 & 9.5 & 2.3 & 0.4 & 1.6 & 0.0 & 1.2 & 12.6 & 0.0 & 9.2 & 61.4 \\
\hline $846 \mathrm{D}-2 \mathrm{H}-3,18$ & 18.00 & 17.99 & 3.7 & 2,0 & 0.0 & 0.7 & 0.0 & 1.0 & 12.0 & 0.0 & 9.6 & 70.6 \\
\hline $846 \mathrm{D}-2 \mathrm{H}-3,28$ & 18.10 & 18.10 & 13.0 & 1.4 & 0.0 & 0.8 & 0.0 & 0.0 & 13.0 & 0.0 & 12.4 & 60.3 \\
\hline $846 \mathrm{D}-2 \mathrm{H}-3,38$ & 18.20 & 18.20 & 7.2 & 1.7 & 0.0 & 0.8 & 0.0 & 1.0 & 9.1 & 0.0 & 13.8 & 74.0 \\
\hline $846 \mathrm{D}-2 \mathrm{H}-3.48$ & 18.30 & 18.29 & 5.6 & 0.9 & 0.2 & 1.1 & 0.0 & 2.0 & 10.5 & 0.0 & 17.4 & 72.2 \\
\hline $846 \mathrm{D}-2 \mathrm{H}-3.58$ & 18.40 & 18.40 & 3.5 & 1.5 & 0.0 & 0.7 & 0.0 & 1.5 & 10.2 & 0.0 & 24.0 & 64.4 \\
\hline $846 \mathrm{D}-2 \mathrm{H}-3,68$ & 18.50 & 18.50 & 3.5 & 1.0 & 0.0 & 0.5 & 0.0 & 0.5 & 7.1 & 0.2 & 20.3 & 72.0 \\
\hline $846 \mathrm{D}-2 \mathrm{H}-3,78$ & 18.60 & 18.60 & 3.9 & 0.9 & 0.0 & 0.9 & 0.3 & 2.1 & 13.6 & 0.0 & 21.3 & 63.7 \\
\hline $846 \mathrm{D}-2 \mathrm{H}-3.88$ & 18.70 & 18.70 & 3.0 & 1.2 & 0.0 & 1.8 & 0.0 & 0.6 & 10.4 & 0.0 & 20.6 & 64.6 \\
\hline $846 \mathrm{D}-2 \mathrm{H}-3,98$ & 18.80 & 18.80 & 3.8 & 4.0 & 0.0 & 3.5 & 1.6 & 0.7 & 13.4 & 0.0 & 3.2 & 47.9 \\
\hline $846 \mathrm{D}-2 \mathrm{H}-3.108$ & 18.90 & 18.90 & 8.7 & 2.0 & 0.0 & 1.4 & 1.1 & 0.3 & 12.9 & 0.0 & 1.8 & 51.0 \\
\hline $846 \mathrm{D}-2 \mathrm{H}-4,8$ & 19.04 & 19.04 & 5.1 & 3.8 & 0.0 & 1.4 & 0.3 & 1.6 & 5.7 & 0.0 & 7.4 & 59.8 \\
\hline $846 \mathrm{D}-2 \mathrm{H}-4,18$ & 19.14 & 19.14 & 4.7 & 1.2 & 0.0 & 2.9 & 0.3 & 1.7 & 3.2 & 0.0 & 8.3 & 60.8 \\
\hline $846 \mathrm{D}-2 \mathrm{H}-4,28$ & 19.24 & 19.24 & 2.1 & 2.6 & 0.0 & 2.6 & 0.5 & 2.3 & 3.1 & 0.0 & 6.1 & 53.9 \\
\hline $846 \mathrm{D}-2 \mathrm{H}-4.38$ & 19.35 & 19.35 & 2.0 & 2.7 & 0.0 & 1.7 & 0.7 & 1.7 & 8.2 & 0.0 & 10.4 & 58.5 \\
\hline $846 \mathrm{D}-2 \mathrm{H}-4,48$ & 19.44 & 19.44 & 1.6 & 4.0 & 0.0 & 3.2 & 0.8 & 1.6 & 2.4 & 0.0 & 9.3 & 50.6 \\
\hline $846 \mathrm{D}-2 \mathrm{H}-4.58$ & 19.54 & 19.54 & 4.9 & 3.5 & 0.2 & 1.4 & 0.4 & 2.6 & 5.3 & 0.0 & 6.7 & 46.1 \\
\hline $846 \mathrm{D}-2 \mathrm{H}-4.68$ & 19.64 & 19.64 & 4.5 & 6.3 & 0.3 & 3.4 & 0.0 & 2.9 & 6.1 & 0.0 & 5.5 & 40.3 \\
\hline $846 \mathrm{D}-2 \mathrm{H}-4,78$ & 19.74 & 19.74 & 3.3 & 5.4 & 0.2 & 2.6 & 0.9 & 4.4 & 6.3 & 0.0 & 6.7 & 48.5 \\
\hline $846 \mathrm{D}-2 \mathrm{H}-4.88$ & 19.85 & 19.85 & 3.1 & 3.1 & 0.0 & 1.0 & 0.0 & 2.0 & 4.1 & 0.0 & 7.8 & 58.7 \\
\hline $846 \mathrm{D}-2 \mathrm{H}-4.98$ & 19.94 & 19.94 & 1.7 & 3.1 & 0.4 & 2.4 & 0.4 & 1.5 & 3.5 & 0.2 & 12.7 & 58.3 \\
\hline $846 \mathrm{D}-2 \mathrm{H}-4.108$ & 20.04 & 20.04 & 3.2 & 3.8 & 0.3 & 4.5 & 0.6 & 2.6 & 4.2 & 0.0 & 9.7 & 57.5 \\
\hline $846 \mathrm{~B}-3 \mathrm{H}-2,8$ & 20.13 & 20.27 & 1.6 & 3.2 & 0.0 & 1.5 & 0.6 & 0.6 & 2.6 & 0.0 & 16.0 & 72.3 \\
\hline $846 \mathrm{~B}-3 \mathrm{H}-2,18$ & 20.22 & 20,35 & 1.7 & 3.1 & 0.0 & 1.7 & 1.0 & 1.4 & 2.2 & 0.0 & 18.7 & 73.7 \\
\hline $846 \mathrm{~B}-3 \mathrm{H}-2,27$ & 20.31 & 20.42 & 2.0 & 2.3 & 0.0 & 2.0 & 1.5 & 0.6 & 4.7 & 0.0 & 20,0 & 67.0 \\
\hline $846 \mathrm{~B}-3 \mathrm{H}-2,37$ & 20.42 & 20.51 & 1.5 & 1.3 & 0.0 & 1.3 & 0.9 & 0.0 & 4.8 & 0.0 & 23.8 & 71.5 \\
\hline $846 \mathrm{~B}-3 \mathrm{H}-2,48$ & 20.53 & 20.60 & 2.8 & 1.8 & 0.0 & 0.4 & 0.2 & 0.6 & 5.7 & 0.0 & 25.4 & 71.1 \\
\hline $846 \mathrm{~B}-3 \mathrm{H}-2,58$ & 20.63 & 20.70 & 1.8 & 0.8 & 0.0 & 0.5 & 0.0 & 1.5 & 6.0 & 0.0 & 32.3 & 63.2 \\
\hline $846 \mathrm{~B}-3 \mathrm{H}-2,69$ & 20.74 & 20.81 & 1.5 & 1.8 & 0.0 & 0.3 & 0.0 & 2.1 & 6.2 & 0.0 & 23.4 & 69.3 \\
\hline $846 \mathrm{~B}-3 \mathrm{H}-2,78$ & 20.84 & 20.92 & 1.7 & 1.5 & 0.0 & 0.2 & 0.0 & 1.3 & 7.9 & 0.2 & 22.1 & 74.9 \\
\hline $846 \mathrm{~B}-3 \mathrm{H}-2,88$ & 20.93 & 21.04 & 3.3 & 2.4 & 0.0 & 0.9 & 0.0 & 1.1 & 3.1 & 0.2 & 20.3 & 77.9 \\
\hline $846 \mathrm{~B}-3 \mathrm{H}-2,109$ & 21.14 & 21.35 & 2.3 & 1.7 & 0.0 & 1.0 & 0.3 & 2.0 & 10.7 & 0.0 & 20.5 & 67.0 \\
\hline $846 \mathrm{~B}-3 \mathrm{H}-2,128$ & 21.33 & 21.56 & 6.2 & 1.2 & 0.0 & 0.5 & 0.5 & 1.5 & 14.9 & 0.0 & 16.5 & 63.4 \\
\hline $846 \mathrm{~B}-3 \mathrm{H}-2,147$ & 21.52 & 21.68 & 5.7 & 2.2 & 0.0 & 3.8 & 1.1 & 3.8 & 4.9 & 0.0 & 15.5 & 65.7 \\
\hline $846 \mathrm{~B}-3 \mathrm{H}-3,18$ & 21.73 & 21.83 & 1.4 & 3.5 & 0.0 & 4.9 & 0.3 & 1.4 & 6.6 & 0.0 & 14.9 & 66.2 \\
\hline $846 \mathrm{~B}-3 \mathrm{H}-3,36$ & 21.90 & 21.99 & 2.3 & 2.3 & 0.3 & 1.9 & 0.3 & 1.3 & 5.2 & 0.0 & 15.9 & 60.5 \\
\hline $846 \mathrm{~B}-3 \mathrm{H}-3,58$ & 22.13 & 22.26 & 5.8 & 3.7 & 0.0 & 1.1 & 0.5 & 1.1 & 12.9 & 0.0 & 19.5 & 44.7 \\
\hline $846 \mathrm{~B}-3 \mathrm{H}-3,77$ & 22.32 & 22.49 & 3.0 & 2.5 & 0.2 & 2.5 & 0.2 & 2.5 & 11.2 & 0.0 & 12.6 & 60.0 \\
\hline $846 \mathrm{~B}-3 \mathrm{H}-3,99$ & 22.54 & 22.71 & 1.2 & 6.9 & 0.0 & 2.3 & 1.2 & 1.5 & 3.8 & 0.0 & 15.9 & 59.2 \\
\hline $846 \mathrm{~B}-3 \mathrm{H}-3,118$ & 22.73 & 22.87 & 3.0 & 3.0 & 0.9 & 4.3 & 0.0 & 4.8 & 3.9 & 0.0 & 3,1 & 41.6 \\
\hline $846 \mathrm{~B}-3 \mathrm{H}-3,137$ & 22.92 & 23.02 & 3.9 & 3.9 & 0.6 & 3.2 & 0.0 & 2.0 & 8.7 & 0.0 & 12.1 & 46.9 \\
\hline $846 \mathrm{~B}-3 \mathrm{H}-4,3$ & 23.08 & 23.14 & 1.3 & 4.7 & 0.2 & 2.1 & 0.6 & 3.0 & 5.8 & 0.0 & 18.6 & 55.7 \\
\hline $846 \mathrm{~B}-3 \mathrm{H}-4,23$ & 23.28 & 23.30 & 2.3 & 2.8 & 0.2 & 1.4 & 0.2 & 0.9 & 6.9 & 0.2 & 25.7 & 61.4 \\
\hline $846 \mathrm{~B}-3 \mathrm{H}-4.44$ & 23.49 & 23.48 & 1.8 & 2.0 & 0.6 & 0.6 & 0.4 & 0.6 & 7.8 & 0.0 & 27.7 & 60.4 \\
\hline $846 \mathrm{~B}-3 \mathrm{H}-4,62$ & 23.67 & 23.65 & 9.8 & 2.3 & 0.3 & 1.0 & 0.0 & 1.0 & 13.1 & 0.0 & 28.2 & 43.6 \\
\hline $846 \mathrm{~B}-3 \mathrm{H}-4.79$ & 23.84 & 23.83 & 5.4 & 3.4 & 0.3 & 1.2 & 0.2 & 0.3 & 12.7 & 0.0 & 24.6 & 50.3 \\
\hline $846 \mathrm{~B}-3 \mathrm{H}-4,103$ & 24.08 & 24.08 & 2.9 & 1.3 & 0.0 & 0.3 & 0.0 & 0.0 & 16.4 & 0.0 & 15.8 & 63.3 \\
\hline $846 \mathrm{~B}-3 \mathrm{H}-4,125$ & 24.30 & 24.30 & 4.2 & 4.4 & 0.2 & 0.4 & 0.0 & 0.8 & 10.3 & 0.0 & 12.4 & 37.2 \\
\hline $846 \mathrm{~B}-3 \mathrm{H}-4,145$ & 24.49 & 24.48 & 5.3 & 3.5 & 0.0 & 1.8 & 0.4 & 2.5 & 16.5 & 0.0 & 16.1 & 37.5 \\
\hline $846 \mathrm{~B}-3 \mathrm{H}-5,18$ & 24.73 & 24.71 & 10.2 & 3.7 & 0.0 & 1.4 & 0.4 & 1.0 & 15.1 & 0.0 & 24.9 & 38.7 \\
\hline $846 \mathrm{D}-3 \mathrm{H}-1,48$ & 25.17 & 25.07 & 7.9 & 4.3 & 0.2 & 2.2 & 0.8 & 0.6 & 16.2 & 0.0 & 20.3 & 46.6 \\
\hline $846 \mathrm{D}-3 \mathrm{H}-1.68$ & 25.37 & 25.30 & 5.2 & 6.4 & 0.8 & 2.8 & 0.0 & 0.4 & 8.4 & 0.0 & 18.9 & 39.6 \\
\hline $846 \mathrm{D}-3 \mathrm{H}-1.88$ & 25.58 & 25.42 & 3.3 & 4.3 & 1.7 & 1.7 & 0.0 & 0.5 & 7.1 & 0.0 & 12.7 & 39.2 \\
\hline $846 \mathrm{D}-3 \mathrm{H}-1,108$ & 25.78 & 25.48 & 9.6 & 3.8 & 0.8 & 0.4 & 0.4 & 1.9 & 5.4 & 0.0 & 26.1 & 46.0 \\
\hline $846 \mathrm{D}-3 \mathrm{H}-1,128$ & 25.98 & 25.54 & 3,2 & 2.9 & 0.6 & 1.4 & 0.3 & 1.4 & 6.3 & 0.3 & 27.8 & 51.3 \\
\hline $846 \mathrm{D}-3 \mathrm{H}-\mathrm{J}, 148$ & 26.17 & 25.69 & 4.2 & 4.2 & 0.7 & 6.0 & 2.9 & 2.9 & 10.0 & 0.0 & 13.1 & 37.1 \\
\hline $846 \mathrm{D}-3 \mathrm{H}-2,18$ & 26.37 & 26.21 & 4.7 & 2.3 & 0.3 & 15 & 0.9 & 2.0 & 15.4 & 0.0 & 23.3 & 41.3 \\
\hline $846 \mathrm{D}-3 \mathrm{H}-2,48$ & 26.67 & 26.46 & 3.5 & 1.3 & 0.4 & 1.3 & 0.0 & 0.9 & 16.5 & 0.4 & 34.9 & 38.7 \\
\hline $846 \mathrm{~B}-1 \mathrm{H}-1,12$ & 0.12 & 0.12 & 0.3 & 0.8 & 0.8 & 0.0 & 4.1 & 0.0 & 3.3 & 367 & 32.1 & 2.9 \\
\hline $846 \mathrm{~B}-1 \mathrm{H}-1.24$ & 0.24 & 0.24 & 0.6 & 0.6 & 0.0 & 0.0 & 3.4 & 0.0 & 2.3 & 350 & 19.2 & 3.6 \\
\hline $846 \mathrm{~B}-1 \mathrm{H}-1.33$ & 0.33 & 0.33 & 0.3 & 0.0 & 0.3 & 0.0 & 3.6 & 0.0 & 1.1 & 358 & 9.2 & 1.9 \\
\hline $846 \mathrm{~B}-1 \mathrm{H}-1,43$ & 0.43 & 0.43 & 0.2 & 0.0 & 0.0 & 0.0 & 4.1 & 0.0 & 4.3 & 41 & 7.4 & 1.4 \\
\hline $846 \mathrm{~B}-1 \mathrm{H}-1,53$ & 0.53 & 0.53 & 0.3 & 0.3 & 1.7 & 0.3 & 3.7 & 0.0 & 2.7 & 299 & 8.6 & 2.3 \\
\hline $846 \mathrm{~B}-1 \mathrm{H}-1.63$ & 0.63 & 0.63 & 0.2 & 0.2 & 2.8 & 0.0 & 1.9 & 0.0 & 1.9 & 422 & 7.2 & 1.2 \\
\hline $846 \mathrm{~B}-1 \mathrm{H}-1,73$ & 0.73 & 0.73 & 0.0 & 0.0 & 16.2 & 0.0 & 4.2 & 0.3 & 2.8 & 357 & 14.5 & 1.9 \\
\hline $846 \mathrm{~B}-1 \mathrm{H}-1,88$ & 0.88 & 0.88 & 0.0 & 0.2 & 16.2 & 0.0 & 2.4 & 0.2 & 3.5 & 425 & 13.3 & 2.5 \\
\hline
\end{tabular}


APPENDIX (continued).

\begin{tabular}{|c|c|c|c|c|c|c|c|c|c|c|c|c|}
\hline & & & & & & & & ecies & & & & \\
\hline interval $(\mathrm{cm})$ & (mcd) & (rmcd) & O. uni. & G. rub. & G.ten. & G. sac. & G. aeq. & G. cal. & G. bul. & G. rbs. & N. pa. $\mathrm{R}$ & N. dut. \\
\hline $846 \mathrm{~B}-1 \mathrm{H}-\mathrm{I}, 100$ & 1.00 & 1.00 & 0.0 & 0.3 & 9.5 & 0.0 & 3.1 & 0.0 & 1.5 & 326 & 15.7 & 3.8 \\
\hline $846 \mathrm{~B}-1 \mathrm{H}-1,113$ & 1.13 & 1.13 & 0.2 & 0.4 & 23.6 & 0.0 & 2.5 & 0.4 & 1.3 & 445 & 11.1 & 2.2 \\
\hline $846 \mathrm{~B}-1 \mathrm{H}-1,124$ & 1.23 & 1.23 & 0.0 & 0.0 & 23.3 & 0.0 & 2.5 & 0.0 & 4.7 & 322 & 11.8 & 3.0 \\
\hline $846 \mathrm{~B}-1 \mathrm{H}-1,133$ & 1.33 & 1.33 & 0.0 & 0.0 & 41.1 & 0.0 & 2.7 & 0.5 & 3.7 & 219 & 11.0 & 3.5 \\
\hline $846 \mathrm{~B}-1 \mathrm{H}-\mathrm{I}, 145$ & 1.44 & 1.44 & 0.0 & 0.2 & 35.4 & 0.0 & 2.9 & 0.0 & 1.6 & 443 & 9.6 & 3.7 \\
\hline $846 \mathrm{~B}-1 \mathrm{H}-2,9$ & 1.59 & 1.59 & 0.0 & 0.0 & 25.4 & 0.0 & 1.6 & 0.0 & 2.2 & 315 & 11.0 & 1.9 \\
\hline $846 \mathrm{~B}-1 \mathrm{H}-2,19$ & 1.68 & 1.68 & 0.0 & 0.0 & 7.5 & 0.0 & 2.6 & 0.0 & 1.5 & 455 & 8.8 & 3.4 \\
\hline $846 \mathrm{~B}-1 \mathrm{H}-2,29$ & 1.79 & 1.79 & 0.0 & 0.0 & 4.9 & 0.0 & 3.1 & 0.7 & 1.7 & 288 & 8.3 & 1.7 \\
\hline $846 \mathrm{~B}-\mathrm{IH}-2,37$ & 1.87 & 1.87 & 0.0 & 0.2 & 0.4 & 0.0 & 3.4 & 0.0 & 3.7 & 536 & 7.3 & 2.2 \\
\hline $846 \mathrm{~B}-1 \mathrm{H}-2,48$ & 1.98 & 1.98 & 0.0 & 0.0 & 0.0 & 0.0 & 4.8 & 0.0 & 3.7 & 377 & 9.9 & 1.6 \\
\hline $846 \mathrm{~B}-1 \mathrm{H}-2,57$ & 2.07 & 2.07 & 0.0 & 0.0 & 0.0 & 0.0 & 4.7 & 0.0 & 5.0 & 444 & 11.0 & 6.9 \\
\hline 846B-1H-2, 68 & 2.17 & 2.17 & 0.0 & 0.0 & 0.0 & 0.0 & 3.1 & 0.0 & 7.2 & 223 & 9.2 & 5.1 \\
\hline $846 \mathrm{~B}-\mathrm{IH}-2,78$ & 2.28 & 2.28 & 0.0 & 0.0 & 0.0 & 0.0 & 1.8 & 0.0 & 7.3 & 455 & 10.3 & 1.9 \\
\hline $846 \mathrm{~B}-1 \mathrm{H}-2,88$ & 2.38 & 2.38 & 0.0 & 0.0 & 0.0 & 0.0 & 2.3 & 0.0 & 3.6 & 384 & 8.8 & 3.0 \\
\hline $846 \mathrm{~B}-1 \mathrm{H}-2,97$ & 2.47 & 2.47 & 0.0 & 0.0 & 0.0 & 0.0 & 2.8 & 0.0 & 4.7 & 427 & 5.8 & 1.2 \\
\hline 846B-IH-2, 109 & 2.59 & 2.59 & 0.0 & 0.0 & 0.0 & 0.0 & 3.4 & 0.0 & 3.4 & 322 & 3.6 & 1.2 \\
\hline $846 \mathrm{~B}-1 \mathrm{H}-2,117$ & 2.67 & 2.67 & 0.0 & 0.0 & 0.0 & 0.0 & 0.7 & 0.0 & 2.2 & 415 & 3.3 & 1.4 \\
\hline $846 \mathrm{~B}-1 \mathrm{H}-2,128$ & 2.78 & 2.78 & 0.0 & 0.0 & 1.3 & 0.4 & 1.3 & 0.0 & 1.8 & 225 & 8.2 & 2.2 \\
\hline $846 \mathrm{~B}-\mathrm{IH}-2,137$ & 2.87 & 2.87 & 0.5 & 0.0 & 0.5 & 0.0 & 3.3 & 0.0 & 3.1 & 426 & 6.6 & 3.8 \\
\hline $846 \mathrm{~B}-1 \mathrm{H}-2,146$ & 2.96 & 2.96 & 0.0 & 0.2 & 1.5 & 0.0 & 3.0 & 0.0 & 3.7 & 406 & 8.2 & 6.7 \\
\hline 846B-IH-3, 9 & 3.09 & 3.09 & 0.0 & 0.2 & 14.7 & 0.0 & 0.6 & 0.0 & 1.8 & 498 & 6.0 & 5.9 \\
\hline $846 \mathrm{~B}-1 \mathrm{H}-3,18$ & 3.18 & 3.18 & 0.0 & 0.0 & 20.6 & 0.0 & 1.9 & 0.0 & 2.3 & 262 & 6.1 & 6.1 \\
\hline $846 \mathrm{~B}-1 \mathrm{H}-3,28$ & 3.28 & 3.28 & 0.0 & 0.4 & 9.5 & 0.0 & 1.6 & 0.0 & 1.6 & 252 & 7.3 & 5.6 \\
\hline $846 \mathrm{~B}-1 \mathrm{H}-3,39$ & 3.39 & 3.39 & 0.0 & 0.2 & 0.4 & 0.0 & 2.0 & 0.4 & 1.3 & 458 & 8.2 & 5.0 \\
\hline $846 \mathrm{~B}-1 \mathrm{H}-3,48$ & 3.48 & 3.48 & 0.2 & 0.2 & 0.0 & 0.0 & 3.2 & 0.4 & 1.2 & 501 & 9.3 & 3.1 \\
\hline 846B-1H-3, 57 & 3.57 & 3.57 & 0.0 & 0.0 & 0.4 & 0.0 & 2.9 & 0.4 & 1.8 & 273 & 4.8 & 1.4 \\
\hline $846 \mathrm{~B}-1 \mathrm{H}-3,67$ & 3.67 & 3.67 & 0.0 & 0.4 & 0.0 & 0.0 & 3.8 & 0.8 & 2.3 & 263 & 11.7 & 3.3 \\
\hline $846 \mathrm{~B}-1 \mathrm{H}-3,78$ & 3.78 & 3.78 & 0.0 & 0.7 & 0.0 & 0.0 & 3.1 & 0.7 & 2.7 & 294 & 13.6 & 3.6 \\
\hline $846 \mathrm{~B}-\mathrm{IH}-3,88$ & 3.88 & 3.88 & 0.0 & 0.0 & 0.0 & 0.0 & 3.1 & 0.0 & 1.9 & 321 & 11.0 & 4.5 \\
\hline 846B-1H-3, 98 & 3.98 & 3.98 & 0.0 & 0.0 & 0.0 & 0.0 & 5.1 & 0.0 & 0.5 & 195 & 12.8 & 4.4 \\
\hline $846 \mathrm{~B}-1 \mathrm{H}-3,108$ & 4.09 & 4.11 & 0.0 & 0.0 & 0.0 & 0.0 & 2.8 & 0.0 & 2.0 & 247 & 11.4 & 3.1 \\
\hline 846B-1H-3, 118 & 4.18 & 4.20 & 0.0 & 0.0 & 0.0 & 0.3 & 4.2 & 0.0 & 2.2 & 358 & 21.6 & 9.4 \\
\hline $846 \mathrm{D}-1 \mathrm{H}-\mathrm{I}, 128$ & 4.28 & 4.29 & 0.0 & 0.5 & 0.0 & 0.0 & 6.1 & 0.0 & 0.9 & 214 & 17.0 & 7.4 \\
\hline $846 \mathrm{~B}-\mathrm{IH}-3,118$ & 4.18 & 4.32 & 0.0 & 0.2 & 0.0 & 0.0 & 6.6 & 0.0 & 3.1 & 423 & 22.5 & 7.6 \\
\hline $846 \mathrm{D}-\mathrm{IH}-\mathrm{I}, 137$ & 4.37 & 4.37 & 0.0 & 0.8 & 0.0 & 0.0 & 7.5 & 0,3 & 2.6 & 387 & 14.4 & 4.7 \\
\hline $846 \mathrm{~B}-\mathrm{IH}-3,128$ & 4.28 & 4.43 & 0.0 & 1.1 & 0.0 & 0.0 & 8.3 & 0.0 & 1.3 & 373 & 20.7 & 7.4 \\
\hline $846 \mathrm{D}-1 \mathrm{H}-1,146$ & 4.46 & 4.46 & 0.0 & 0.2 & 0.0 & 0.0 & 4.3 & 0.2 & 3.4 & 416 & 14.9 & 8.4 \\
\hline $846 \mathrm{~B}-1 \mathrm{H}-3,138$ & 4.38 & 4.54 & 0.0 & 0.7 & 0.2 & 0.0 & 8.0 & 0.2 & 1.9 & 426 & 18.1 & 6.6 \\
\hline 846D-1H-1, 148 & 4.48 & 4.66 & 0.0 & 0.5 & 0.0 & 0.0 & 1.7 & 0.0 & 1.5 & 404 & 7.3 & 3.8 \\
\hline $846 \mathrm{D}-1 \mathrm{H}-2,8$ & 4.58 & 4.78 & 0.0 & 0.3 & 0.0 & 0.0 & 2.4 & 0.0 & 2.1 & 288 & 11.4 & 3.7 \\
\hline $846 \mathrm{D}-1 \mathrm{H}-2,18$ & 4.68 & 4.90 & 0.0 & 0.6 & 0.0 & 0.0 & 6.6 & 0.6 & 2.2 & 181 & 13.8 & 4.7 \\
\hline $846 \mathrm{D}-1 \mathrm{H}-2,28$ & 4.78 & 5.01 & 0.0 & 0.8 & 0.0 & 0.0 & 10.0 & 0.0 & 4.8 & 249 & 11.9 & 1.6 \\
\hline $846 \mathrm{D}-1 \mathrm{H}-2,38$ & 4.88 & 5.12 & 0.9 & 1.4 & 0.0 & 0.0 & 6.8 & 0.9 & 4.5 & 220 & 14.3 & 3.1 \\
\hline $846 \mathrm{D}-1 \mathrm{H}-2,48$ & 4.98 & 5.22 & 0.0 & 0.0 & 0.0 & 0.0 & 4.4 & 0.0 & 7.5 & 320 & 13.7 & 3.3 \\
\hline $846 \mathrm{D}-1 \mathrm{H}-2,78$ & 5.28 & 5.52 & 0.0 & 1.6 & 0.0 & 0.0 & 3.7 & 0.0 & 6.0 & 434 & 8.3 & 2.3 \\
\hline $846 \mathrm{D}-1 \mathrm{H}-2,88$ & 5.38 & 5.62 & 0.0 & 0.5 & 0.0 & 0.0 & 6.2 & 0.0 & 2.9 & 583 & 6.9 & 2.5 \\
\hline $846 \mathrm{D}-1 \mathrm{H}-2,98$ & 5.48 & 5.72 & 0.0 & 0.8 & 0.0 & 1.4 & 6.0 & 0.0 & 4.1 & 366 & 4.5 & 1.9 \\
\hline $846 \mathrm{D}-1 \mathrm{H}-2,108$ & 5.58 & 5.82 & 0.0 & 0.6 & 0.0 & 1.0 & 6.2 & 0.0 & 3.2 & 308 & 5.3 & 1.9 \\
\hline $846 \mathrm{D}-1 \mathrm{H}-2,118$ & 5.68 & 5.92 & 0.0 & 0.5 & 0.0 & 1.1 & 4.3 & 0.0 & 0.7 & 444 & 3.9 & 0.9 \\
\hline 846D-1H-2, 128 & 5.78 & 6.02 & 0.0 & 0.4 & 0.0 & 1.4 & 4.5 & 0.0 & 2.4 & 508 & 4.0 & 1.7 \\
\hline $846 \mathrm{D}-1 \mathrm{H}-2,138$ & 5,88 & 6.13 & 0.0 & 0.0 & 0.0 & 3.1 & 4.5 & 0.2 & 2.0 & 489 & 5.4 & 2.2 \\
\hline 846D-1H-2, 148 & 5.98 & 6.23 & 0.0 & 0.0 & 0.0 & 2.1 & 1.9 & 0.0 & 1.9 & 475 & 4.2 & 2.1 \\
\hline $846 \mathrm{D}-\mathrm{IH}-3,8$ & 6.08 & 6.33 & 0.0 & 0.4 & 0.0 & 1.3 & 2.0 & 0.0 & 0.7 & 554 & 3.5 & 0.0 \\
\hline $846 \mathrm{D}-1 \mathrm{H}-3,18$ & 6.18 & 6.43 & 0.0 & 0.0 & 0.0 & 0.7 & 1.4 & 0.0 & 2.5 & 283 & 2.7 & 1.4 \\
\hline $846 \mathrm{D}-1 \mathrm{H}-3,28$ & 6.28 & 6.53 & 0.0 & 0.6 & 0.0 & 0.4 & 1.7 & 0.0 & 0.6 & 516 & 2.6 & 1.5 \\
\hline $846 \mathrm{D}-1 \mathrm{H}-3,38$ & 6.38 & 6.63 & 0.0 & 0.0 & 0.0 & 0.4 & 2.4 & 0.0 & 2.4 & 249 & 3.2 & 1.2 \\
\hline $846 \mathrm{D}-1 \mathrm{H}-3,48$ & 6.48 & 6.72 & 0.0 & 0.6 & 0.0 & 0.2 & 1.0 & 0.0 & 0.6 & 522 & 2.7 & 1.1 \\
\hline 846D-IH-3, 58 & 6.58 & 6.82 & 0.0 & 0.8 & 0.0 & 0.3 & 0.8 & 0.0 & 2.3 & 389 & 4.4 & 1.3 \\
\hline $846 \mathrm{D}-1 \mathrm{H}-3,68$ & 6.68 & 6.91 & 0.0 & 0.2 & 0.0 & 0.4 & 3.0 & 0.0 & 1.5 & 470 & 3.6 & 1.5 \\
\hline $846 \mathrm{D}-1 \mathrm{H}-3,78$ & 6.78 & 7.00 & 0.0 & 0.0 & 0.0 & 0.0 & 3.4 & 0.0 & 1.9 & 263 & 4.1 & 2.2 \\
\hline $846 \mathrm{D}-1 \mathrm{H}-3,88$ & 6.88 & 7.10 & 0.0 & 0.4 & 0.0 & 0.0 & 4.3 & 0.0 & 2.2 & 506 & 6.1 & 8.0 \\
\hline 846D-1H-3, 98 & 6.98 & 7.18 & 0.0 & 0.0 & 0.0 & 0.0 & 0.6 & 0.0 & 0.6 & 335 & 3.3 & 2.6 \\
\hline $846 \mathrm{D}-1 \mathrm{H}-3,108$ & 7.08 & 7.27 & 0.0 & 0.7 & 0.0 & 0.3 & 1.0 & 0.0 & 0.0 & 290 & 3.2 & 1.7 \\
\hline 846D-1H-3, 118 & 7.18 & 7.36 & 0.0 & 0.3 & 0.0 & 0.3 & 1.8 & 0.0 & 0.0 & 327 & 3.6 & 3.8 \\
\hline $846 \mathrm{D}-1 \mathrm{H}-3,128$ & 7.28 & 7.45 & 0.0 & 0.3 & 0.0 & 0.3 & 1.9 & 0.0 & 1.3 & 310 & 2.7 & 3.7 \\
\hline $846 \mathrm{D}-1 \mathrm{H}-3,138$ & 7.38 & 7.54 & 0.0 & 0.0 & 0.0 & 0.0 & 1.7 & 0.0 & 2.9 & 417 & 4.2 & 2.3 \\
\hline $846 \mathrm{D}-1 \mathrm{H}-3,148$ & 7.48 & 7.62 & 0.0 & 0.0 & 0.0 & 0.0 & 2.7 & 0.0 & 2.1 & 337 & 4.8 & 3.7 \\
\hline $846 \mathrm{D}-1 \mathrm{H}-4,8$ & 7.58 & 7.71 & 0.0 & 0.5 & 0.0 & 0.0 & 2.7 & 0.0 & 2.9 & 414 & 5.1 & 3.7 \\
\hline $846 \mathrm{D}-1 \mathrm{H}-4,18$ & 7.68 & 7.79 & 0.0 & 0.0 & 0,0 & 0.2 & 1.7 & 0.0 & 1.5 & 405 & 4.6 & 4.9 \\
\hline $846 \mathrm{D}-1 \mathrm{H}-4,28$ & 7.78 & 7.88 & 0.0 & 0.0 & 0.0 & 0.0 & 2.9 & 0.0 & 2.1 & 241 & 5.1 & 5.5 \\
\hline $846 \mathrm{D}-1 \mathrm{H}-4,38$ & 7.88 & 7.96 & 0.0 & 0.2 & 0.0 & 0.2 & 2.3 & 0.0 & 0.0 & 432 & 2.5 & 3.1 \\
\hline $846 \mathrm{D}-1 \mathrm{H}-4,48$ & 7.98 & 8.03 & 0.0 & 0.9 & 0.0 & 0.0 & 7.7 & 0.0 & 1.8 & 454 & 5.6 & 8.3 \\
\hline $846 \mathrm{D}-1 \mathrm{H}-4,58$ & 8.08 & 8.11 & 0.0 & 0.2 & 0.0 & 0.2 & 3.3 & 0.0 & 1.1 & 547 & 3.4 & 2.7 \\
\hline $846 \mathrm{D}-1 \mathrm{H}-4,68$ & 8.18 & 8.19 & 0.0 & 0.0 & 0.0 & 0.0 & 7.7 & 0.0 & 0.4 & 259 & 6.9 & 7.8 \\
\hline $846 \mathrm{D}-1 \mathrm{H}-4,78$ & 8.28 & 8.26 & 0.0 & 0.0 & 0.0 & 0.0 & 8.7 & 0.0 & 2.9 & 241 & 5.0 & 5.1 \\
\hline $846 \mathrm{D}-1 \mathrm{H}-4,88$ & 8.38 & 8.34 & 0.0 & 0.0 & 0.0 & 0.0 & 9.5 & 0.0 & 2.7 & 548 & 7.2 & 6.5 \\
\hline 846D-1H-4, 98 & 8.48 & 8.42 & 0.0 & 1.1 & 0.0 & 0.0 & 12.2 & 0.0 & 1.9 & 378 & 9.6 & 4.8 \\
\hline 846D-1H-4, 108 & 8.58 & 8.50 & 0.0 & 0.0 & 0.0 & 0.0 & 10.2 & 0.0 & 2.9 & 344 & 6.5 & 2.3 \\
\hline $846 \mathrm{D}-1 \mathrm{H}-4,118$ & 8.68 & 8.59 & 0.0 & 0.0 & 0.0 & 0.0 & 8.0 & 0.0 & 2.1 & 523 & 6.1 & 0.9 \\
\hline 846D-IH-4, 128 & 8.78 & 8.68 & 0.0 & 0.4 & 0.0 & 0.0 & 6.6 & 0.0 & 3.3 & 273 & 7.2 & 8.7 \\
\hline $846 \mathrm{D}-1 \mathrm{H}-4,138$ & 8.88 & 8.77 & 0.0 & 0.0 & 0.0 & 0.0 & 4.7 & 0.0 & 1.0 & 387 & 3.8 & 3.5 \\
\hline $846 \mathrm{D}-1 \mathrm{H}-4,148$ & 8.98 & 8.86 & 0.0 & 0.0 & 0.0 & 0.5 & 5.6 & 0.2 & 2.7 & 414 & 4.5 & 5.3 \\
\hline 846D-IH-5, 8 & 9.08 & 8.97 & 0.0 & 0.0 & 0.0 & 0.2 & 9.3 & 0.0 & 2.5 & 440 & 5.8 & 7.9 \\
\hline
\end{tabular}


APPENDIX (continued).

\begin{tabular}{|c|c|c|c|c|c|c|c|c|c|c|c|c|}
\hline & & Revised & & & & & & ecies & & & & \\
\hline interval (cm) & & (rmcd) & O. uni. & G. rub. & G. ten. & G. sac. & G. aeq. & G. cal. & G. bul. & G. rbs. & N.pa. $\mathbf{R}$ & N. dut. \\
\hline $846 \mathrm{D}-1 \mathrm{H}-5.18$ & 9.18 & 9.08 & 0.0 & 0.7 & 0.0 & 0.7 & 9.3 & 0.0 & 0.9 & 450 & 4.6 & 7.0 \\
\hline $846 \mathrm{D}-1 \mathrm{H}-5.28$ & 9.28 & 9.19 & 0.0 & 0.0 & 0.0 & 0.0 & 8.7 & 0.0 & 0.3 & 286 & 5.6 & 6.5 \\
\hline 846D-1H-5, 38 & 9.38 & 9.29 & 0.2 & 0.2 & 0.0 & 0.0 & 3.5 & 0.0 & 1.1 & 462 & 3.7 & 4.5 \\
\hline $846 \mathrm{D}-1 \mathrm{H}-5,48$ & 9.48 & 9.40 & 0.0 & 0.0 & 0.0 & 0.0 & 6.1 & 0.0 & 1.4 & 278 & 4.3 & 2.5 \\
\hline $846 \mathrm{D}-1 \mathrm{H}-5,58$ & 9.58 & 9.49 & 0.2 & 0.2 & 0.0 & 0.0 & 4.6 & 0.0 & 2.9 & 417 & 4.9 & 2.6 \\
\hline $846 \mathrm{D}-1 \mathrm{H}-5,68$ & 9.68 & 9.59 & 0.0 & 0.3 & 0.0 & 3.6 & 2.8 & 0.0 & 3.8 & 394 & 3.8 & 3.0 \\
\hline $846 \mathrm{D}-1 \mathrm{H}-5,78$ & 9.78 & 9.68 & 0.0 & 0.4 & 0.0 & 1.1 & 2.0 & 0.0 & 1.6 & 548 & 3.4 & 1.6 \\
\hline $846 \mathrm{D}-1 \mathrm{H}-5,88$ & 9.88 & 9.78 & 0.0 & 0.0 & 0.0 & 1.0 & 2.2 & 0.0 & 0.2 & 411 & 2.7 & 1.4 \\
\hline $846 \mathrm{D}-1 \mathrm{H}-5,98$ & 9.98 & 9.87 & 0.0 & 0.0 & 0.0 & 1.9 & 1.6 & 0.0 & 0.7 & 425 & 2.5 & 1.6 \\
\hline $846 \mathrm{D}-1 \mathrm{H}-5,108$ & 10.08 & 9.96 & 0.0 & 0.0 & 0.0 & 2.8 & 4.7 & 0.0 & 0.4 & 253 & 3.6 & 2.7 \\
\hline $846 \mathrm{D}-1 \mathrm{H}-5,118$ & 10.18 & 10.06 & 0.0 & 0.0 & 0.0 & 1.0 & 1.8 & 0.0 & 0.4 & 513 & 3.3 & 1.3 \\
\hline $846 \mathrm{D}-1 \mathrm{H}-5.128$ & 10.28 & 10.16 & 0.0 & 0.0 & 0.0 & 2.1 & 1.3 & 0.0 & 0.0 & 376 & 2.9 & 1.8 \\
\hline $846 \mathrm{D}-1 \mathrm{H}-5,138$ & 10.38 & 10.27 & 0.0 & 0.5 & 0.0 & 0.7 & 0.9 & 0.0 & 0.9 & 436 & 3.2 & 1.8 \\
\hline $846 \mathrm{D}-1 \mathrm{H}-5.148$ & 10.48 & 10.38 & 0.0 & 0.0 & 0.0 & 1.8 & 3.0 & 0.0 & 0.3 & 328 & 3.5 & 3.8 \\
\hline $846 \mathrm{D}-\mathrm{IH}-6.8$ & 10.58 & 10.49 & 0.0 & 0.2 & 0.0 & 1.6 & 1.8 & 0.0 & 0.9 & 443 & 4.8 & 6.1 \\
\hline $846 \mathrm{~B}-2 \mathrm{H}-3,8$ & 10.68 & 10.55 & 0.0 & 0.0 & 0.0 & 0.0 & 1.2 & 0.0 & 1.2 & 338 & 5.0 & 6.1 \\
\hline $846 \mathrm{D}-1 \mathrm{H}-6.18$ & 10.68 & 10.61 & 0.0 & 0.3 & 0.0 & 1.8 & 0.6 & 0.0 & 0.6 & 336 & 4.1 & 6.7 \\
\hline $846 \mathrm{~B}-2 \mathrm{H}-3.19$ & 10.79 & 10.70 & 0.0 & 0.0 & 0.0 & 0.0 & 1.6 & 0.0 & 1.1 & 449 & 4.5 & 2.2 \\
\hline $846 \mathrm{~B}-2 \mathrm{H}-3.29$ & 10.89 & 10.89 & 0.0 & 0.0 & 0.0 & 0.0 & 2.3 & 0.0 & 0.5 & 389 & 7.9 & 7.2 \\
\hline $846 \mathrm{~B}-2 \mathrm{H}-3.38$ & 10.98 & 11.02 & 0.0 & 0.0 & 0.0 & 0.0 & 2.1 & 0.0 & 0.6 & 518 & 7.4 & 3.2 \\
\hline $846 \mathrm{~B}-2 \mathrm{H}-3.48$ & 11.08 & 11.12 & 0.0 & 0.0 & 0.0 & 0.0 & 3.2 & 0.0 & 0.8 & 375 & 7.0 & 6.9 \\
\hline $846 \mathrm{~B}-2 \mathrm{H}-3,58$ & 11.18 & 11.20 & 0.0 & 0.0 & 0.0 & 0.0 & 2.9 & 0.0 & 1.4 & 592 & 8.1 & 3.7 \\
\hline $846 \mathrm{~B}-2 \mathrm{H}-3,68$ & 11.28 & 11.28 & 0.0 & 0.3 & 0.0 & 1.1 & 3.0 & 0.0 & 1.6 & 366 & 7.9 & 4.2 \\
\hline $846 \mathrm{~B}-2 \mathrm{H}-3.77$ & 11.37 & 11.36 & 0.0 & 0.2 & 0.0 & 0.2 & 3.1 & 0.2 & 0.8 & 480 & 8.1 & 5.5 \\
\hline $846 \mathrm{~B}-2 \mathrm{H}-3.88$ & 11.48 & 11.48 & 0.0 & 0.0 & 0.0 & 0.0 & 2.1 & 0.0 & 0.8 & 608 & 4.3 & 1.3 \\
\hline $846 \mathrm{~B}-2 \mathrm{H}-3,96$ & 11.56 & 11.58 & 0.0 & 0.0 & 0.0 & 0.7 & 2.2 & 0.4 & 1.1 & 278 & 4.8 & 2.8 \\
\hline $846 \mathrm{~B}-2 \mathrm{H}-3,107$ & 11.67 & 11.69 & 0.0 & 0.0 & 0.0 & 0.4 & 3.1 & 0.2 & 1.3 & 458 & 4.5 & 2.3 \\
\hline $846 \mathrm{~B}-2 \mathrm{H}-3,118$ & 11.78 & 11.80 & 0.0 & 0.0 & 0.0 & 0.3 & 3.5 & 0.0 & 0.3 & 317 & 6.2 & 3.6 \\
\hline $846 \mathrm{~B}-2 \mathrm{H}-3,128$ & 11.88 & 11.88 & 0.0 & 0.0 & 0.0 & 0.0 & 5.8 & 0.0 & 1.6 & 313 & 8.8 & 5.4 \\
\hline $846 \mathrm{~B}-2 \mathrm{H}-3,137$ & 11.97 & 11.95 & 0.0 & 0.0 & 0.0 & 0.0 & 2.1 & 0.2 & 0.9 & 437 & 6.0 & 3.1 \\
\hline $846 \mathrm{~B}-2 \mathrm{H}-3,148$ & 12.08 & 12.03 & 0.0 & 0.0 & 0.0 & 0.0 & 2.6 & 0.4 & 0.4 & 270 & 7.3 & 5.9 \\
\hline $846 \mathrm{~B}-2 \mathrm{H}-4,3$ & 12.13 & 12.09 & 0.0 & 0.4 & 0.0 & 0.0 & 2.8 & 0.0 & 1.8 & 282 & 5.5 & 3.4 \\
\hline $846 \mathrm{~B}-2 \mathrm{H}-4,13$ & 12.23 & 12.19 & 0.0 & 0.6 & 0.0 & 0.3 & 2.1 & 0.0 & 1.5 & 327 & 5.7 & 3.8 \\
\hline $846 \mathrm{~B}-2 \mathrm{H}-4,23$ & 12.33 & 12.31 & 0.0 & 1.3 & 0.0 & 0.0 & 4.7 & 0.0 & 2.0 & 298 & 7.9 & 5.4 \\
\hline $846 \mathrm{~B}-2 \mathrm{H}-4,31$ & 12.41 & 12.42 & 0.0 & 0.3 & 0.0 & 0.3 & 3.6 & 0.0 & 1.6 & 364 & 9.5 & 3.4 \\
\hline $846 \mathrm{~B}-2 \mathrm{H}-4,41$ & 12.51 & 12.53 & 0.0 & 0.0 & 0.0 & 0.2 & 4.1 & 0.0 & 2.3 & 443 & 15.1 & 6.5 \\
\hline $846 \mathrm{~B}-2 \mathrm{H}-4.54$ & 12.64 & 12.65 & 0.0 & 0.0 & 0.0 & 0.6 & 19.2 & 0.0 & 2.3 & 177 & 22.6 & 6.8 \\
\hline $846 \mathrm{~B}-2 \mathrm{H}-4.54$ & 12.64 & 12.65 & 0.0 & 0.6 & 0.0 & 0.0 & 12.1 & 0.0 & 4.8 & 165 & 26.3 & 7.3 \\
\hline $846 \mathrm{~B}-2 \mathrm{H}-4.62$ & 12.72 & 12.72 & 0.5 & 1.6 & 0.0 & 1.4 & 11.6 & 0.0 & 4.0 & 430 & 21.2 & 5.9 \\
\hline $846 \mathrm{~B}-2 \mathrm{H}-4.73$ & 12.83 & 12.81 & 0.0 & 1.2 & 0.0 & 0.7 & 10.0 & 0.0 & 6.7 & 401 & 10.4 & 2.2 \\
\hline $846 \mathrm{~B}-2 \mathrm{H}-4.87$ & 12.97 & 12.96 & 0.0 & 2.1 & 0.0 & 0.7 & 6.2 & 0.0 & 2.7 & 292 & 4.0 & 1.0 \\
\hline $846 \mathrm{~B}-2 \mathrm{H}-4,95$ & 13.05 & 13.05 & 0.0 & 0.2 & 0.0 & 0.0 & 1.7 & 0.0 & 2.0 & 403 & 5.5 & 1.9 \\
\hline $846 \mathrm{~B}-2 \mathrm{H}-4,106$ & 13.16 & 13.18 & 0.0 & 0.3 & 0.0 & 0.3 & 0.5 & 0.0 & 1.0 & 389 & 6.6 & 3.2 \\
\hline $846 \mathrm{~B}-2 \mathrm{H}-4.117$ & 13.27 & 13.29 & 0.0 & 0.2 & 0.0 & 0.2 & 2.1 & 0.0 & 0.9 & 576 & 4.9 & 1.7 \\
\hline $846 \mathrm{~B}-2 \mathrm{H}-4,126$ & 13.36 & 13.37 & 0.0 & 0.0 & 0.0 & 0.0 & 0.6 & 0.0 & 0.5 & 637 & 4.5 & i.1 \\
\hline $846 \mathrm{~B}-2 \mathrm{H}-4.136$ & 13.46 & 13.46 & 0.0 & 0.0 & 0.0 & 0.0 & 0.9 & 0.0 & 1.3 & 446 & 4.0 & 1.5 \\
\hline $846 \mathrm{~B}-2 \mathrm{H}-4,144$ & 13.54 & 13.54 & 0,0 & 1.0 & 0.0 & 0.0 & 0.6 & 0.0 & 0.3 & 311 & 4.0 & 2.5 \\
\hline $846 \mathrm{C}-2 \mathrm{H}-2.58$ & 13.61 & 13.67 & 0.0 & 0.0 & 0.0 & 0.0 & 1.1 & 0.0 & 0.9 & 331 & 5.7 & 2.4 \\
\hline $846 \mathrm{C}-2 \mathrm{H}-2,68$ & 13.71 & 13.78 & 0.0 & 0.0 & 0.0 & 0.3 & 0.3 & 0.0 & 0.9 & 331 & 5.7 & 2.4 \\
\hline $846 \mathrm{C}-2 \mathrm{H}-2.78$ & 13.81 & 13,86 & 0.0 & 0.3 & 0.0 & 0.0 & 0.3 & 0.0 & 2.1 & 385 & 7.3 & 3.3 \\
\hline $846 \mathrm{C}-2 \mathrm{H}-2,88$ & 13.91 & 13.92 & 0.0 & 0.2 & 0.0 & 0.4 & 0.0 & 0.0 & 1.8 & 504 & 7.1 & 0.8 \\
\hline $846 \mathrm{C}-2 \mathrm{H}-2,98$ & 14.01 & 13.97 & 0.0 & 0.0 & 0.0 & 0.0 & 0.0 & 0.0 & 0.9 & 345 & 7.1 & 0.9 \\
\hline $846 \mathrm{C}-2 \mathrm{H}-2.108$ & 14.11 & 14.03 & 0.0 & 0.0 & 0.0 & 0.0 & 0.5 & 0.0 & 1.9 & 378 & 8.0 & 1.6 \\
\hline $846 \mathrm{C}-2 \mathrm{H}-2,118$ & 14.21 & 14.09 & 0.0 & 0.0 & 0.0 & 0.3 & 0.5 & 0.0 & 0.8 & 382 & 4.9 & 0.8 \\
\hline $846 \mathrm{C}-2 \mathrm{H}-2.128$ & 14.31 & 14.18 & 0.0 & 0.3 & 0.0 & 0.0 & 0.3 & 0.0 & 1.0 & 388 & 10.0 & 4.7 \\
\hline $846 \mathrm{C}-2 \mathrm{H}-2.138$ & 14.41 & 14.29 & 0.0 & 0.3 & 0.0 & 0.3 & 0.0 & 0.0 & 2.0 & 300 & 7.4 & 2.6 \\
\hline $846 \mathrm{C}-2 \mathrm{H}-2.48$ & 14.51 & 14.45 & 0.0 & 0.4 & 0.0 & 0.2 & 0.4 & 0.0 & 0.7 & 566 & 3.5 & 1.6 \\
\hline $846 \mathrm{C}-2 \mathrm{H}-3,8$ & 14.61 & 14.59 & 0.0 & 0.4 & 0.0 & 0.0 & 2.1 & 0.0 & 1.3 & 468 & 10.7 & 6.6 \\
\hline $846 \mathrm{C}-2 \mathrm{H}-3.18$ & 14.71 & 14.69 & 0.0 & 0.4 & 0.0 & 0.0 & 1.6 & 0.0 & 1.6 & 248 & 7.3 & 2.4 \\
\hline $846 \mathrm{C}-2 \mathrm{H}-3,28$ & 14.81 & 14.78 & 0.0 & 1.2 & 0.0 & 0.0 & 0.8 & 0.4 & 4.7 & 258 & 13.9 & 3.4 \\
\hline $846 \mathrm{C}-2 \mathrm{H}-3,38$ & 14.91 & 14.86 & 0.0 & 0.7 & 0.0 & 0.0 & 3.5 & 0.7 & 1.7 & 286 & 13.8 & 7.7 \\
\hline $846 \mathrm{C}-2 \mathrm{H}-3.48$ & 15.01 & 14.95 & 0.0 & 0.5 & 0.0 & 0.3 & 5.0 & 0.3 & 3.2 & 380 & 11,0 & 2.8 \\
\hline $846 \mathrm{C}-2 \mathrm{H}-3.58$ & 15.11 & 15.05 & 0.0 & 0.8 & 0.0 & 0.0 & 5.9 & 0.0 & 2.1 & 376 & 11.9 & 5.5 \\
\hline $846 \mathrm{C}-2 \mathrm{H}-3,68$ & 15.21 & 15.17 & 0.0 & 0.0 & 0.0 & 0.0 & 3.2 & 0.0 & 1.3 & 308 & 13.0 & 3.4 \\
\hline $846 \mathrm{C}-2 \mathrm{H}-3.78$ & 15.31 & 15.31 & 0.0 & 1.7 & 0.0 & 0.0 & 14.0 & 0.0 & 2.1 & 236 & 22.8 & 4.8 \\
\hline $846 \mathrm{C}-2 \mathrm{H}-3.8$ & 15.48 & 15.41 & 0.0 & 0.0 & 0.0 & 0.0 & 32.2 & 0.0 & 1.7 & 177 & 37.4 & 10.2 \\
\hline $846 \mathrm{D}-2 \mathrm{H}-1.88$ & 15.41 & 15.46 & 0.0 & 0.2 & 0.0 & 0.0 & 17.3 & 0.0 & 2.9 & 450 & 21.3 & 9.8 \\
\hline $846 \mathrm{C}-2 \mathrm{H}-3,18$ & 15.58 & 15.52 & 1.1 & 0.0 & 0.0 & 0.0 & 28.4 & 0.0 & 4.9 & 268 & 43.2 & 4.3 \\
\hline $846 \mathrm{D}-2 \mathrm{H}-1,98$ & 15.51 & 15.56 & 0.0 & 0.2 & 0.0 & 0.0 & 36.0 & 0.0 & 4.0 & 403 & 33.2 & 6.7 \\
\hline $846 \mathrm{D}-2 \mathrm{H}-1.28$ & 15.68 & 15.63 & 1.1 & 0.8 & 0.0 & 0.0 & 24.9 & 0.3 & 8.2 & 378 & 26.3 & 3.8 \\
\hline $846 \mathrm{D}-2 \mathrm{H}-1.38$ & 15.78 & 15.74 & 0.0 & 0.2 & 0.0 & 0.0 & 35.7 & 0.4 & 2.7 & 524 & 24.5 & 7.3 \\
\hline $846 \mathrm{D}-2 \mathrm{H}-1.48$ & 15.88 & 15.8 & 0.3 & 1.1 & 0.0 & 0.0 & 28.9 & 1.1 & 2.5 & 367 & 23.9 & 5.4 \\
\hline $846 \mathrm{D}-2 \mathrm{H}-1.58$ & 15.98 & 15.95 & 0.2 & 0.2 & 0.0 & 0.0 & 29.8 & 0.0 & 3.7 & 410 & 26.8 & 7.7 \\
\hline $846 \mathrm{D}-2 \mathrm{H}-1.68$ & 16.08 & 16.06 & 0.5 & 0.5 & 0.0 & 0.0 & 30.1 & 0.0 & 4.9 & 549 & 21.9 & 5.2 \\
\hline $846 \mathrm{D}-2 \mathrm{H}-1.78$ & 16.17 & 16.16 & 0.8 & 1.1 & 0.0 & 0.0 & 26.0 & 00 & 4.8 & 354 & 22.5 & 4.6 \\
\hline $846 \mathrm{D}-2 \mathrm{H}-1,88$ & 16.27 & 16. & 0.4 & 1.7 & 0.0 & 0.0 & 20.5 & 0.0 & 3.9 & 458 & 12.3 & 3.8 \\
\hline $846 \mathrm{D}-2 \mathrm{H}-2.8$ & 16.40 & 16.40 & 0.0 & 0.3 & 0.0 & 0.0 & 7.2 & 0.0 & 3.5 & 374 & 7.0 & 1.3 \\
\hline $846 \mathrm{D}-2 \mathrm{H}-2.18$ & 16.51 & 16.51 & 0.0 & 0.3 & 0.0 & 0.0 & 3.4 & 0.0 & 1.1 & 380 & 5.3 & 1.0 \\
\hline $846 \mathrm{D}-2 \mathrm{H}-2.28$ & 16.60 & 16.60 & 00 & 0.0 & 00 & 0.0 & 1.5 & 00 & 0.7 & 542 & 3.9 & 1.1 \\
\hline $846 \mathrm{D}-2 \mathrm{H}-2.38$ & 16.70 & 16.70 & 0.0 & 0.2 & 0.0 & 0.0 & 0.7 & 0.0 & 1.5 & 588 & 3.2 & 1.0 \\
\hline $846 \mathrm{D}-2 \mathrm{H}-2.48$ & 16.81 & 16.82 & 0.0 & 0.0 & 0.0 & 0.0 & 4.1 & 0.0 & 2.5 & 510 & 5.0 & 1.5 \\
\hline $846 \mathrm{D}-2 \mathrm{H}-2,58$ & 16.90 & 16.91 & 0.0 & 0.0 & 0.0 & 0.0 & 0.3 & 0.0 & 1.9 & 372 & 6.2 & 1.1 \\
\hline $846 \mathrm{D}-2 \mathrm{H}-2.68$ & 17.01 & 17.02 & 0.0 & 0.3 & 0.0 & 0.0 & 0.8 & 0.0 & 0.0 & 377 & 4.1 & 1.0 \\
\hline
\end{tabular}


APPENDIX (continued).

\begin{tabular}{|c|c|c|c|c|c|c|c|c|c|c|c|c|}
\hline \multirow{2}{*}{$\begin{array}{l}\text { Core, section, } \\
\text { interval }(\mathrm{cm})\end{array}$} & \multirow{2}{*}{$\begin{array}{l}\text { Shipboard } \\
\text { composite } \\
\text { depth } \\
\text { (mcd) }\end{array}$} & \multirow{2}{*}{$\begin{array}{c}\text { Revised } \\
\text { composite } \\
\text { depth } \\
\text { (rmcd) }\end{array}$} & \multicolumn{10}{|c|}{ Species } \\
\hline & & & o. uni. & G. rub. & G. ten. & G. sac: & G. aeq. & G. cal. & G. bul. & G. rbs. & N. pa. $\mathrm{R}$ & N. dut. \\
\hline $846 \mathrm{D}-2 \mathrm{H}-2,78$ & 17.10 & 17.10 & 0.0 & 0.0 & 0.0 & 0.0 & 0.3 & 0.0 & 1.6 & 317 & 3.6 & 0.6 \\
\hline $846 \mathrm{D}-2 \mathrm{H}-2,88$ & 17.20 & 17.20 & 0.0 & 0.5 & 0.0 & 0.0 & 1.3 & 0.0 & 0.5 & 371 & 6.2 & 1.6 \\
\hline $846 \mathrm{D}-2 \mathrm{H}-2.98$ & 17.31 & 17.31 & 0.0 & 0.2 & 0.0 & 0.0 & 2.4 & 0.0 & 1.0 & 414 & 4.4 & 1.4 \\
\hline $846 \mathrm{D}-2 \mathrm{H}-2,108$ & 17.40 & 17.40 & 0.0 & 0.2 & 0.0 & 0.0 & 0.9 & 0.0 & 1.0 & 578 & 4.2 & 0.7 \\
\hline $846 \mathrm{D}-2 \mathrm{H}-2,118$ & 17.51 & 17.51 & 0.0 & 0.0 & 0.0 & 0.0 & 1.5 & 0.0 & 1.5 & 275 & 4.3 & 1.1 \\
\hline $846 \mathrm{D}-2 \mathrm{H}-2.128$ & 17.60 & 17.60 & 0.0 & 0.3 & 0.0 & 0.0 & 1.6 & 0.0 & 0.6 & 635 & 4.5 & 1.9 \\
\hline $846 \mathrm{D}-2 \mathrm{H}-2,138$ & 17.70 & 17.70 & 0.0 & 0.0 & 0.0 & 0.0 & 1.8 & 0.0 & 0.7 & 275 & 4.5 & 2.1 \\
\hline $846 \mathrm{D}-2 \mathrm{H}-3,8$ & 17.90 & 17.90 & 0.0 & 0.4 & 0.0 & 0.0 & 4.3 & 0.0 & 3.9 & 485 & 3.5 & 1.2 \\
\hline $846 \mathrm{D}-2 \mathrm{H}-3,18$ & 18.00 & 17.99 & 0.0 & 0.0 & 0.0 & 0.0 & 2.7 & 0.0 & 2.7 & 408 & 5.9 & 1.2 \\
\hline $846 \mathrm{D}-2 \mathrm{H}-3,28$ & 18.10 & 18.10 & 0.0 & 0.0 & 0.0 & 0.0 & 2.5 & 0.0 & 3.7 & 353 & 3.4 & 0.8 \\
\hline $846 \mathrm{D}-2 \mathrm{H}-3,38$ & 18.20 & 18.20 & 0.0 & 0.0 & 0.0 & 0.0 & 1.7 & 0.0 & 1.9 & 515 & 2.2 & 0.2 \\
\hline $846 \mathrm{D}-2 \mathrm{H}-3.48$ & 18.30 & 18.29 & 0.0 & 0.2 & 0.0 & 0.0 & 2.0 & 0.0 & 2.2 & 449 & 2.8 & 1.3 \\
\hline $846 \mathrm{D}-2 \mathrm{H}-3,58$ & 18.40 & 18.40 & 0.0 & 0.2 & 0.0 & 0.0 & 2.0 & 0.0 & 2.2 & 548 & 3.1 & 1.3 \\
\hline $846 \mathrm{D}-2 \mathrm{H}-3,68$ & 18.50 & 18.50 & 0.0 & 0.0 & 0.0 & 0.0 & 3.7 & 0.0 & 1.7 & 574 & 3.4 & 1.0 \\
\hline $846 \mathrm{D}-2 \mathrm{H}-3,78$ & 18.60 & 18.60 & 0.0 & 0.0 & 0.0 & 0.0 & 2.4 & 0.0 & 0.9 & 331 & 3.7 & 2.4 \\
\hline $846 \mathrm{D}-2 \mathrm{H}-3,88$ & 18.70 & 18.70 & 0.0 & 0.0 & 0.0 & 0.0 & 6.9 & 0.0 & 2.2 & 492 & 4.5 & 1.4 \\
\hline $846 \mathrm{D}-2 \mathrm{H}-3,98$ & 18.80 & 18.80 & 0.0 & 0.0 & 0.0 & 0.0 & 17.1 & 0.0 & 5.9 & 426 & 14.4 & 3.4 \\
\hline $846 \mathrm{D}-2 \mathrm{H}-3,108$ & 18.90 & 18.90 & 0.0 & 0.3 & 0.0 & 0.0 & 15.1 & 0.0 & 5.0 & 357 & 14.7 & 6.5 \\
\hline $846 \mathrm{D}-2 \mathrm{H}-4,8$ & 19.04 & 19.04 & 0.0 & 0.2 & 0.0 & 0.0 & 13.2 & 0.0 & 2.7 & 630 & 17.1 & 8.2 \\
\hline $846 \mathrm{D}-2 \mathrm{H}-4,18$ & 19.14 & 19.14 & 0.0 & 0.6 & 0.0 & 0.3 & 15.1 & 0.0 & 2.0 & 344 & 20.5 & 4.7 \\
\hline $846 \mathrm{D}-2 \mathrm{H}-4,28$ & 19.24 & 19.24 & 0.0 & 0.0 & 0.0 & 2.6 & 19.4 & 0.0 & 3.6 & 386 & 21.5 & 2.3 \\
\hline $846 \mathrm{D}-2 \mathrm{H}-4,38$ & 19.35 & 19.35 & 0.0 & 0.0 & 0.0 & 0.2 & 14.2 & 0.0 & 2.7 & 402 & 10.9 & 3.8 \\
\hline $846 \mathrm{D}-2 \mathrm{H}-4,48$ & 19.44 & 19.44 & 0.0 & 0.4 & 0.0 & 0.0 & 23.7 & 0.0 & 2.0 & 249 & 17.9 & 2.7 \\
\hline $846 \mathrm{D}-2 \mathrm{H}-4,58$ & 19.54 & 19.54 & 0.0 & 0.4 & 0.0 & 0.0 & 22.6 & 0.0 & 5.5 & 508 & 15.4 & 3.6 \\
\hline $846 \mathrm{D}-2 \mathrm{H}-4,68$ & 19.64 & 19.64 & 0.5 & 1.6 & 0.0 & 0.0 & 21.8 & 0.0 & 5.8 & 380 & 16.0 & 6.2 \\
\hline $846 \mathrm{D}-2 \mathrm{H}-4,78$ & 19.74 & 19.74 & 0.5 & 0.0 & 0.0 & 0.0 & 18.3 & 0.0 & 2.6 & 427 & 14.5 & 6.8 \\
\hline $846 \mathrm{D}-2 \mathrm{H}-4,88$ & 19.85 & 19.85 & 0.0 & 0.0 & 0.0 & 0.0 & 15.7 & 0.0 & 4.1 & 293 & 13.3 & 5.5 \\
\hline $846 \mathrm{D}-2 \mathrm{H}-4,98$ & 19.94 & 19.94 & 0.0 & 1.1 & 0.0 & 0.0 & 12.4 & 0.0 & 5.2 & 458 & 19.0 & 6.0 \\
\hline $846 \mathrm{D}-2 \mathrm{H}-4,108$ & 20.04 & 20.04 & 0.0 & 0.0 & 0.0 & 0.0 & 12.1 & 0.0 & 4.5 & 313 & 14.2 & 5.7 \\
\hline $846 \mathrm{~B}-3 \mathrm{H}-2,8$ & 20.13 & 20.27 & 0.0 & 0.3 & 0.0 & 0.0 & 8.9 & 0.0 & 1.9 & 617 & 10.4 & 1.9 \\
\hline $846 \mathrm{~B}-3 \mathrm{H}-2,18$ & 20.22 & 20.35 & 0.0 & 0.0 & 0.0 & 0.0 & 3.6 & 0.0 & 2.7 & 414 & 6.5 & 2.4 \\
\hline $846 \mathrm{~B}-3 \mathrm{H}-2,27$ & 20.31 & 20.42 & 0.0 & 0.0 & 0.0 & 0.0 & 3.2 & 0.6 & 4.7 & 342 & 6.3 & 1.7 \\
\hline $846 \mathrm{~B}-3 \mathrm{H}-2,37$ & 20.42 & 20.51 & 0.0 & 0.9 & 0.0 & 0.2 & 3.5 & 0.0 & 1.7 & 460 & 5.1 & 1.5 \\
\hline $846 \mathrm{~B}-3 \mathrm{H}-2,48$ & 20.53 & 20.60 & 0.0 & 0.0 & 0.0 & 0.0 & 2.0 & 0.0 & 1.2 & 509 & 4.2 & 1.5 \\
\hline $846 \mathrm{~B}-3 \mathrm{H}-2,58$ & 20.63 & 20.70 & 0.0 & 0.0 & 0.0 & 0.0 & 1.0 & 0.0 & 1.8 & 601 & 4.0 & 1.2 \\
\hline $846 \mathrm{~B}-3 \mathrm{H}-2,69$ & 20.74 & 20.81 & 0.0 & 0.3 & 0.0 & 0.0 & 0.6 & 0.0 & 1.8 & 339 & 3.2 & 1.2 \\
\hline $846 \mathrm{~B}-3 \mathrm{H}-2,78$ & 20.84 & 20.92 & 0.0 & 0.0 & 0.0 & 0.0 & 1.7 & 0.0 & 1.7 & 471 & 2.7 & 0.8 \\
\hline $846 \mathrm{~B}-3 \mathrm{H}-2,88$ & 20.93 & 21.04 & 0.0 & 0.0 & 0.0 & 0.0 & 1.8 & 0.0 & 1.3 & 453 & 2.8 & 1.1 \\
\hline $846 \mathrm{~B}-3 \mathrm{H}-2,109$ & 21.14 & 21.35 & 0.0 & 0.3 & 0.3 & 0.0 & 2.0 & 0.0 & 2.0 & 300 & 7.3 & 3.5 \\
\hline $846 \mathrm{~B}-3 \mathrm{H}-2,128$ & 21.33 & 21.56 & 0.0 & 0.0 & 0.0 & 0.2 & 2.7 & 0.0 & 3.0 & 402 & 5.8 & 4.1 \\
\hline $846 \mathrm{~B}-3 \mathrm{H}-2,147$ & 21.52 & 21.68 & 0.0 & 0.0 & 0.0 & 0.0 & 5.1 & 0.0 & 0.8 & 370 & 6.5 & 4.6 \\
\hline $846 \mathrm{~B}-3 \mathrm{H}-3,18$ & 21.73 & 21.83 & 0.3 & 0.7 & 0.0 & 0.0 & 7.7 & 0.0 & 1.4 & 287 & 16.8 & 8.0 \\
\hline $846 \mathrm{~B}-3 \mathrm{H}-3,36$ & 21.90 & 21.99 & 0.0 & 0.6 & 0.0 & 0.0 & 9.7 & 0.0 & 4.9 & 309 & 20.5 & 3.1 \\
\hline $846 \mathrm{~B}-3 \mathrm{H}-3,58$ & 22.13 & 22.26 & 0.3 & 0.5 & 0.0 & 6.3 & 4.2 & 0.0 & 2.9 & 380 & 7.5 & 4.8 \\
\hline $846 \mathrm{~B}-3 \mathrm{H}-3,77$ & 22.32 & 22.49 & 0.2 & 0.4 & 0.0 & 5.1 & 3.9 & 0.0 & 3.5 & 570 & 10.2 & 5.0 \\
\hline $846 \mathrm{~B}-3 \mathrm{H}-3,99$ & 22.54 & 22.71 & 0.0 & 0.0 & 0.0 & 0.8 & 7.7 & 0.0 & 4.6 & 260 & 11.6 & 5.1 \\
\hline $846 \mathrm{~B}-3 \mathrm{H}-3,118$ & 22.73 & 22.87 & 0.0 & 1.3 & 0.0 & 0.0 & 28.6 & 0.0 & 1.7 & 231 & 13.9 & 12.8 \\
\hline $846 \mathrm{~B}-3 \mathrm{H}-3,137$ & 22.92 & 23.02 & 0.2 & 0.8 & 0.0 & 0.2 & 15.6 & 0.0 & 5.5 & 507 & 20.1 & 4.0 \\
\hline $846 \mathrm{~B}-3 \mathrm{H}-4,3$ & 23.08 & 23.14 & 0.0 & 2.4 & 0.0 & 0.0 & 8.6 & 0.0 & 5.4 & 467 & 6.9 & 0.8 \\
\hline $846 \mathrm{~B}-3 \mathrm{H}-4,23$ & 23.28 & 23.30 & 0.2 & 1.2 & 0.0 & 0.2 & 4.8 & 0.0 & 3.0 & 568 & 5.8 & 2.1 \\
\hline $846 \mathrm{~B}-3 \mathrm{H}-4,44$ & 23.49 & 23.48 & 0.0 & 0.4 & 0.0 & 2.1 & 1.8 & 0.0 & 4.1 & 512 & 5.3 & 1.5 \\
\hline $846 \mathrm{~B}-3 \mathrm{H}-4,62$ & 23.67 & 23.65 & 0.3 & 0.0 & 0.0 & 3.9 & 1.8 & 0.0 & 2.1 & 388 & 3.8 & 2.0 \\
\hline $846 \mathrm{~B}-3 \mathrm{H}-4,79$ & 23.84 & 23.83 & 0.2 & 0.7 & 0.0 & 2.7 & 2.0 & 0.0 & 3.7 & 591 & 4.8 & 2.3 \\
\hline $846 \mathrm{~B}-3 \mathrm{H}-4,103$ & 24.08 & 24.08 & 0.0 & 1.0 & 0.0 & 3.2 & 2.3 & 0.0 & 1.9 & 311 & 7.6 & 6.9 \\
\hline $846 \mathrm{~B}-3 \mathrm{H}-4,125$ & 24.30 & 24.30 & 0.0 & 0.6 & 27.8 & 1.3 & 3.1 & 0.0 & 1.7 & 478 & 7.1 & 3.4 \\
\hline $846 \mathrm{~B}-3 \mathrm{H}-4,145$ & 24.49 & 24.48 & 0.0 & 1.1 & 13.7 & 2.5 & 1.1 & 0.0 & 3.2 & 285 & 7.4 & 3.7 \\
\hline $846 \mathrm{~B}-3 \mathrm{H}-5,18$ & 24.73 & 24.71 & 0.0 & 0.2 & 1.6 & 1.6 & 2.2 & 0.0 & 4.3 & 489 & 4.5 & 1.6 \\
\hline $846 \mathrm{D}-3 \mathrm{H}-1,48$ & 25.17 & 25.07 & 0.0 & 0.4 & 0.0 & 1.6 & 0.8 & 0.0 & 3.8 & 494 & 4.7 & 6.8 \\
\hline $846 \mathrm{D}-3 \mathrm{H}-\mathrm{I}, 68$ & 25.37 & 25.30 & 0.0 & 0.0 & 12.8 & 0.4 & 5.2 & 0.0 & 2.4 & 250 & 10.4 & 9.7 \\
\hline $846 \mathrm{D}-3 \mathrm{H}-1,88$ & 25.58 & 25.42 & 0.0 & 0.0 & 24.6 & 1.4 & 4.3 & 0.0 & 4.3 & 423 & 9.2 & 5.8 \\
\hline $846 \mathrm{D}-3 \mathrm{H}-1,108$ & 25.78 & 25.48 & 0.0 & 0.8 & 6.5 & 0.8 & 0.8 & 0.0 & 1.9 & 261 & 11.3 & 5.4 \\
\hline $846 \mathrm{D}-3 \mathrm{H}-\mathrm{I}, 128$ & 25.98 & 25.54 & 0.0 & 0.3 & 4.0 & 0.0 & 3.2 & 0.0 & 4.0 & 347 & 8.1 & 3.6 \\
\hline $846 \mathrm{D}-3 \mathrm{H}-1,148$ & 26.17 & 25.69 & 0.0 & 1.1 & 0.0 & 1.6 & 10.2 & 0.0 & 4.9 & 450 & 12.9 & 5.9 \\
\hline $846 \mathrm{D}-3 \mathrm{H}-2,18$ & 26.37 & 26.21 & 0.0 & 1.2 & 0.3 & 0.0 & 6.7 & 0.0 & 4.7 & 344 & 7.2 & 5.8 \\
\hline $846 \mathrm{D}-3 \mathrm{H}-2,48$ & 26.67 & 26.46 & 0.0 & 1.3 & 0.4 & 0.0 & 1.7 & 0.0 & 1.3 & 230 & 7.4 & 8.0 \\
\hline
\end{tabular}

